\title{
خطاب النصر في القرآن الكريم في ضوء المعايير الخارجية للأداء النصيّ
}

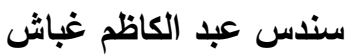

\author{
أ.م.د علي حسن عبد الحسين الالفي \\ جامعة واسط كلية التربية
}

توطئة:

في مفهوم (الخطاب، النَّصَ، النَّصر)

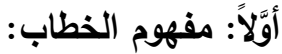

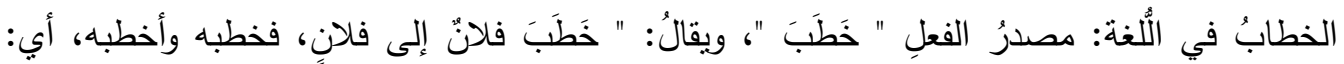

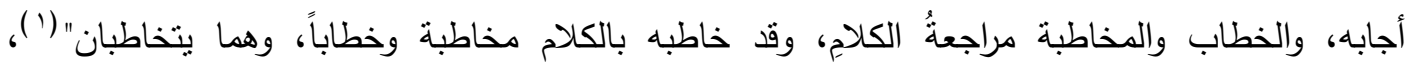

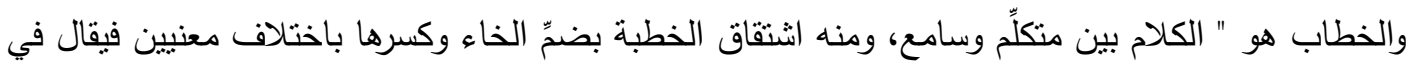
الموعظة: خطب القوم وعليهم من باب قتل بالضَّمٍ وهي فُعُلة بمعنى مفعولة نحو: نُسنْة بمعنى منسوخة

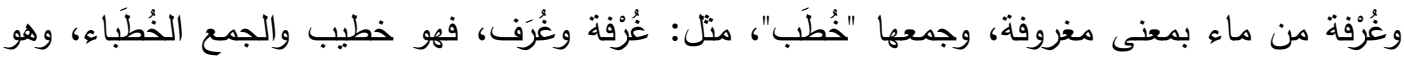

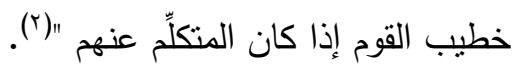

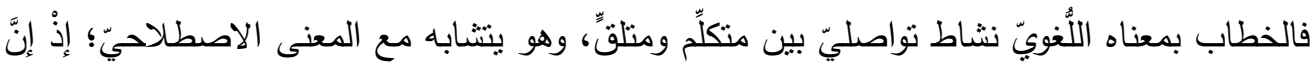

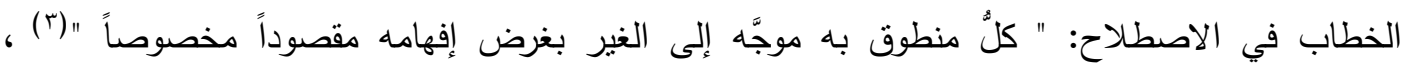

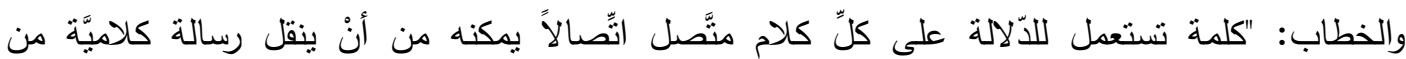

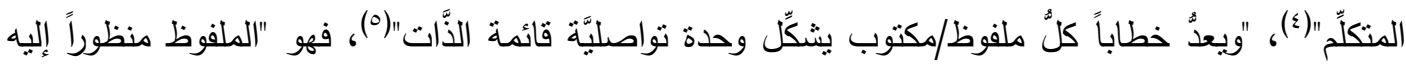

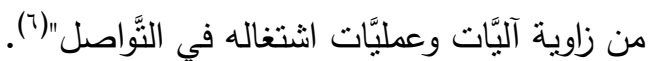
من هذه النَّعريفات يمكننا استقصاء ثلاثئة أمور :

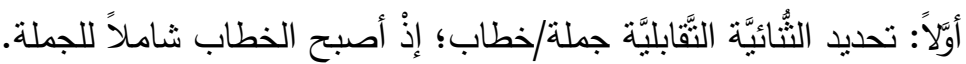
ثانياً: اعتماد النَّاصليَّة معياراً للخطابيَّة.

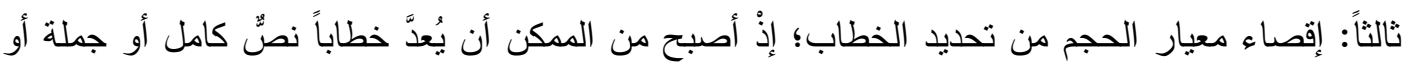




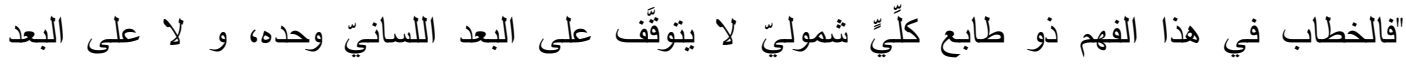

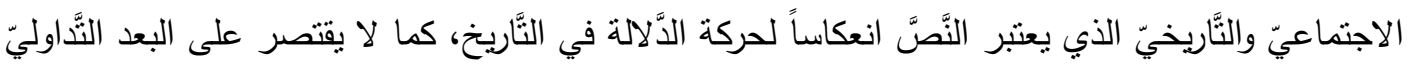

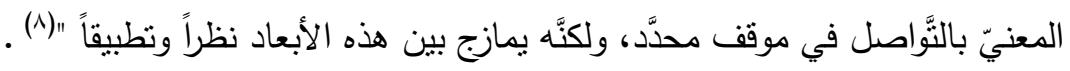

ثانياً: مفهوم النَّصِّ:

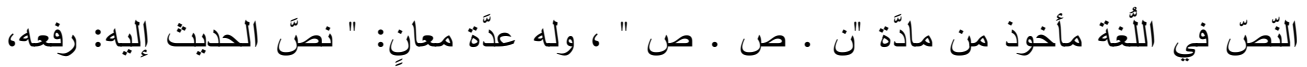

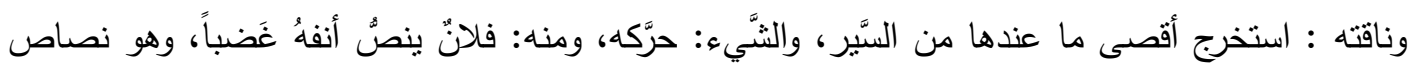

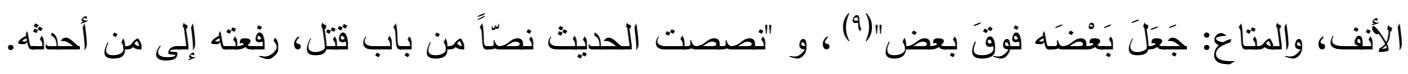

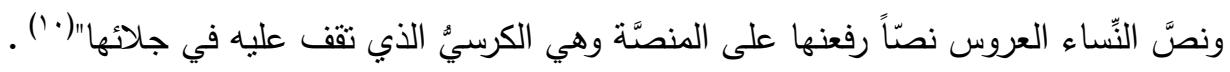

أمَّا النَّصُّ في الاصطلاح فقد تباينت نظرة الباحثنين له، فمنهم من يرى أنَّ النَّصَّ كلّ خطاب نمَّ تنثيته

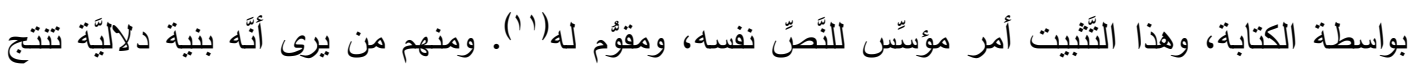
ضمن بنية نصيَّةَّة منتجة في إطار بنية أوسع، وهذه البنية مرتبطة بالسيّاق (الاجتماعي والتَّاريخي

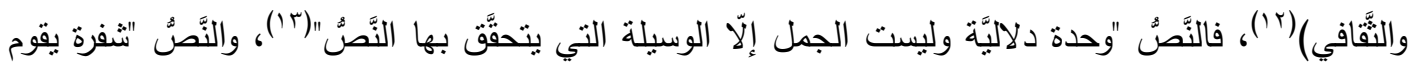

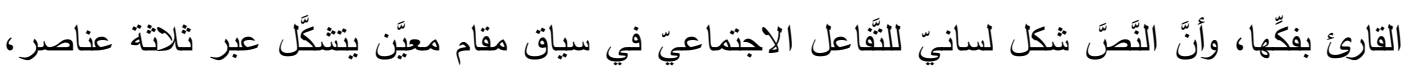

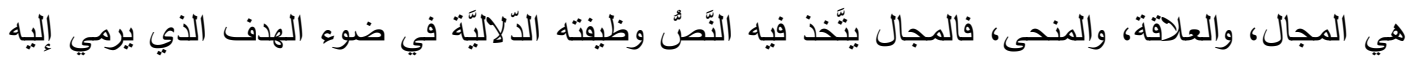

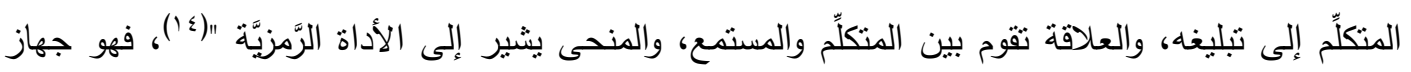

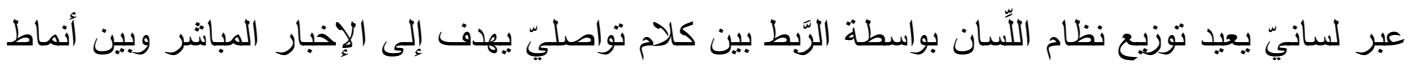

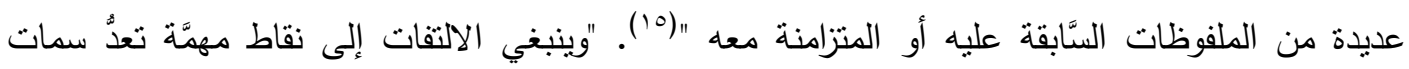

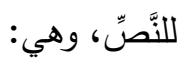




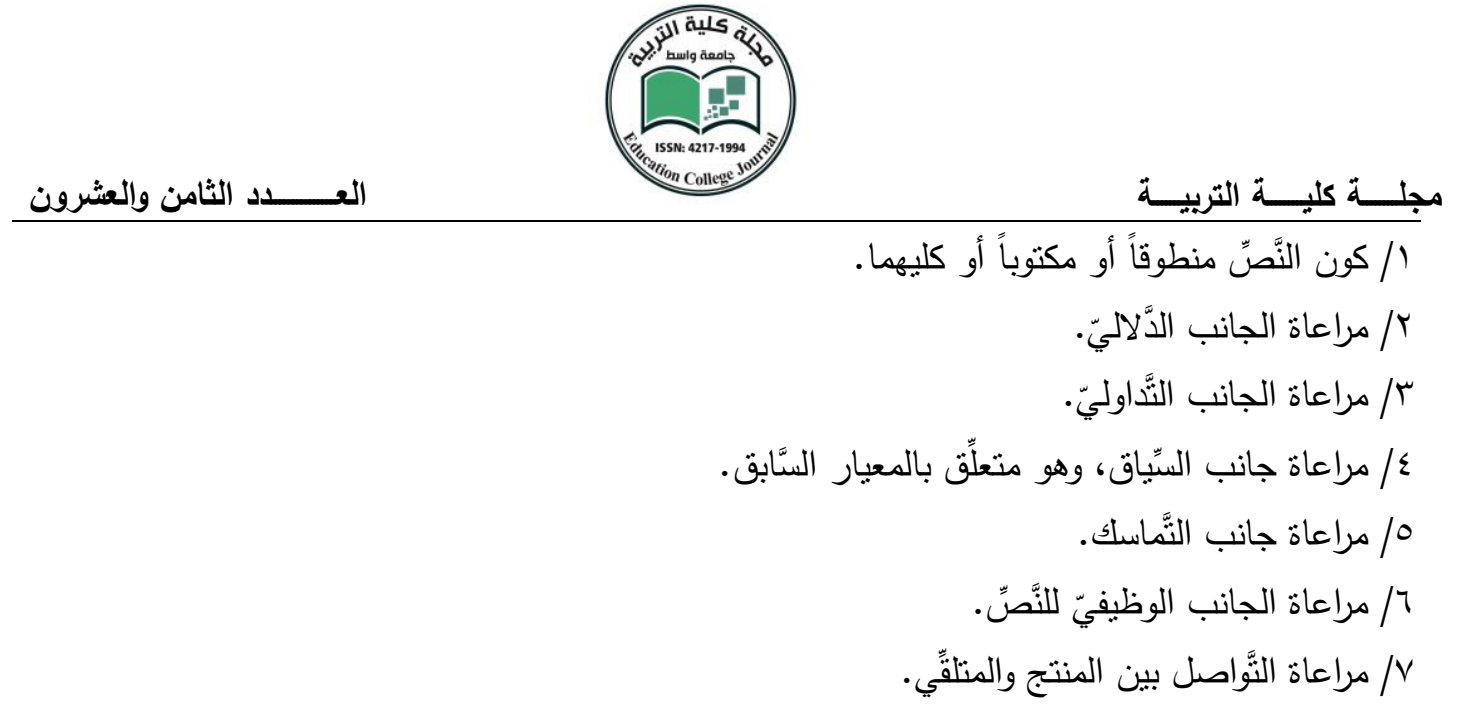

وتعدُ هذه المعايير سمات للنَّصِّ الكامل، وإذا اختلَّت سمة من هذه السِّات بمكن أن نطلق على النَّصِّ نصيّاً ناقصاً "(17) (17).

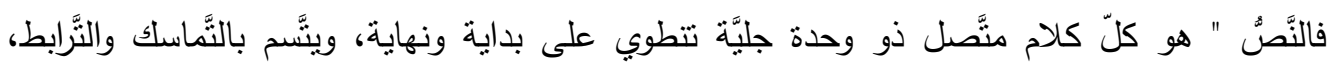

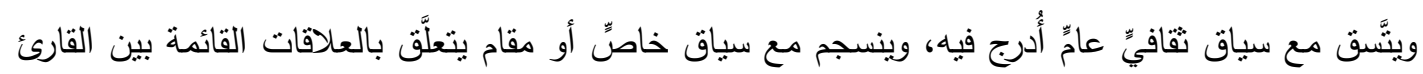

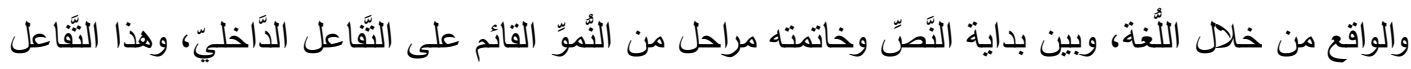

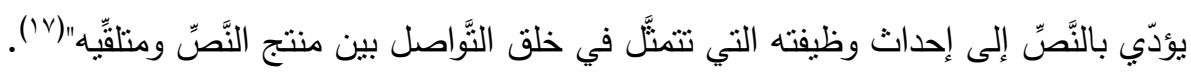

ومن خلال تعريف الخطاب، وتعريف النَّصِّ، نلحظ أنَّ " الخطاب مجموعة من النُصوص ذات

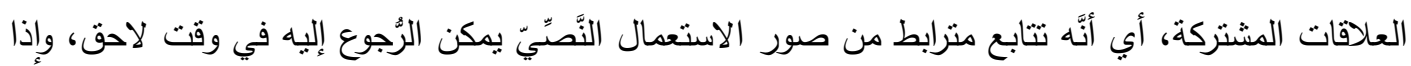

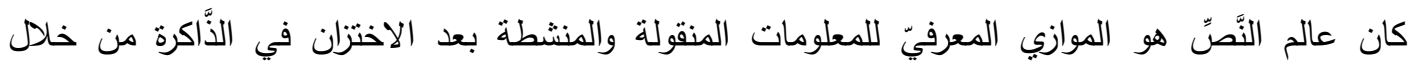

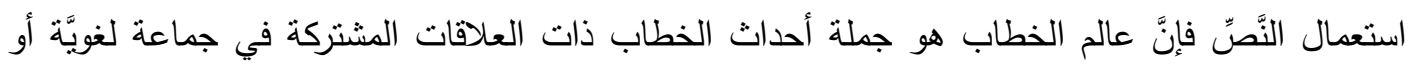

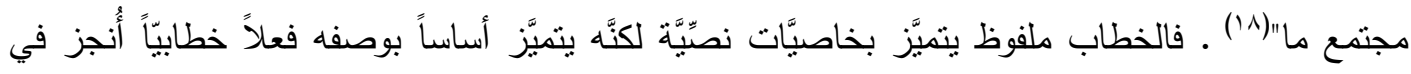

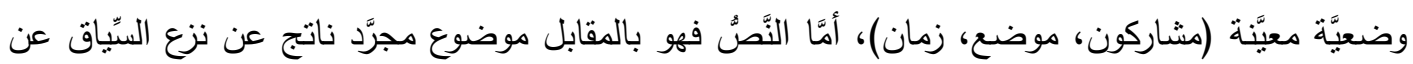

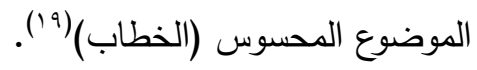




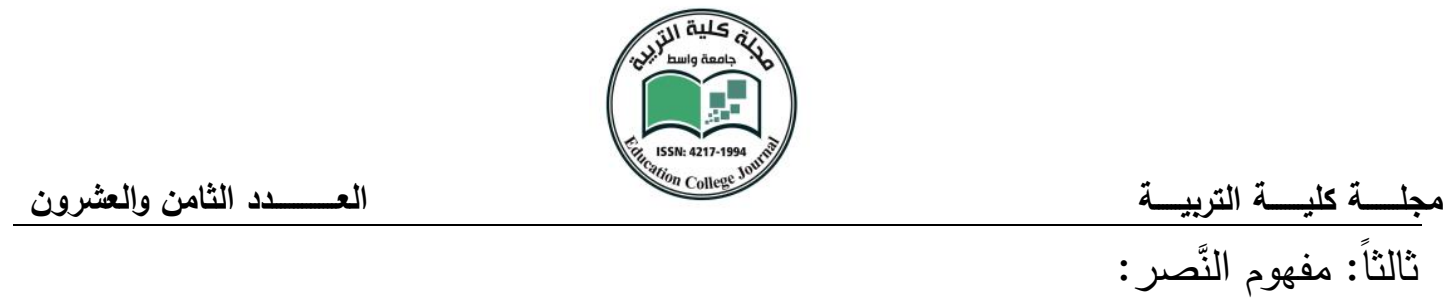

النَّصر في اللُّة: " النُّن والصَّاد والرَّاء أصل صحيح، يدلٌ على إتبان الخير وإينائه، ونصر الهه

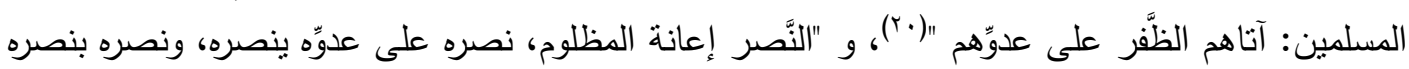

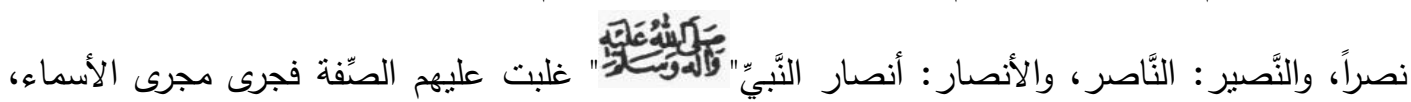

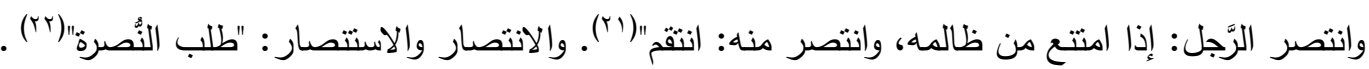

وجاءت لفظة النَّصر في القرآن الكريم باشنقاقات وصيخ متعدّدة بلغت مئة وثمان وخمسين مرَّة ـ أمَّا

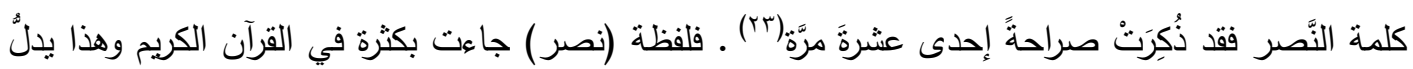

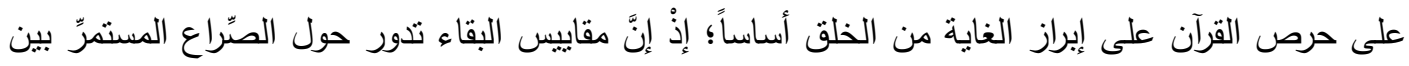

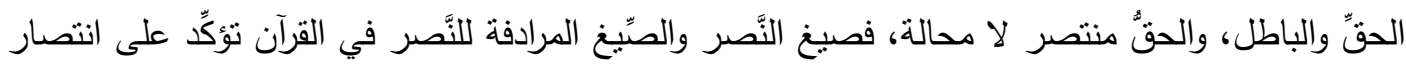

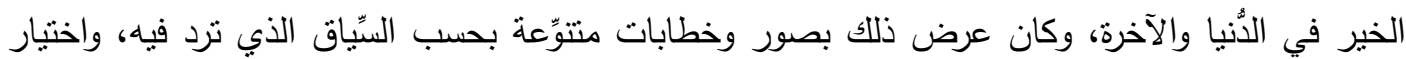

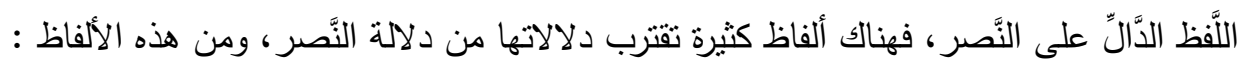

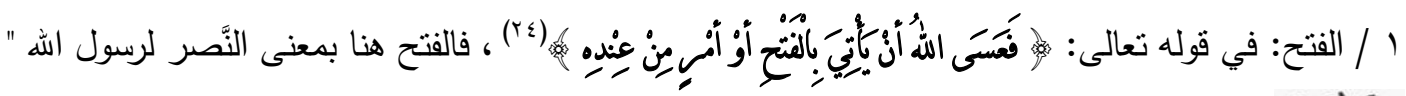
ب

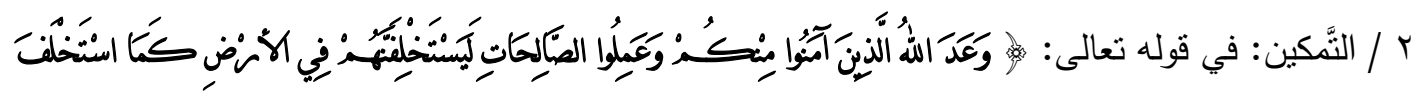

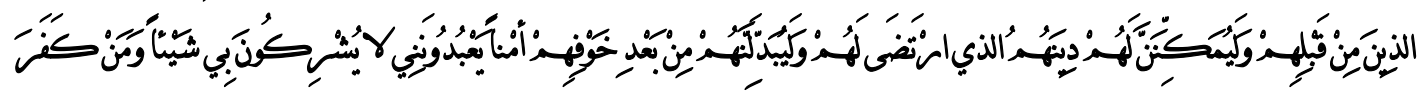

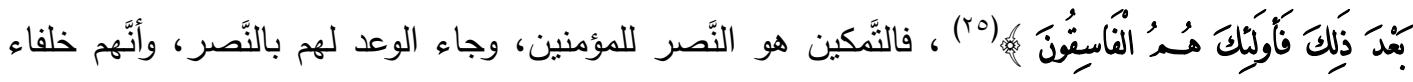
الأرض، وهم الآمنون بعد خوفهم بشرط ألّا يكفروا، فمن كفر فهو فاسق مُبعد من رحمة الله.

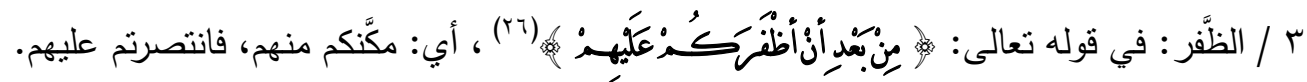

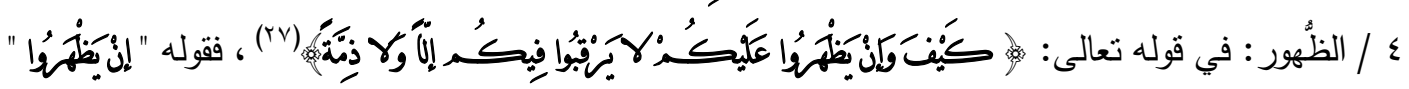

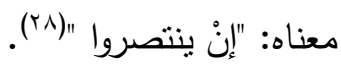




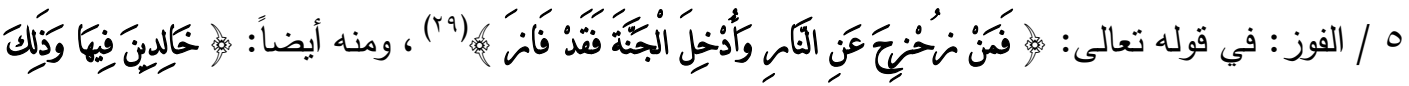

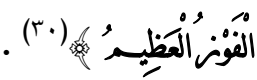

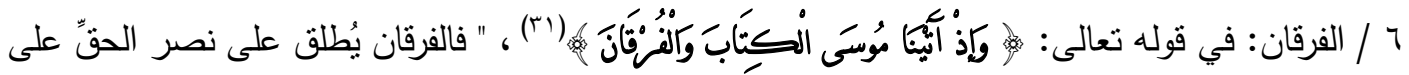

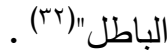

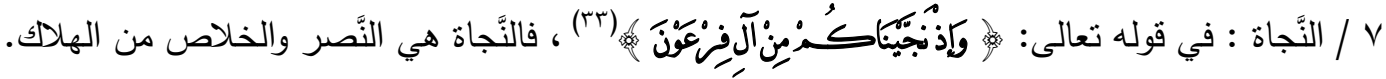

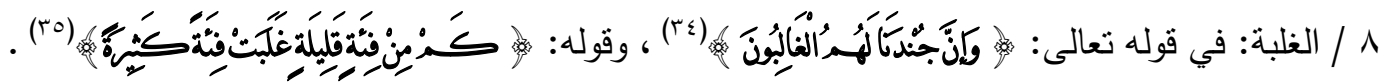
فهذه هي أبرز الألفاظ التي تدلُ على النَّصر في القرآن الكريم ، وكلُ لفظ جاء متتاسقاً مع الغرض الذي سيق له، منوافقاً مع الألفاظ الأخرى التي ترد في سياق النَّصِّ.

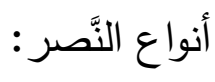

أنواع النَّصر : " هي الطُرق والكيفيَّات التي يتحقَّق بها نصر الله لرسله وأوليائه على أعدائهم، وقد بظنُّ

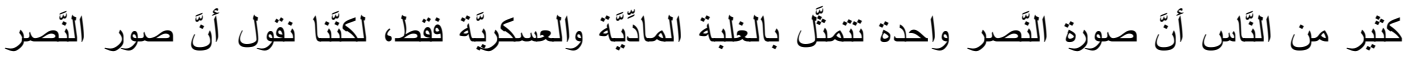

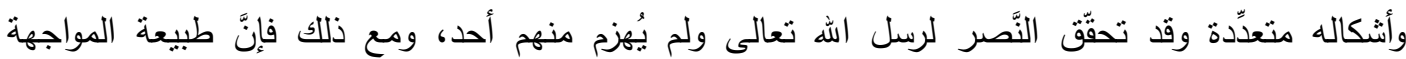

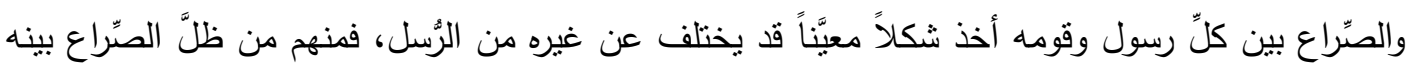

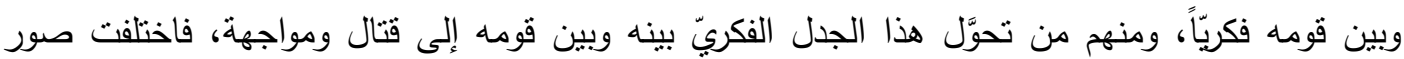

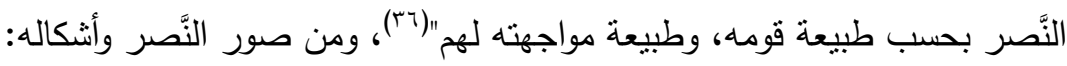

1 / النَّصر بالغلبة مباشرة، وقهر الأعداء على أيدي الأنبياء والرُّل، وهذا النَّوع من النَّصر هو النَّصر

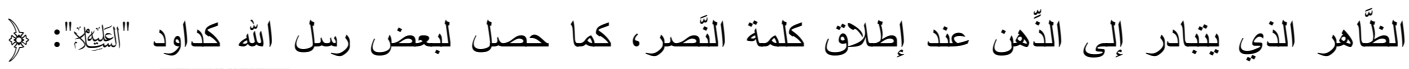

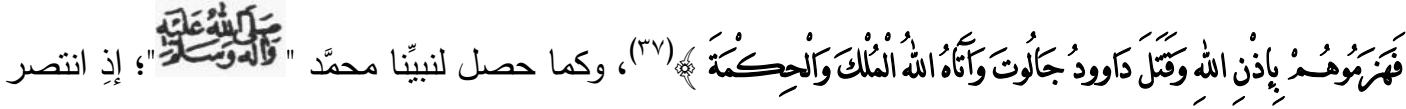

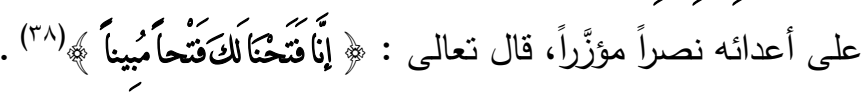


r / النَّصر بإهلاك المكنِّين ونجاة الأنبياء والمرسلين ومن آمن معهم، كما حصل لكثير من الأنبياء، مثل

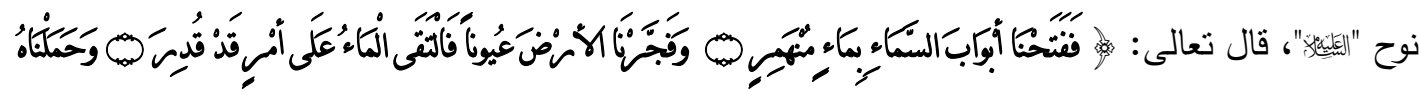

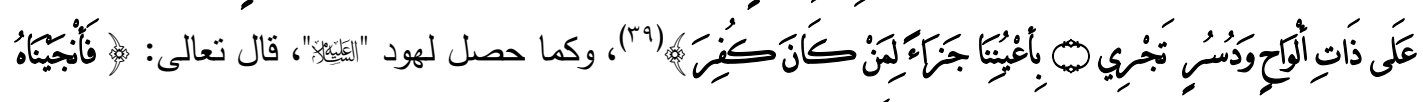

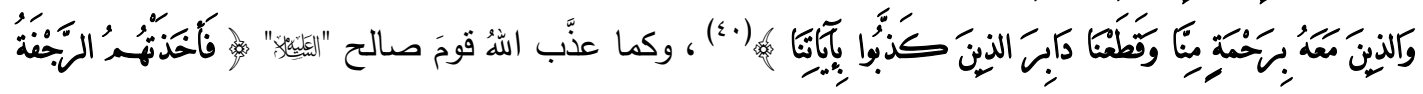

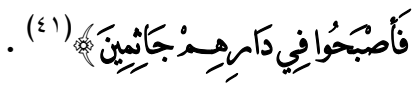

r / النَّصر بثبات الََّّاعية على مبدئه: وهذا النََّع من النَّصر يكون بعد محاولات متتالية من الأعداء لإرغام

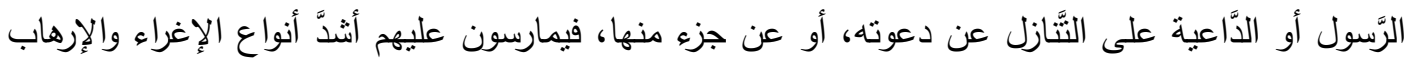

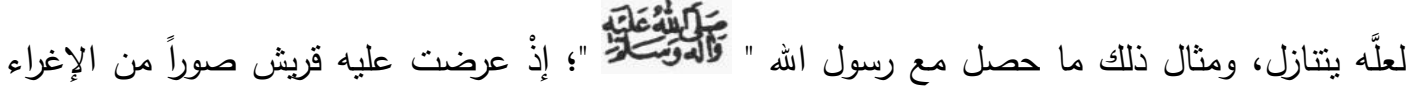

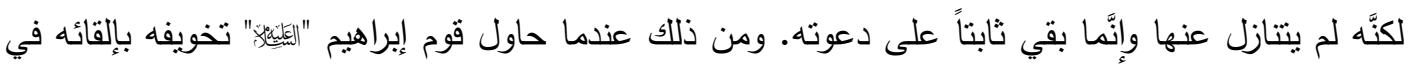

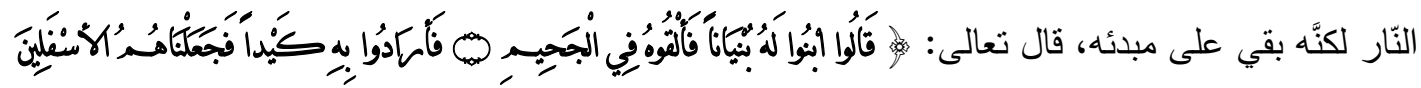

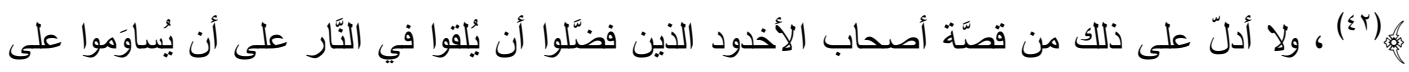

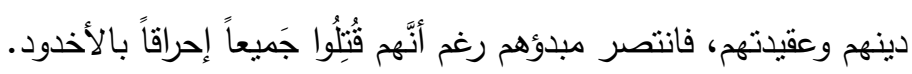

ـ / النَّصر بقوَّة الحجَّة والبرهان: صورة من صور النَّصر تكون بعد جدال عقليّ بين الرُّول أو الدَّاعية

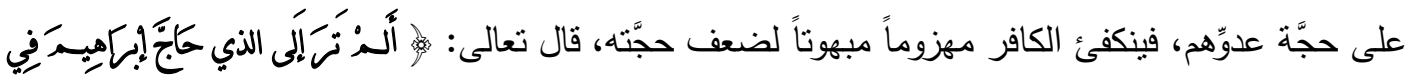

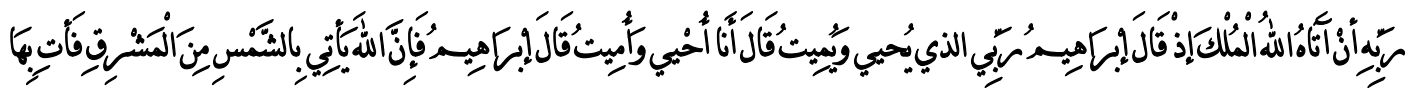

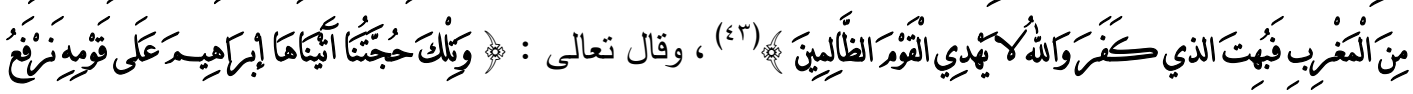

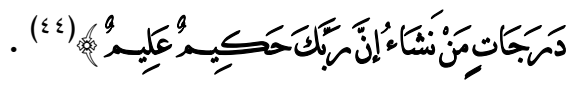

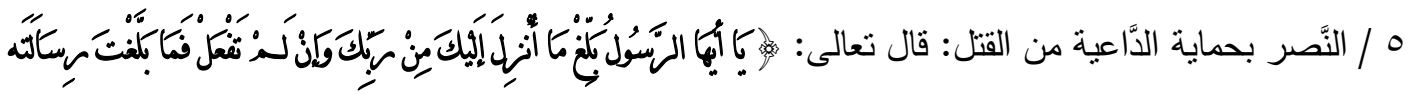

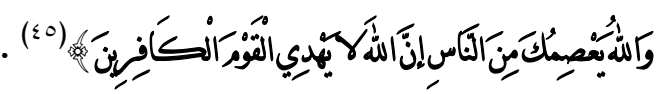


وهكذا نرى أنَّ صور النَّصر وأثنكاله متعدِّة، تتحقَّق بصور وكيفِّات متنوّعة بحسب طبيعة القوم، وطبيعة الزَّمان، وطبيعة المواجهة التي تقع بين أصحاب الرّّالات و أعدائهر .

مقوِّمات النَّصر : n n

للنَّصر مقوّمات كثيرة ومتعدِّة، منها:

/ الإيمان: ويُعدُ أبرز مقوّمات النَّصر ؛ لهذا قدَّم سبحانه الإيمان على العمل الصَّالح في آية الاستخلاف،

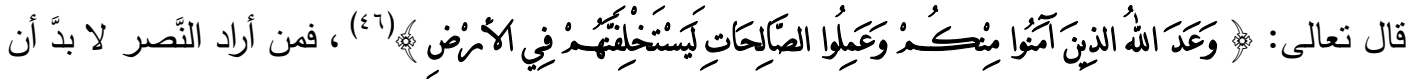

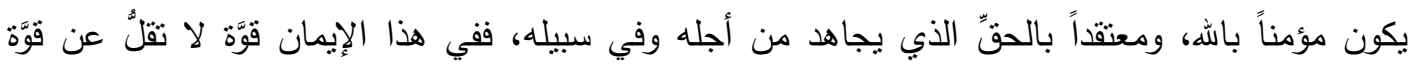

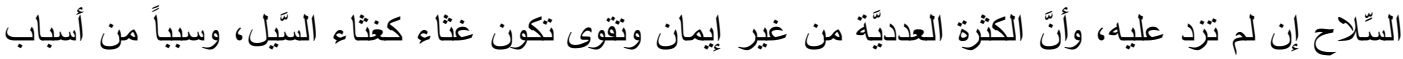

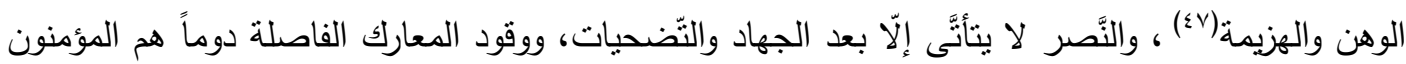

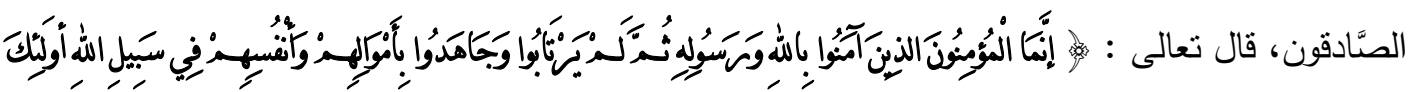

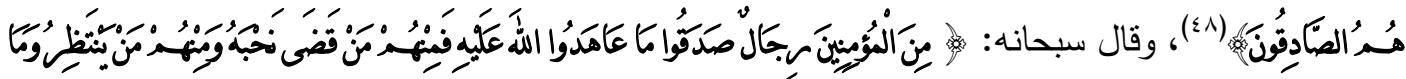

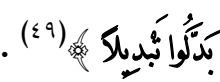

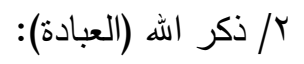

العبادة شرط أساسيّ من شروط تحقُق النَّصر سواء في الدُنيا أم في الآخرة، فالعبادة هي الغاية

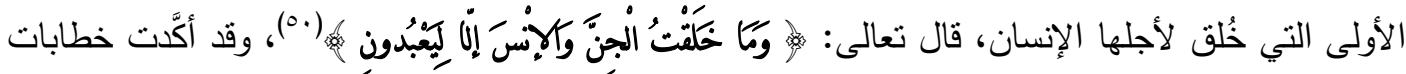

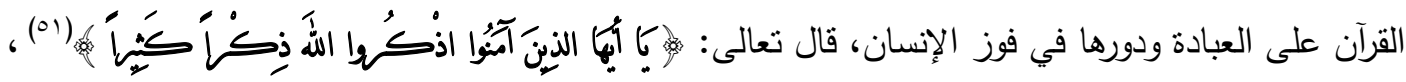

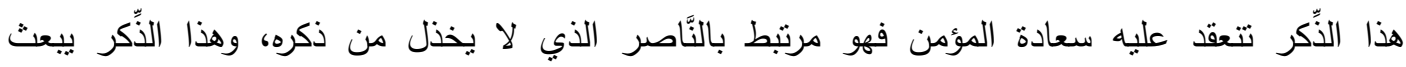

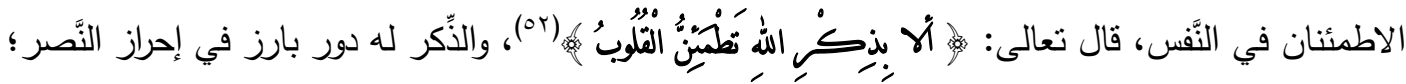

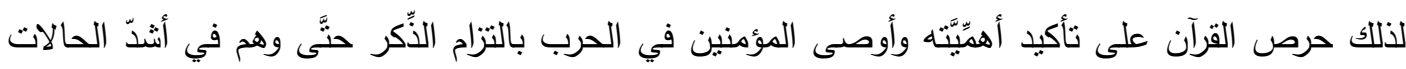

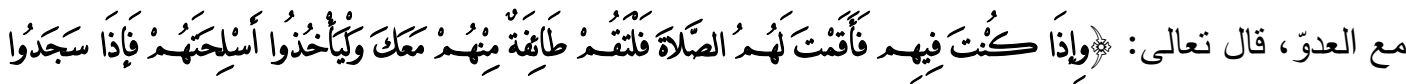




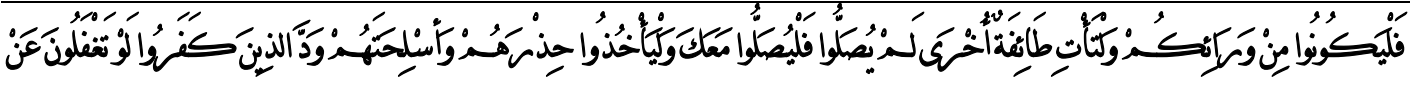

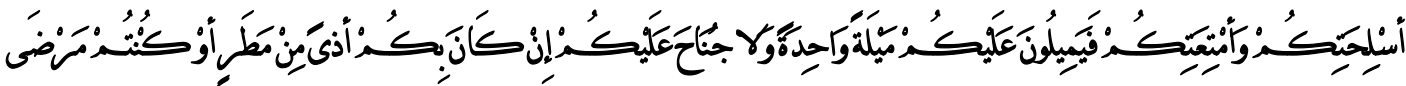

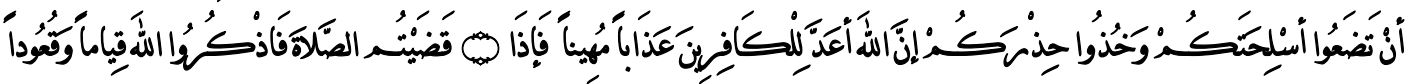

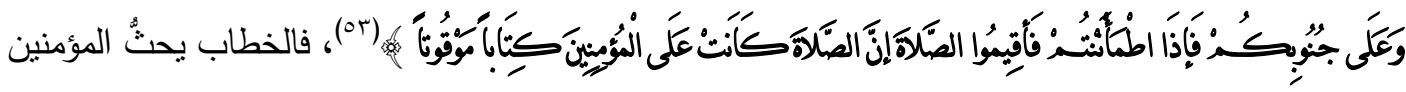

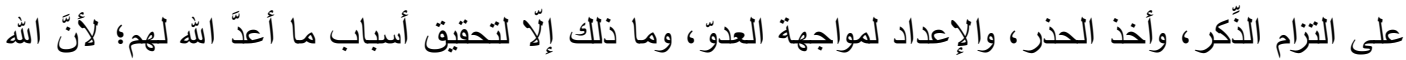

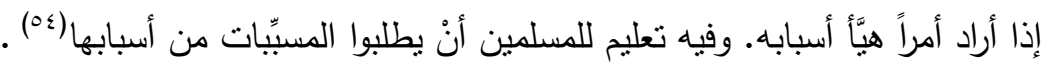

r /الإعداد للحرب: هذا العامل مهُّ جدًا لتحقيق النَّصر وهو يستلزم تحشيد الطَّاقات في سبيل الغاية

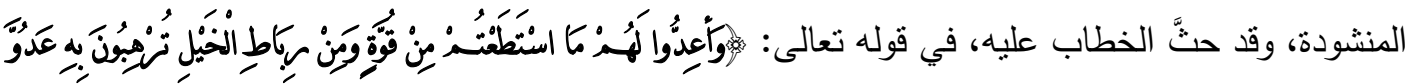

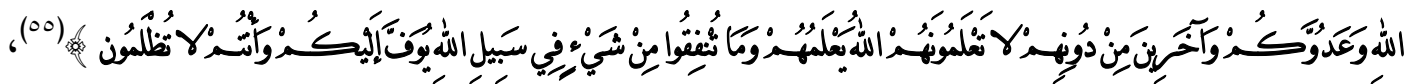

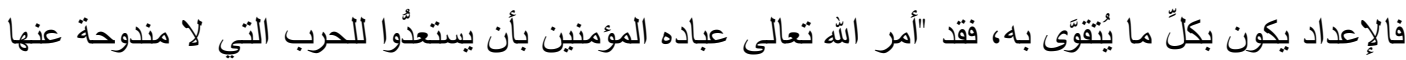
لافع العدوان والثُرِّر، ولحفظ الأنفس، ورعاية الحقِّ والعدل والأمن والفضيلة بأمرين:

$$
\text { | } 1 \text { / إعداد جميع أسباب القوَّة وحثدها بقدر الاسنطاعة. }
$$

r / مرابطة جيوشهم في ثغور بلادهم وحدودها، وهي مداخل الأعداء ومواضع مهاجمنهم للبلاد، والمراد أنْ

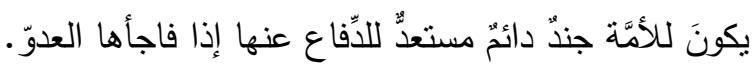

وإعداد المستطاع من القوَّة يختلف الأمر الرَّبَنْيُ فيه باختلاف الأزمان، ودرجات الاسنطاعة، ونوع القوَّة

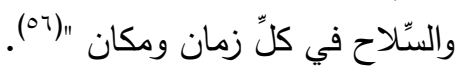

هذا فيما يتعلَّق بالنَّصر في المعارك، وانتصار الرُّل والأنبياء وانتصار دعواتهم. وهناك النَّصر في

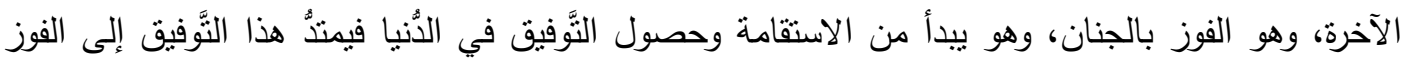

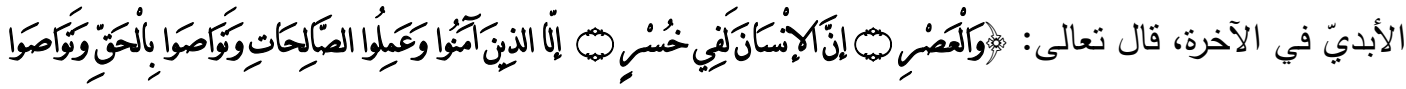

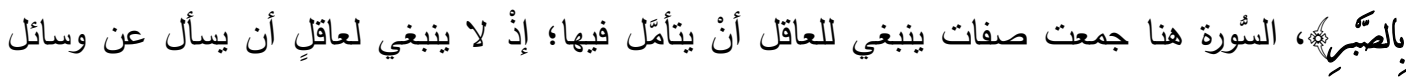


النَّصر وأسبابه قبل أن يرفع نفسه ومن معه دخائل الخسارة وموجبات النَّصَ، والسُورة هنا جزمت بقسم عظيم

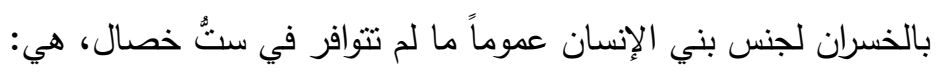

$$
\text { r / / الإيمان. }
$$

r / أن يكون في جماعة، وهذا واضح من مجيء التَّبير بـ (الإنسان) مفرداً، ثنَّ مجيء الاستثناء بصيغة الجمع (إلّا الذين). ـ / وجود مبدأ النَّواصي ومثوله.

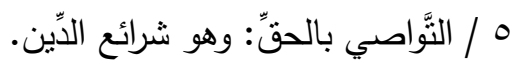
ا 1 / النَّاصي بالصَّبر

إنَّ هذه الخصال الستّ حين تتوافر في جماعة من الجماعات أبِّاً كانت فهي كفيلة بأن تجعلها في ضمان

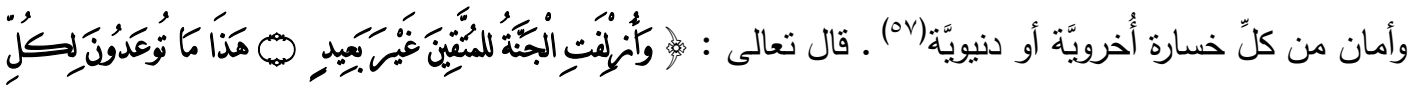

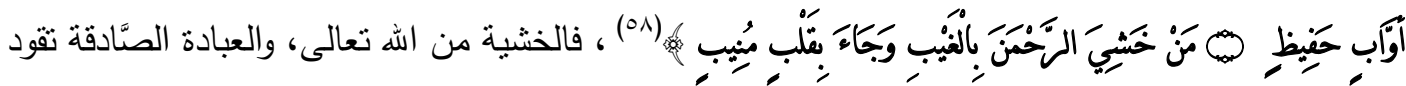

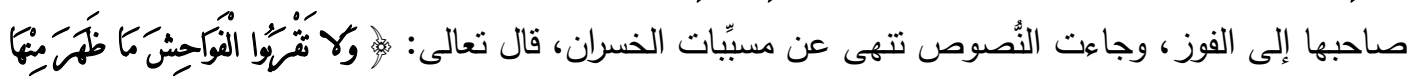

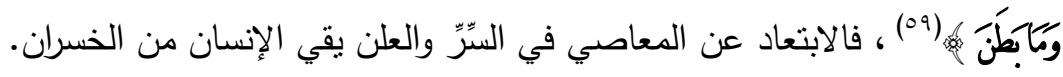

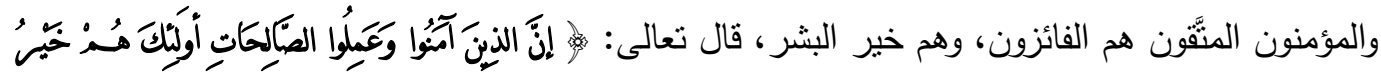

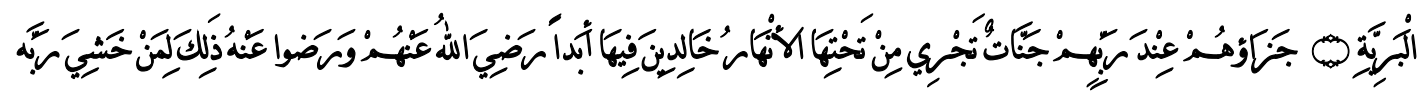

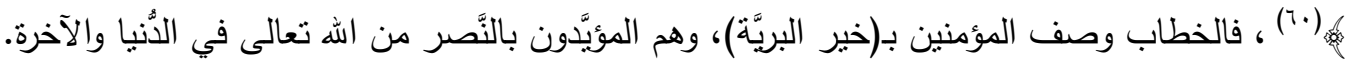




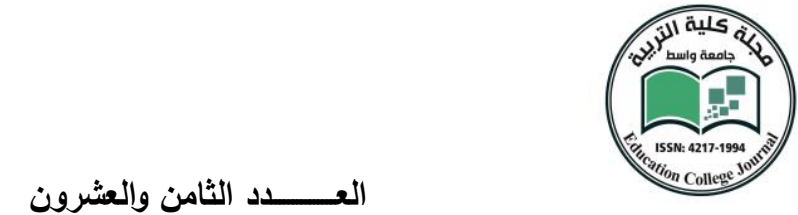

مجلــــة كليــــة التربيــــة

المعيار الأوَّل : القصدية والمقبولية

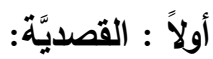

هي أحد المعايير النَّصِّبَة التي حدَّدها دي بوجراند و دريسلر، والقصد يتضَّمن موقف منتج النَّصِّ

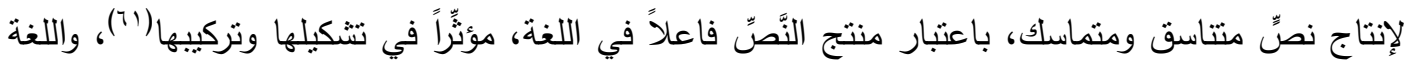

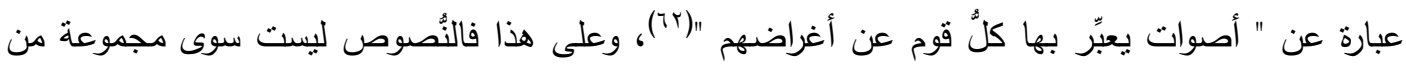

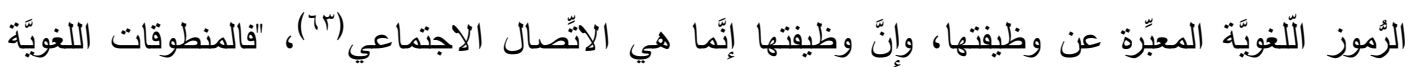

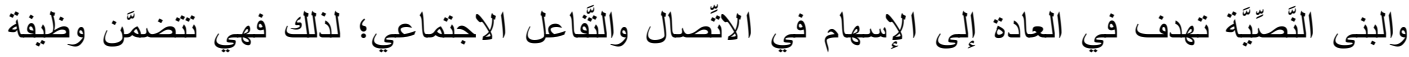
دينامية، ولمحاولة فهم كيف يعمل الخطاب يجب أن نأخذ في الاعتبار الجوانب القصديَّة والمقبوليَّة لنتكيل

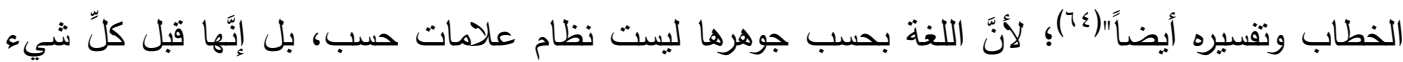

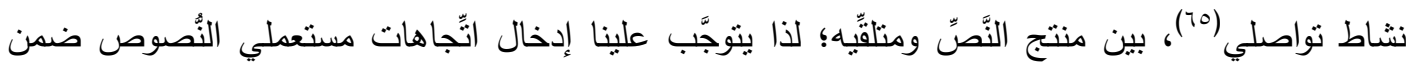

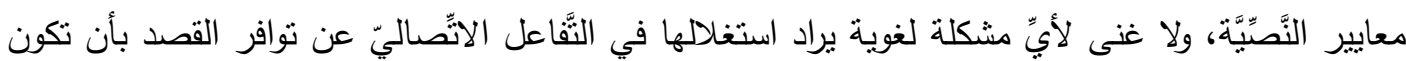

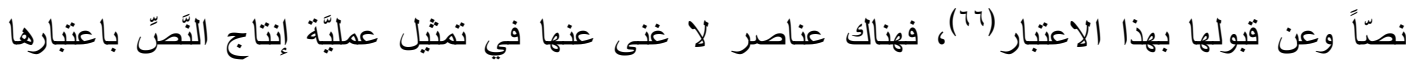

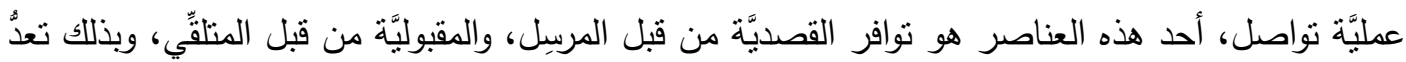

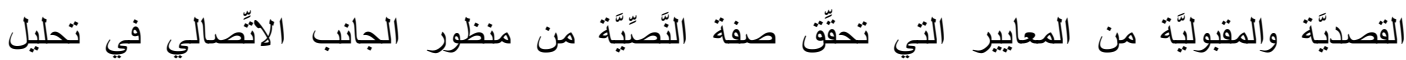

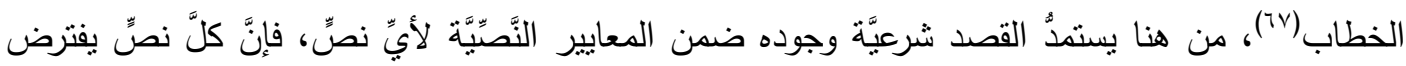

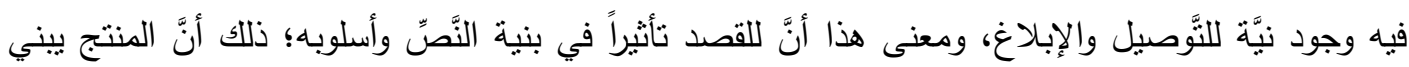

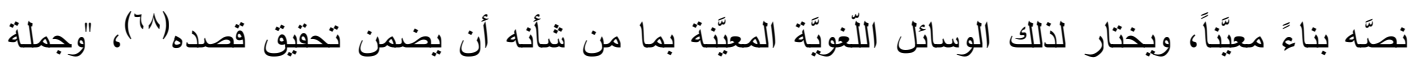

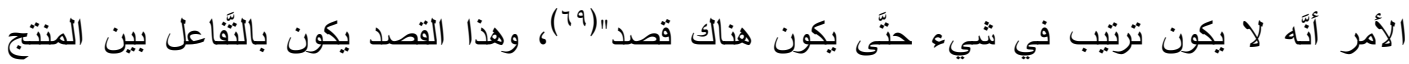

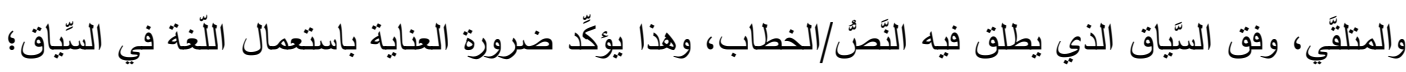

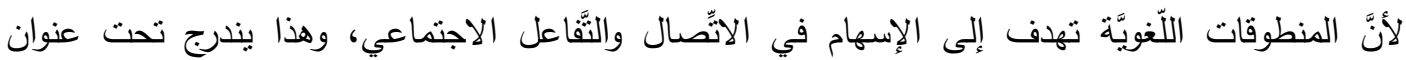

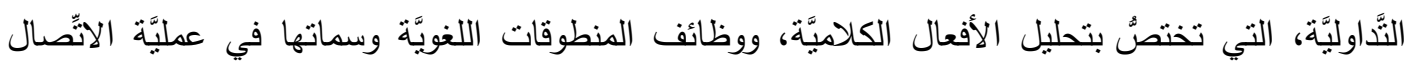

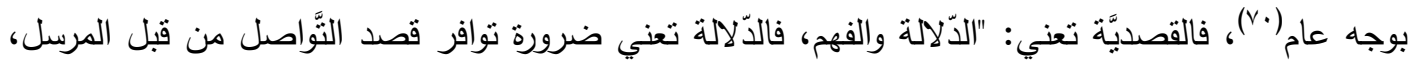

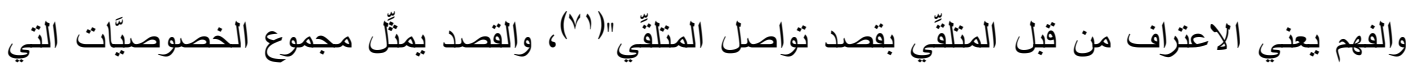

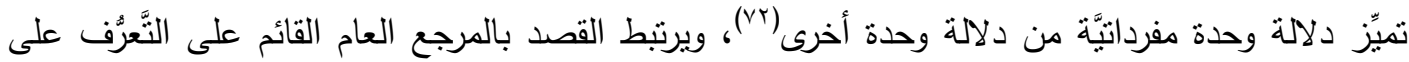

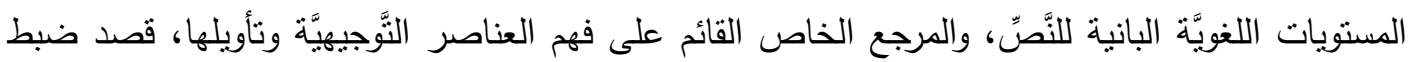


الوظيفة الاتُّاليَّة التي يهدف إليها النَّصُ، ويتمثَّل المرجع العام في تحديد المعارف المشتركة بين منتج

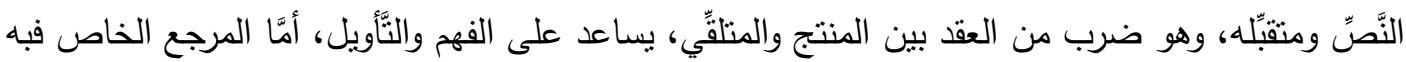

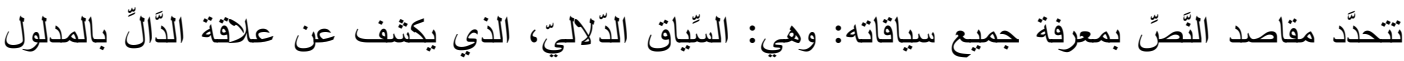

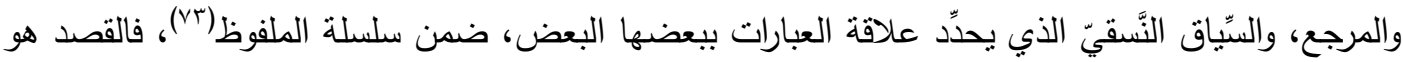

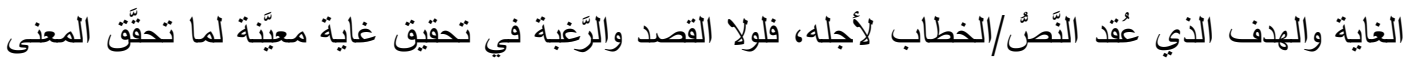

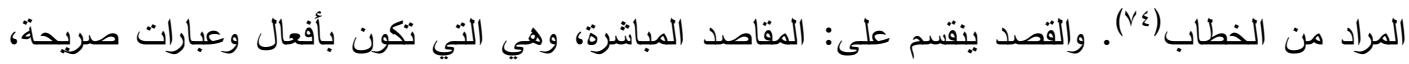

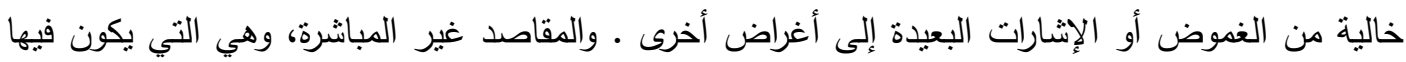

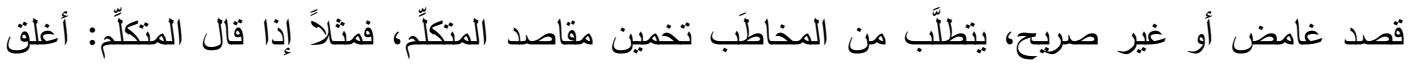

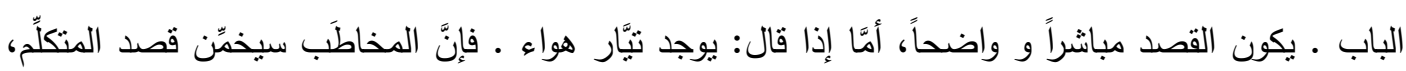

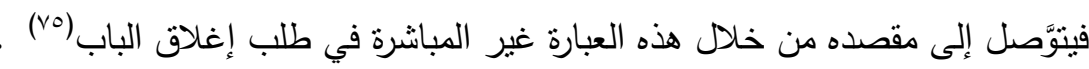

وخطابات القرآن كلُها ترمي إلى سعادة الإنسان من خلال إقراره بوحدانيَّة الله، ونصر دين اله الواحد على الهى

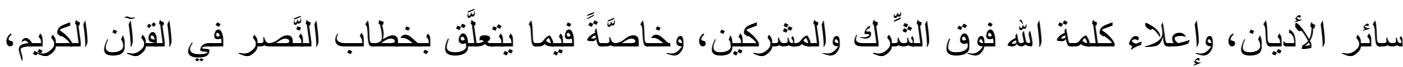
ومقاصد هذا الخطاب جاءت على:

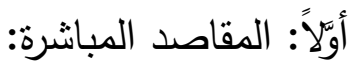

هي المقاصد التي لا تحتاج إلى تأويل واجتهاد في فهم معنى الخطاب، وأكثر ما جاء من هذا النَّع

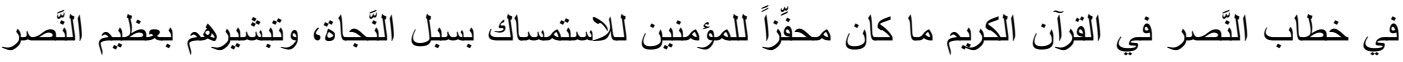

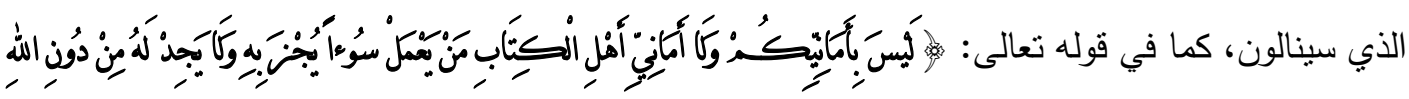

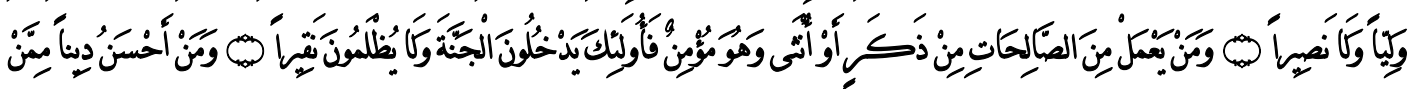

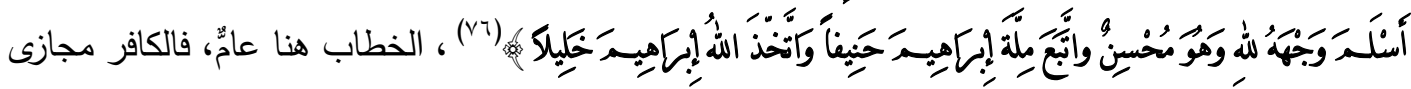

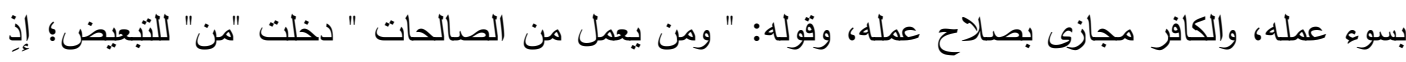

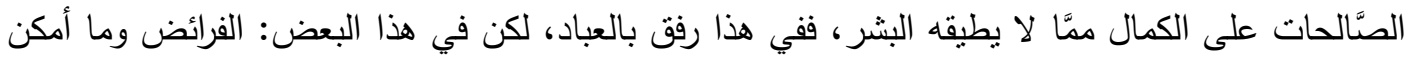

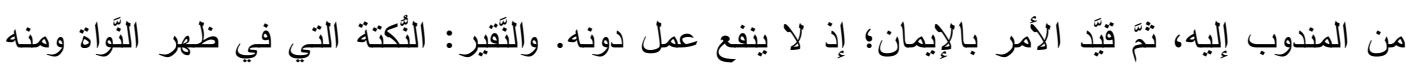




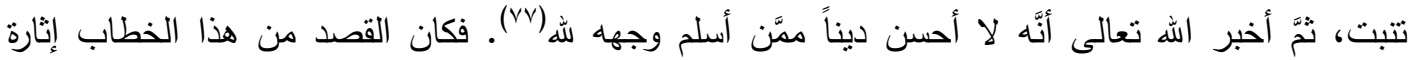

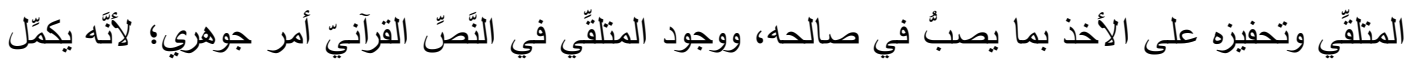

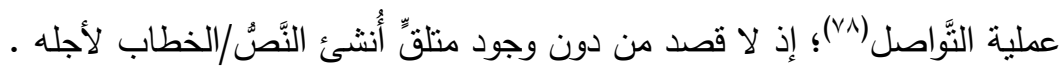

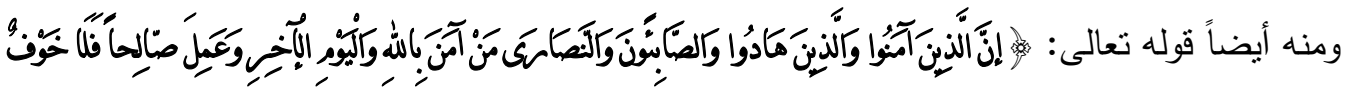

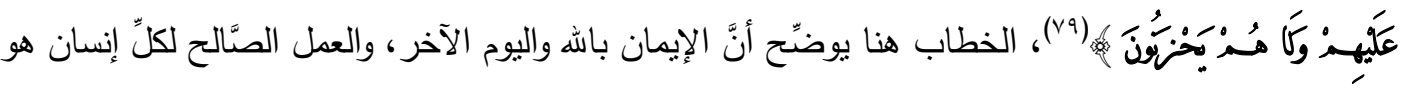

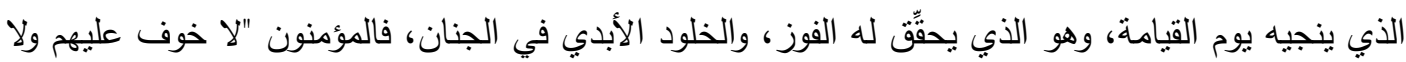
هم يحزنون ".

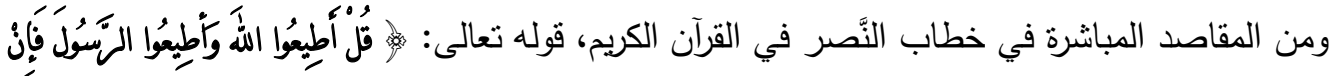

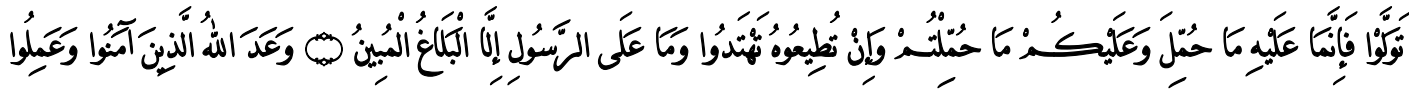

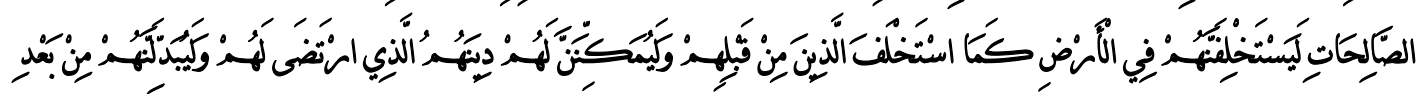

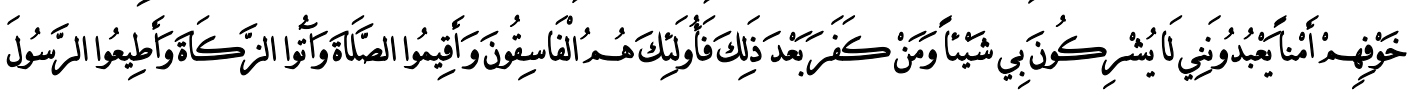

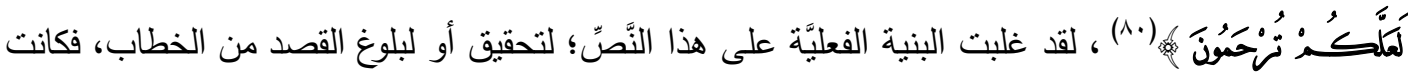

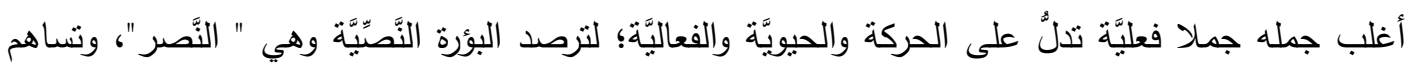

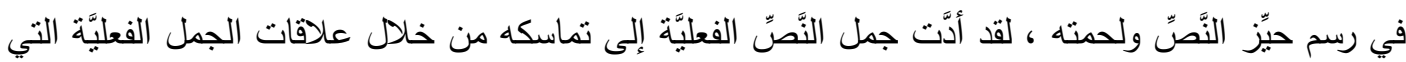

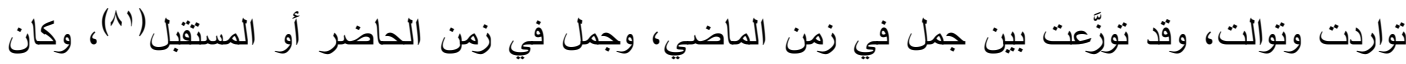

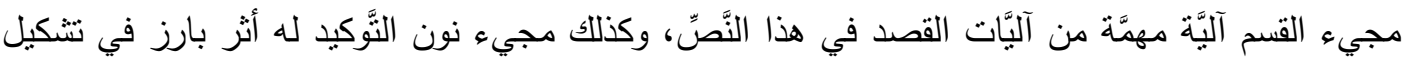
مقصديَّة الخطاب، فقد جاء في الأفعال : " ليستخلفنَّهم ، ليمكنّنَّ ، ليبدِّلَّ ".

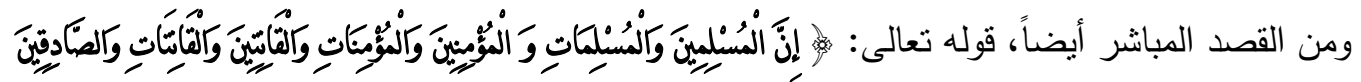

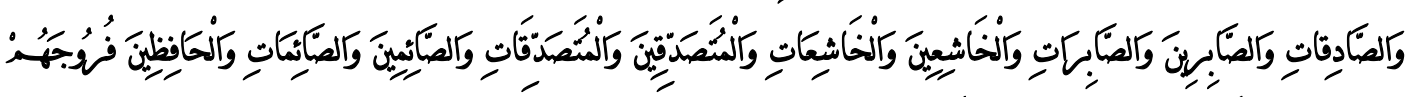

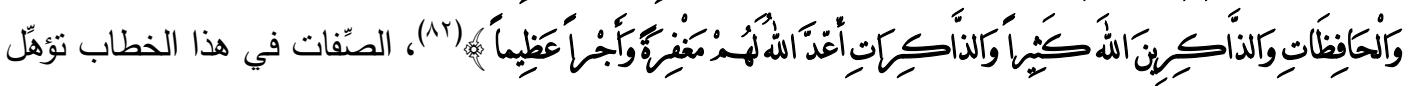
صاحبها للنَّصر الأُخرويّ، ونيل المغفرة والأجر العظيم، وهذا الأمر ينساوى فيه الرّاّال والنّّساء؛ لذا جاء 


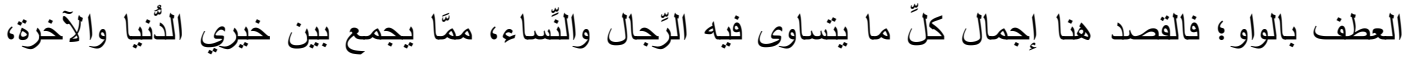

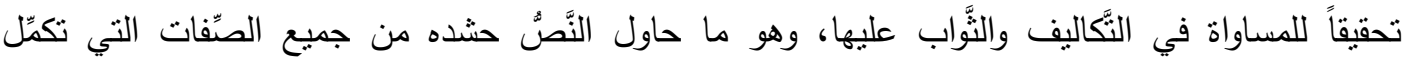
الإنسان في دينه وخُلقه، وتعينه على الوصول إلى مرضاة الله، من حسن الإسلام وعمق الإيمان ، والصيّدق،

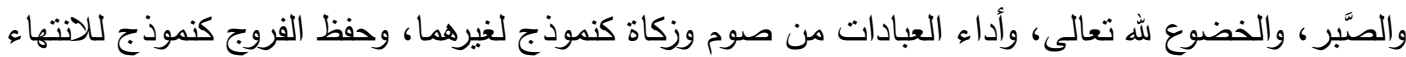

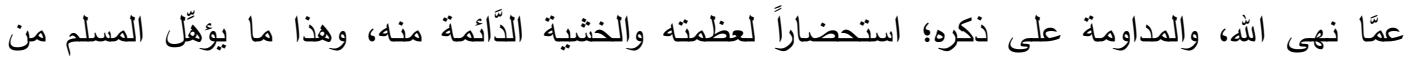

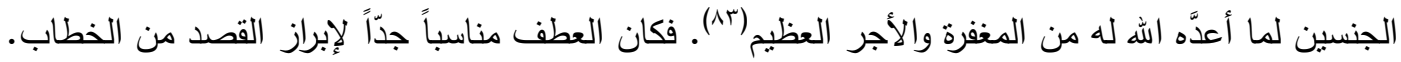

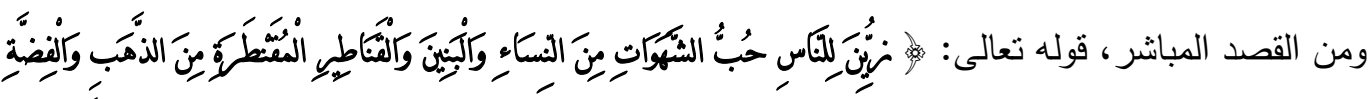

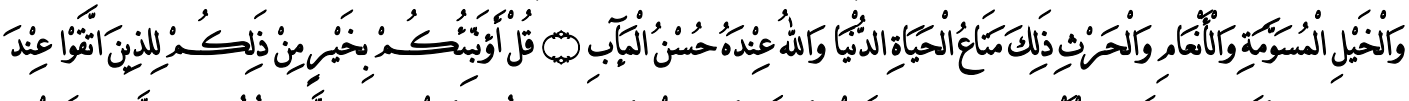

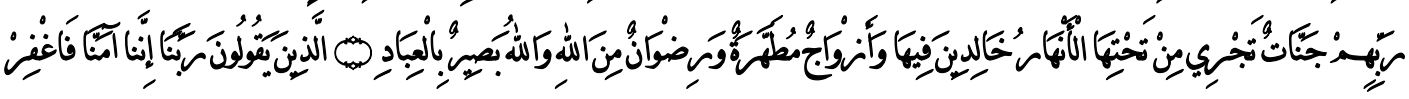

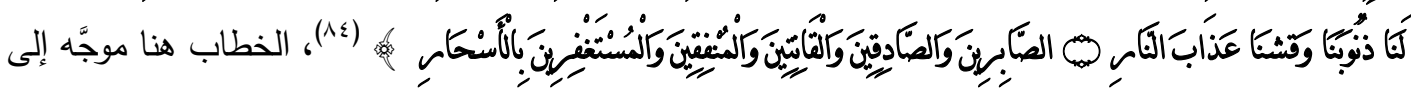

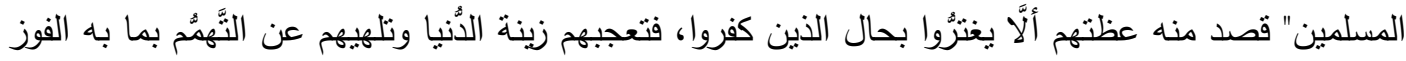

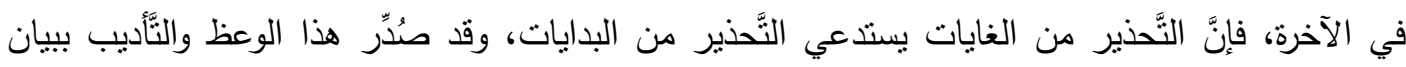

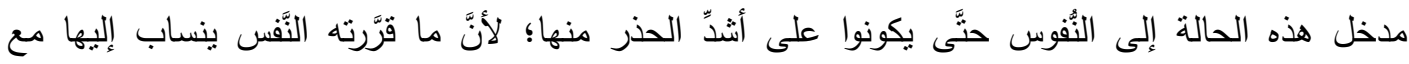

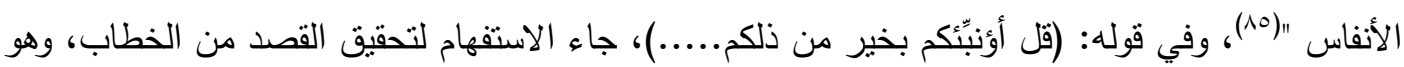

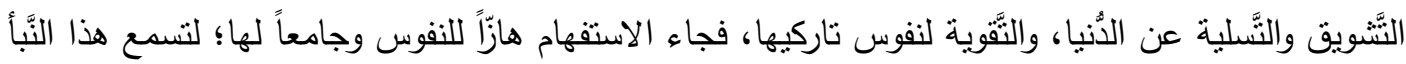

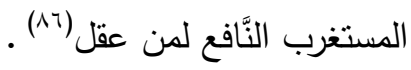

وقد تأتي نصوص متثابهة في المعنى، لكنَّها تختلف في طريقة العرض تبعاً للقصد والغرض منها ، كما

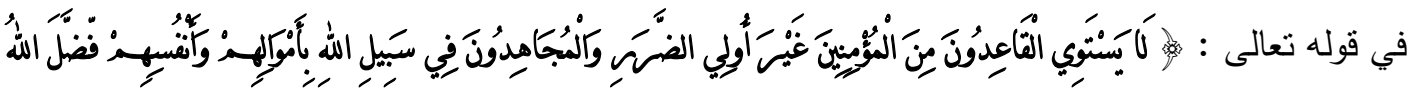

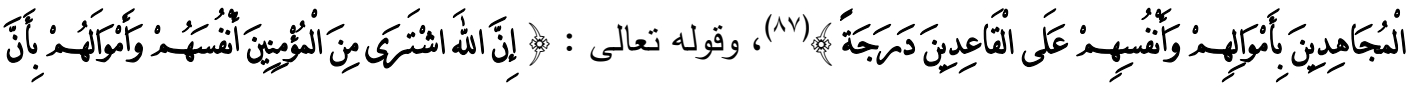

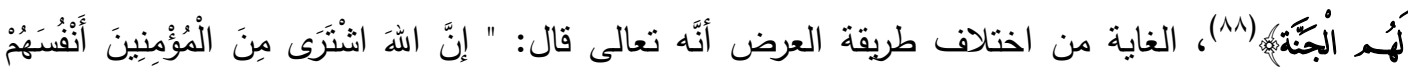

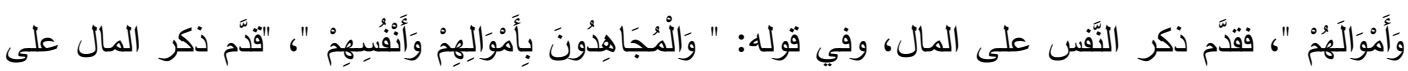

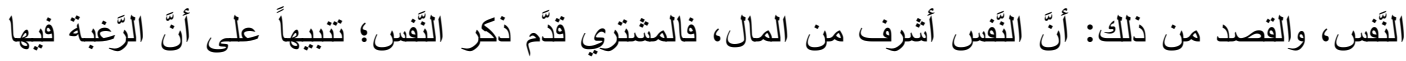




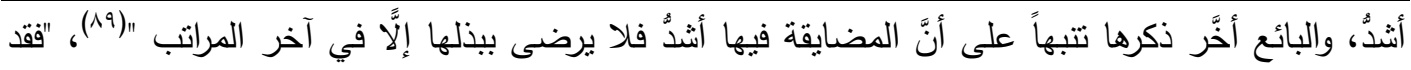

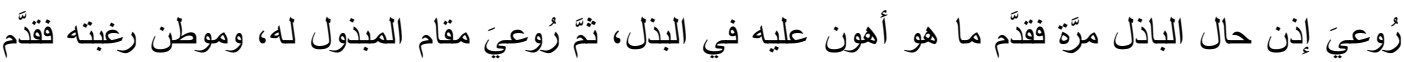

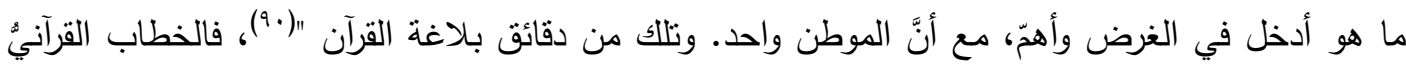

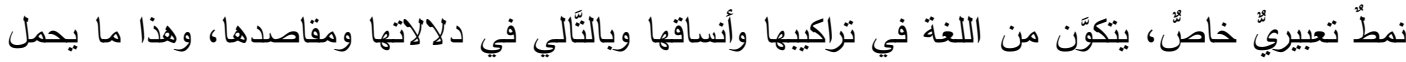

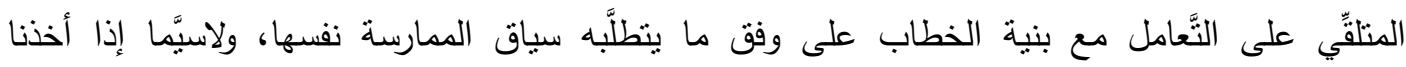

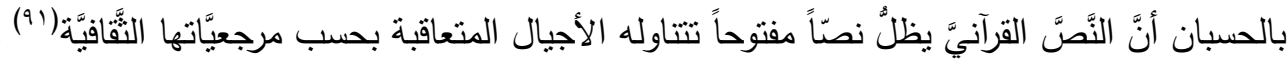

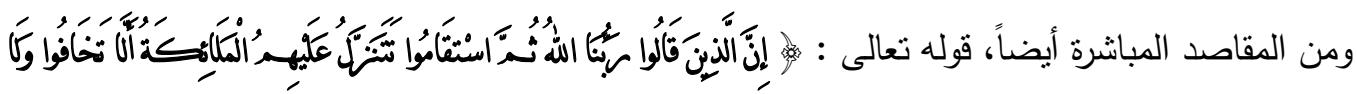

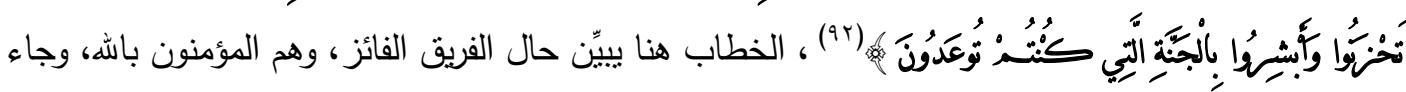

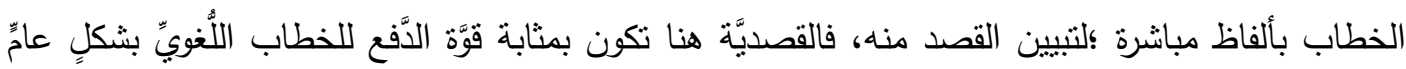

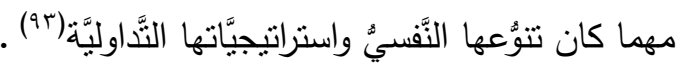

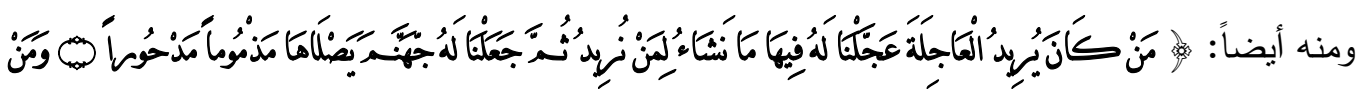

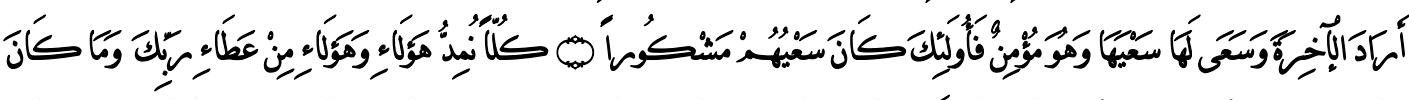

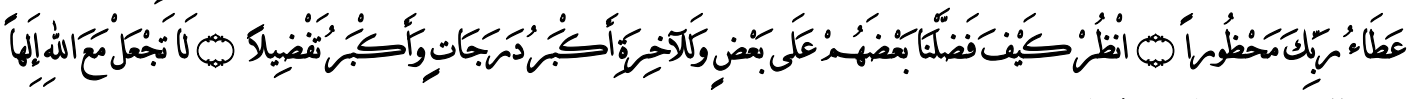

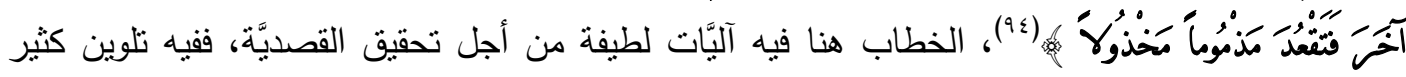
"ورجه التَّلمين ظاهر في الانتقال من صيغة مرتَّة للفعل الماضي (كان بريد) إلى صيغة مجرَّدة منه (أراد)،

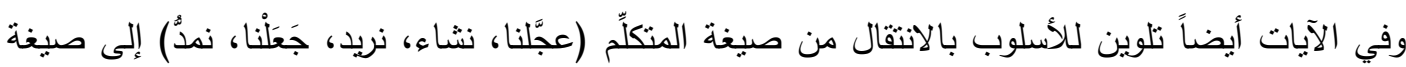

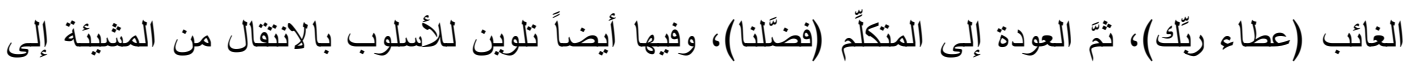

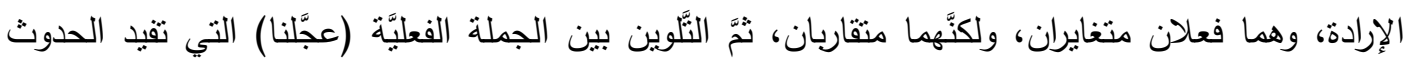

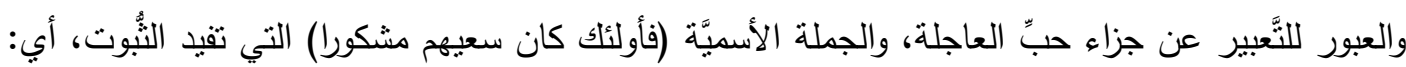

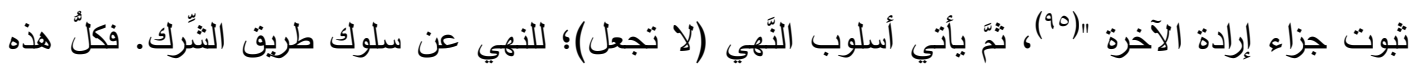

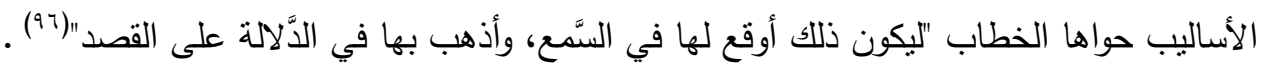


تتجلَّى هذه المقاصد في الأساليب البلاغيَّة التي يضمُّها الخطاب، وهذه الأساليب تظهر البعد التَّاوليّ؛ إذ هناك قصد في نفس منتج النَّصِّ، وهذا القصد يكثفه المتلقِّي بإعمال الفكر، وأحياناً هنالك تلوينات بلاغيَّة نستدعي إثارة العاطفة وذلك وفق القرائن والسِّياقات التي يُنتج فيها النَّصُّ. من ذلك: المجاز

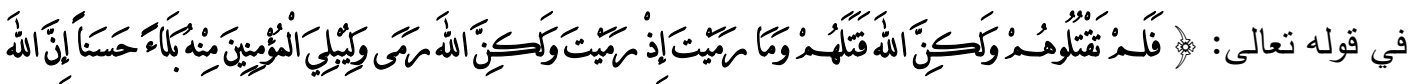

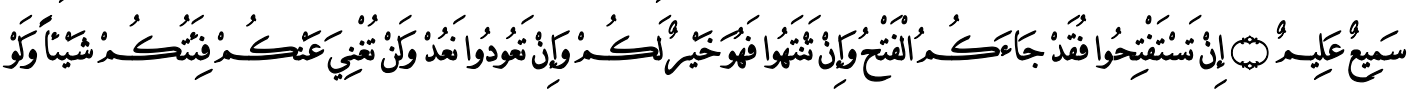

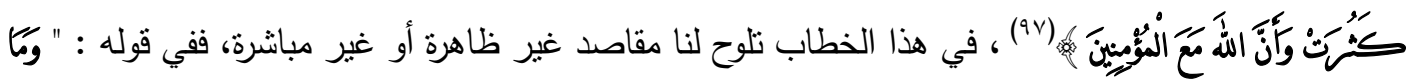

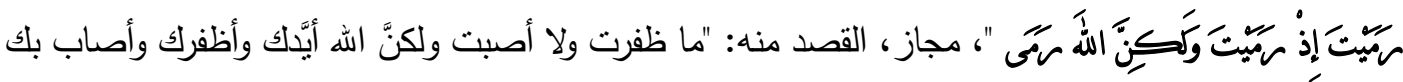

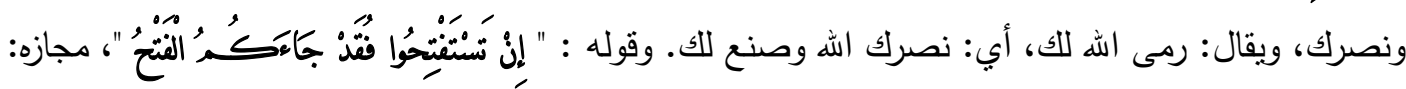

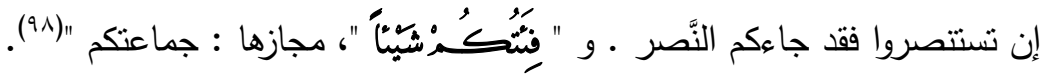

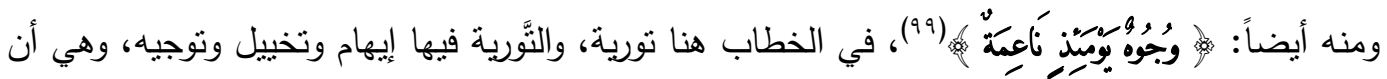
يتكلّم المتكلِّم بلفظ مشترك بين معنيين: قريب وبعيد، ويريد المعنى البعيد، يوهم السَّامع أنَّهَ أراد القريب، ففي

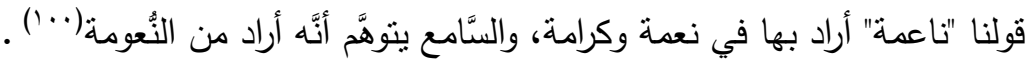

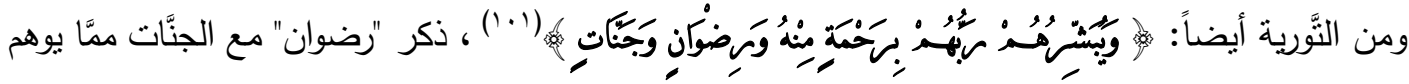
إرادة خازن الجنَّات، فالسَّامع يتوهَّم في بادئ الأمر، والذي يزيل هذا التَّوهُم هو معرفة قواعد التَّخاطب

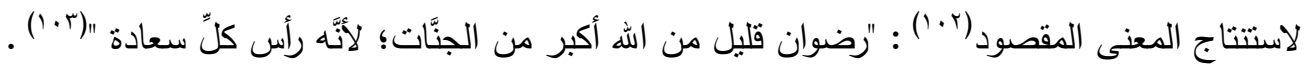

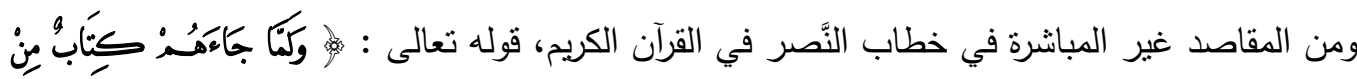

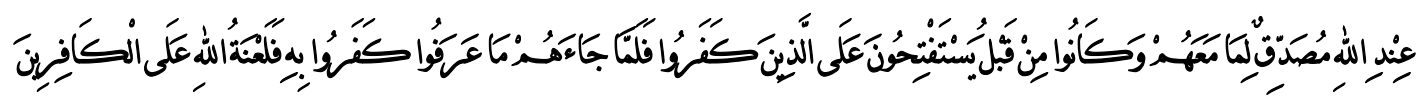
هُ (1) ، "الكتاب" هو القرآن، وإسناد المجيء إليه مجاز ، وقوله "يستقتحون": أي: يستحكمون أو يستعلمون أو 
العــــــد الثامن والعشرون

مجــــة كليــة التربيــة

يستتصرون، يقولون إذا دهمهم العدوُ: اللهمَّ انصرنا عليهم بالنبيّ المبعوث في آخر الزَّمان، الذي نجد نعته

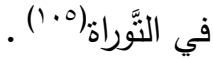

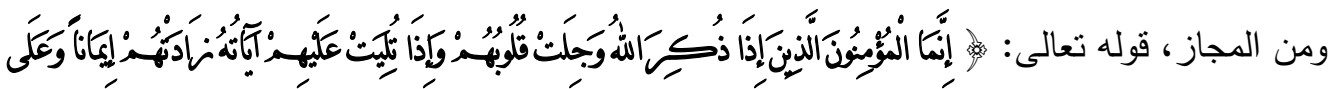

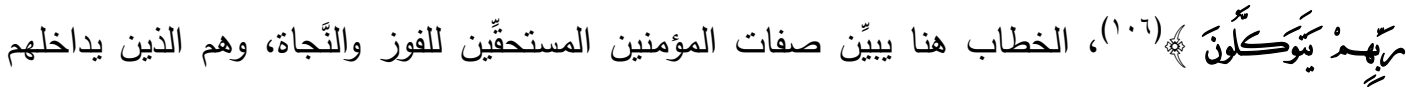

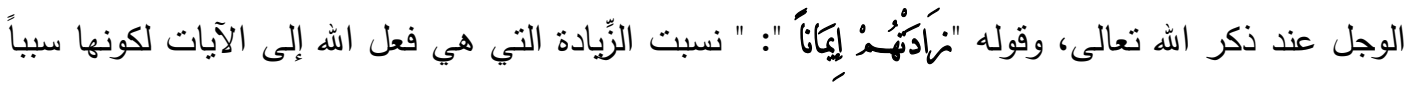

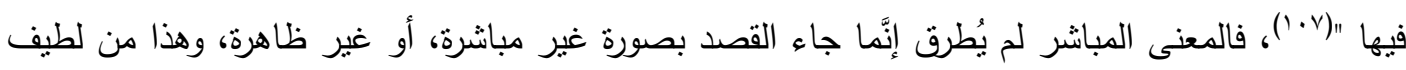

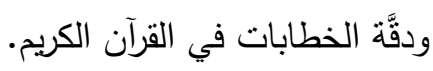

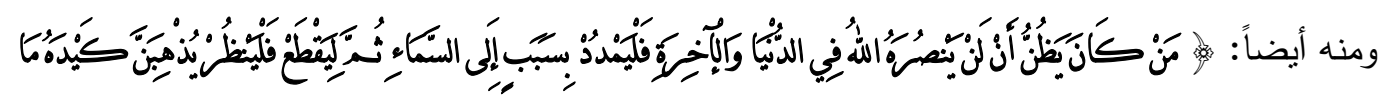

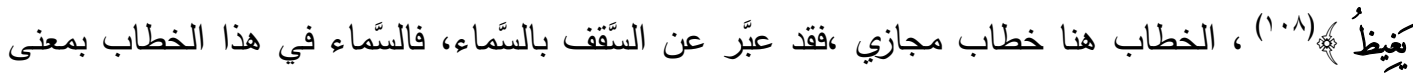

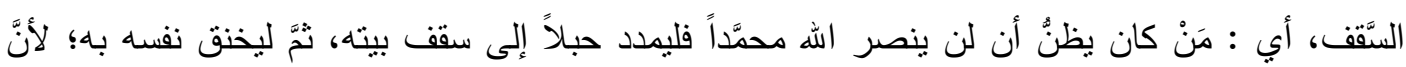

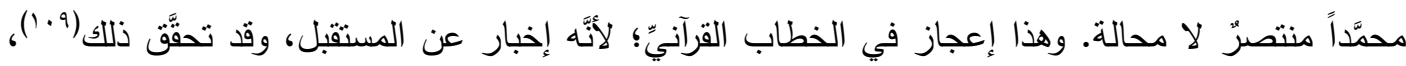

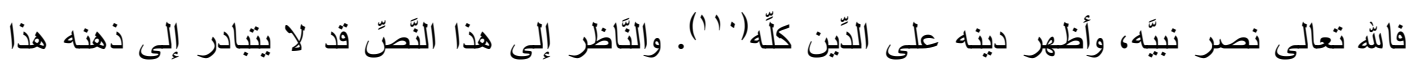

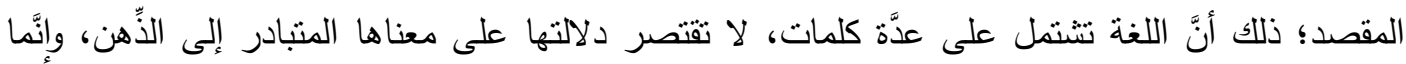

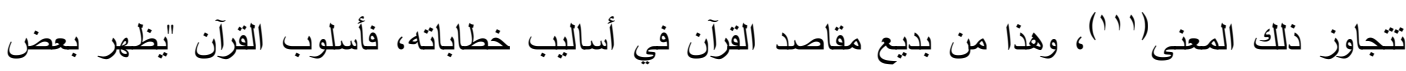

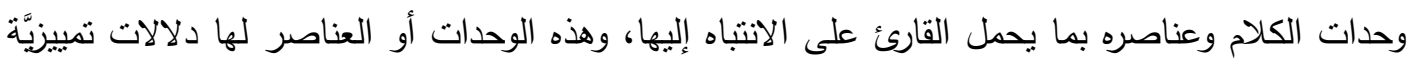

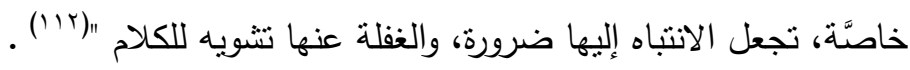

\section{ثنانياً: المقبوليَّة:}

الخطاب أو عمليَّة الثَّاصل نقوم على ركائز ثنلاث، هي: المنتج، والمتلقِّي، محتوى الخطاب، فدور

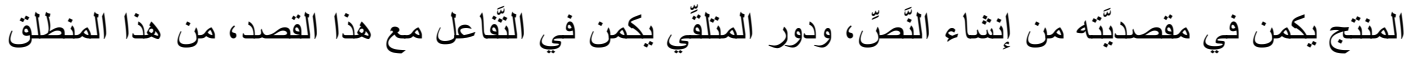

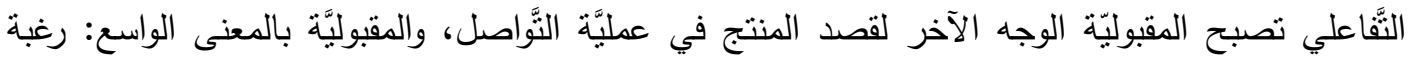

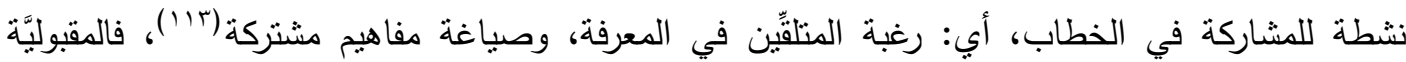


تتضمَّن موقف مستقبل النَّصِّ إزاء كون صورةٍ ما من صور اللُّة ينبغي لها أن تكون مقبولة من حيث هي

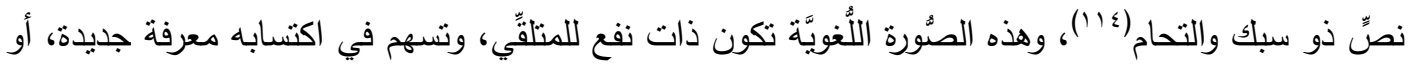

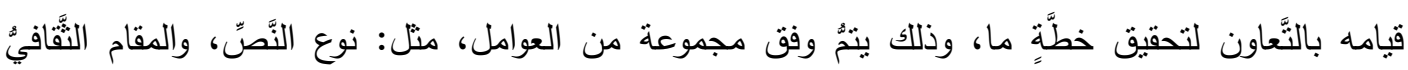
والاجتماعيٌ، ومرغوبيَّة الأهداف(10)، وأهداف القرآن بالدَّرجة الأولى جاءت لترسيخ الاعتقاد باله تعالى، وضرورة الثَّكُّل عليه، وهذا ما نلحظه في خطاب النَّصر في القرآن الكريم، فالقرآن منتج ثقافيُّ، وهو النَّصُّ

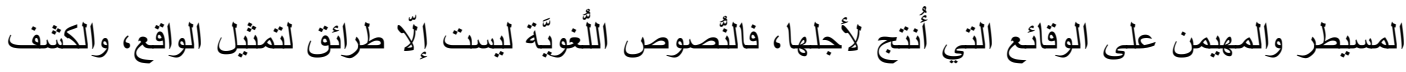
عنه بفعاليَّة خاصيّة(17'). وإنَّ الخطاب يتقولب بحسب المتلقِّ، أي يتشكَّل لإيصال مغزى الخطاب له، أو ليصفه بحسب أحواله، أو يقرأ مواصفات هذا المتلقِي، وغرضه،، وتقكيره، وسلوكه. والمقبوليَّة نتوخَّاها من

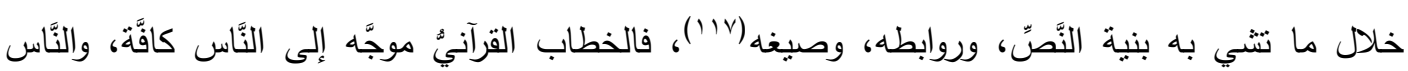
متفاوتون في ثقافاتهم، وأفكارهم، ومعتقداتهم، وبالتَّالي فهناك المنقبّل للنَّصِّ القرآنيّ، وهناك الرَّافض، وممَّا جاء

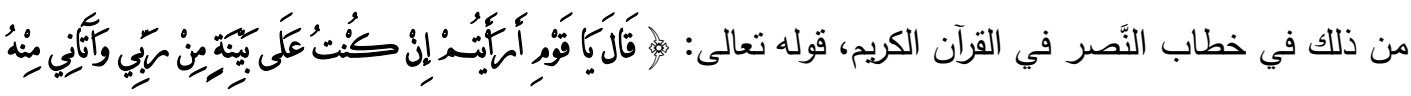

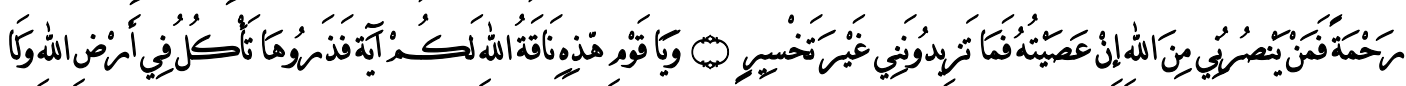

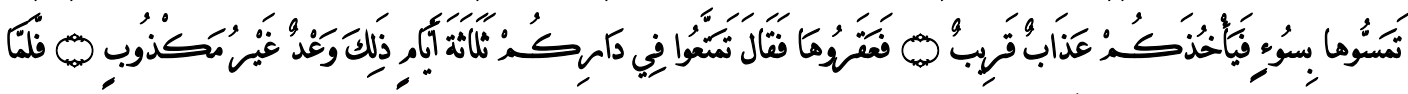

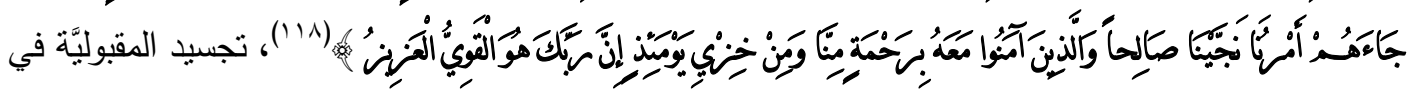
هذا الخطاب يرتكز على نظام فكريٍّ، ونسق ثقافيٍ يتمنَّل في شبكة من الأفكار والقيم والمعارف التي يحتويها

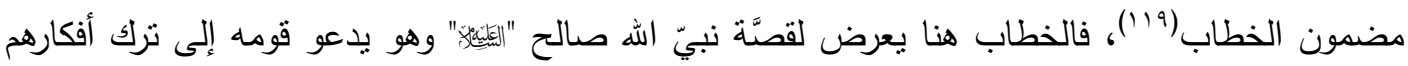

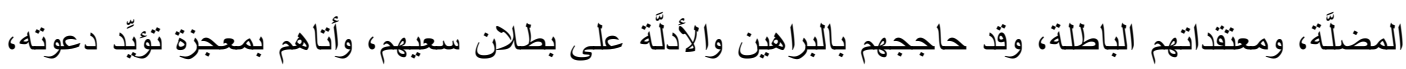
وكان خطابه لهم بأسلوب يشدُّهم إليه، فكان يناديهم "يا قوم "، ويخاطبهم بوصف القوميَّة له، فما كان ردُّهم

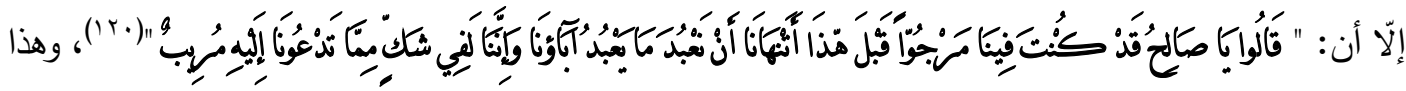
ردٌّ قاطِعٌ منهم بعدم قبول هذه الدَّعوة، وهذا الخطاب على الرَّغم من الوسائل والأساليب التي اتَّعها نبيّ الله؛ لإغرائهم بعبارات محبوكة توحي إلى التَّسبط، وتروم نفعه؛ لخلق نوع من الانسجام بين المخاطِب 


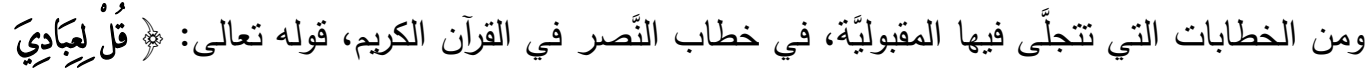

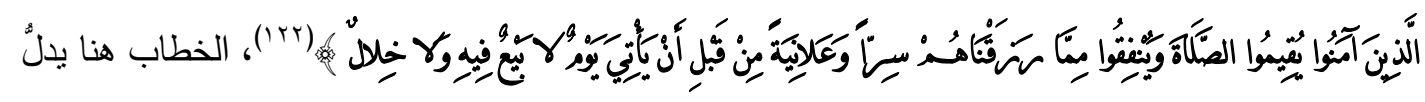

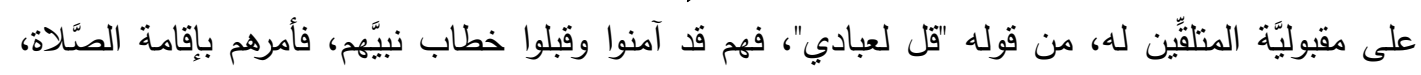

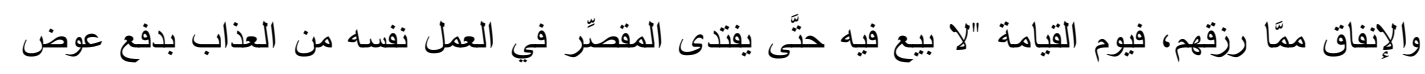

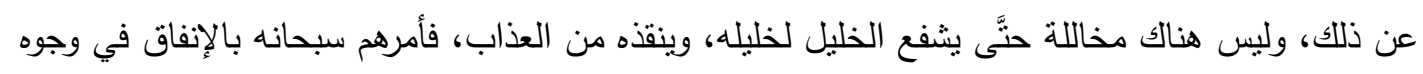

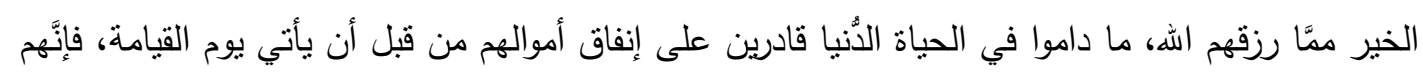

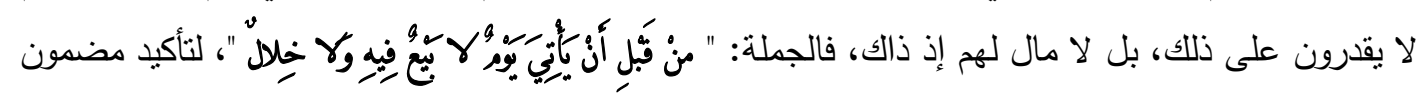

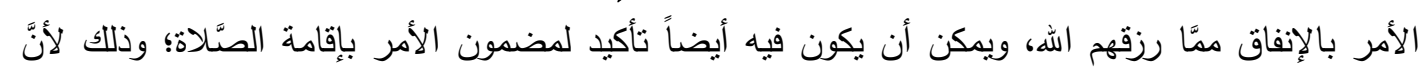

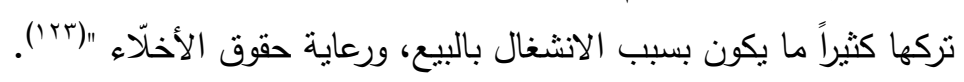

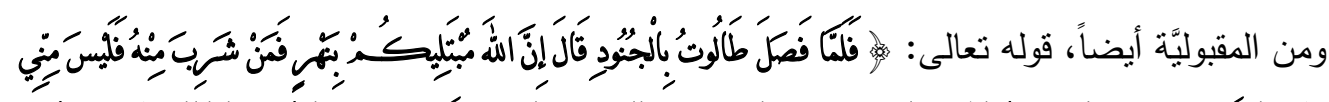

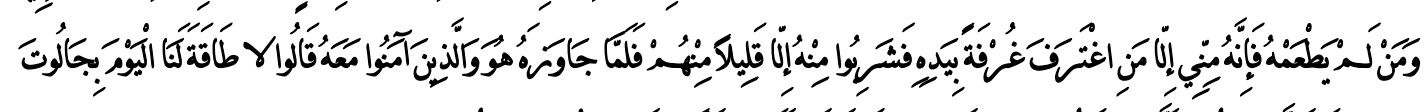

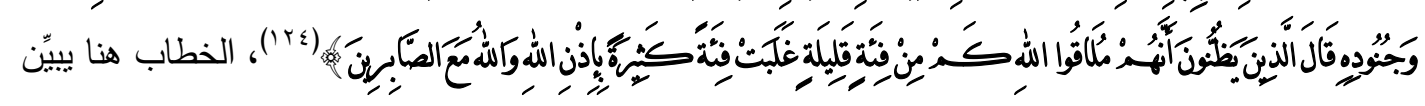

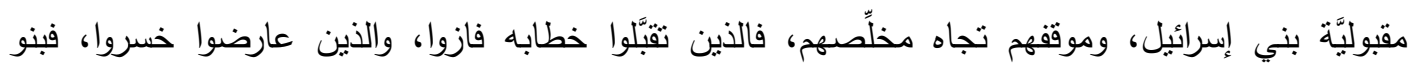

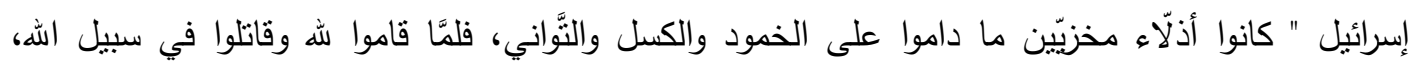

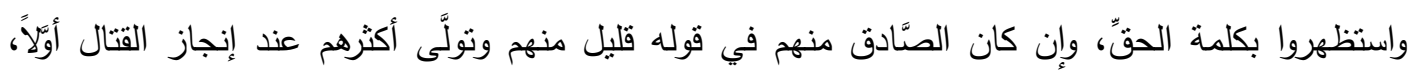

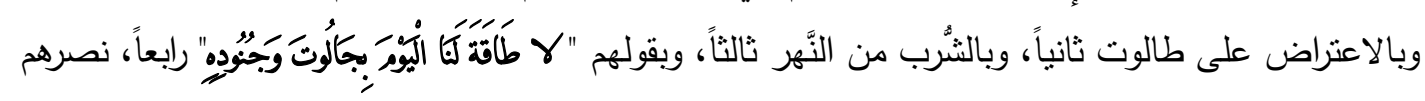

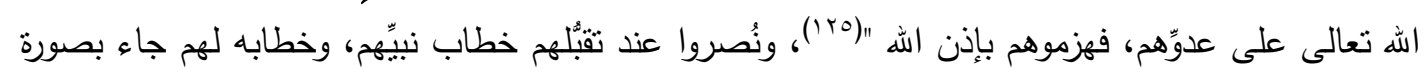

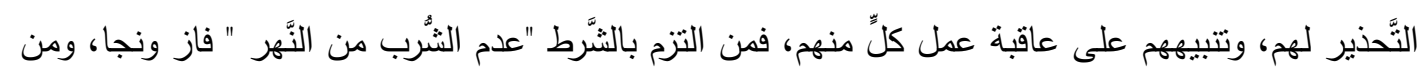

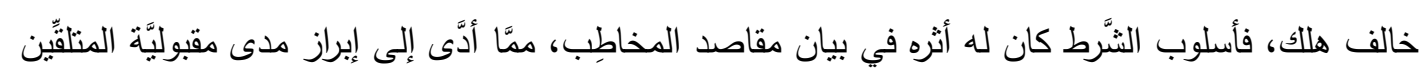


وهي تتضمَّن العوامل التي تجعل النَّصَّ مرتبطاً بموقف سائد يمكن استرجاعه(ب (I) ، والموقفيَّة جزء من السيّاق، الذي ينقسم على قسمين: السيّاق اللغوي، وهو ما يحيط بالمفردة من عبارات تساعد على فهمها،

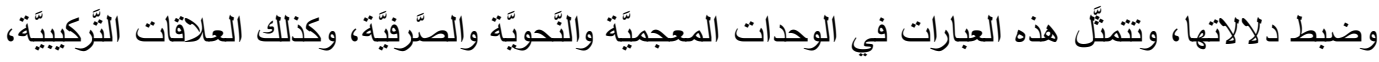

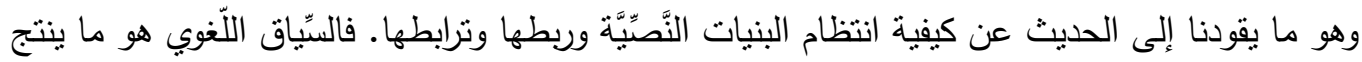

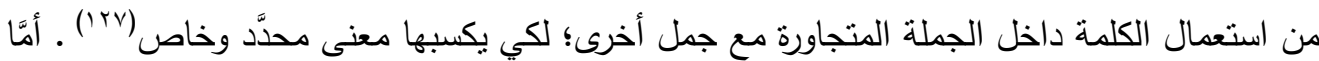

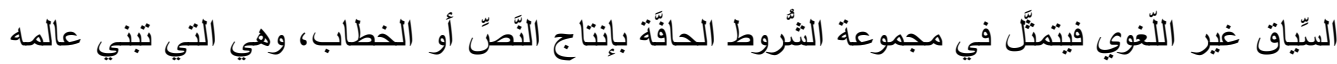

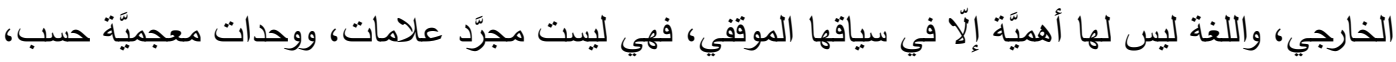

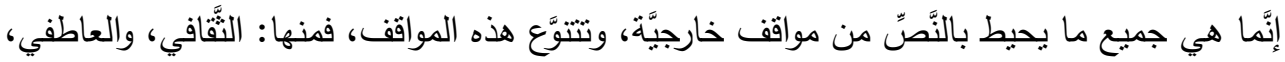
والاجتماعي، فالخطاب شيء ديناميكي؛ لأنَّه نشاط شخصي واجتماعي، يتفاعل مع قوى أخرى في موقف

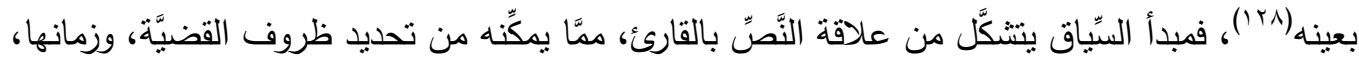

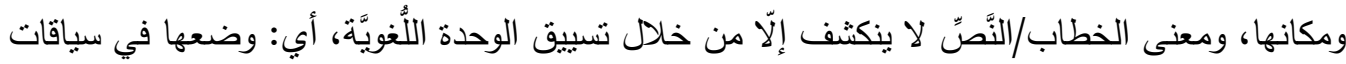

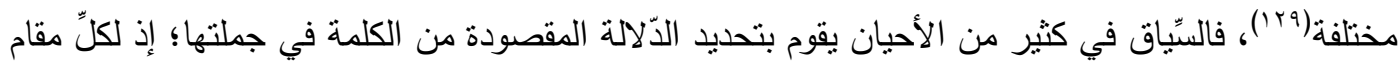

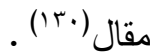

والموقفيَّة في الخطاب القرآنيّ بصورة عامَّة تتعلَّق بأسباب النُزول، فلو أردنا "تفسير أَيَّة حادثة وقعت لا بدَّ

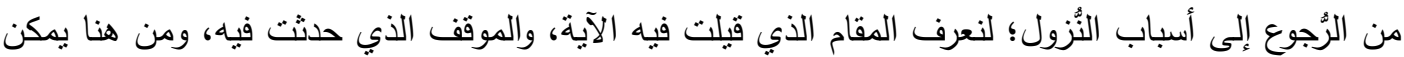

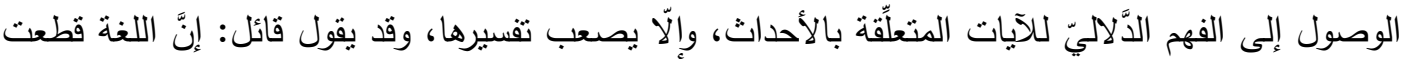

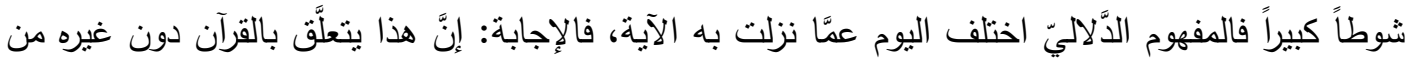

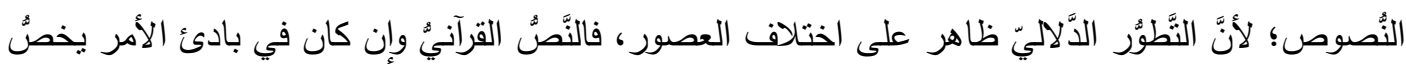

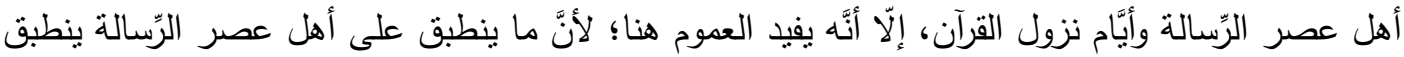

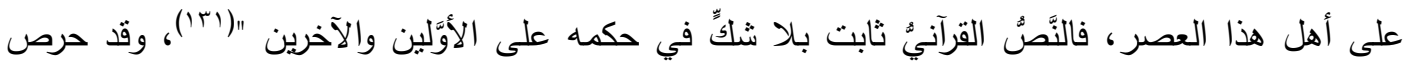

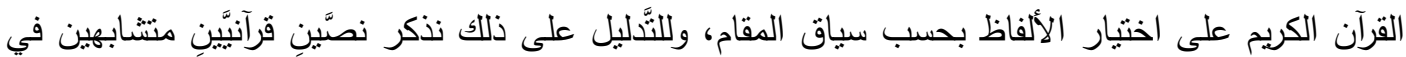

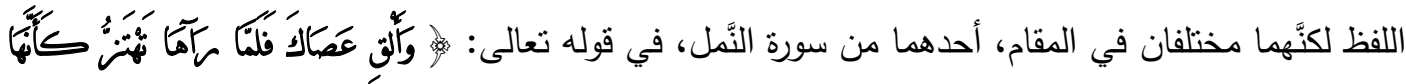




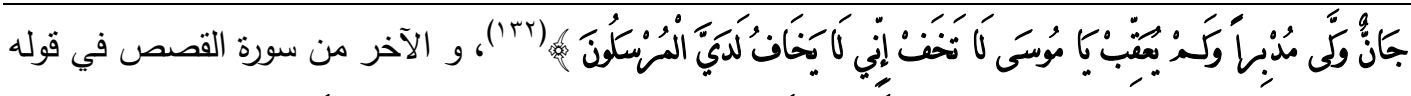

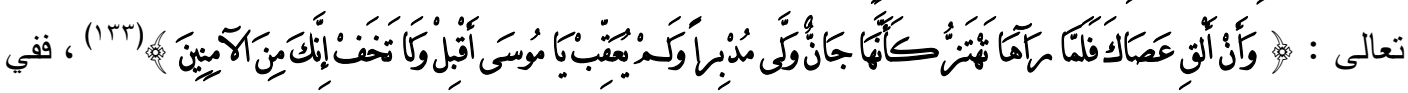

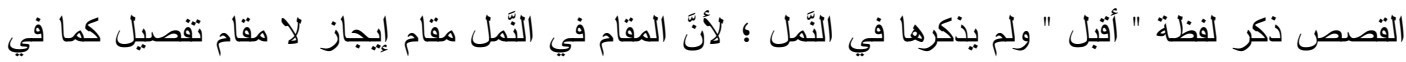

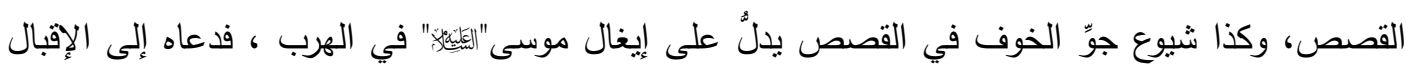

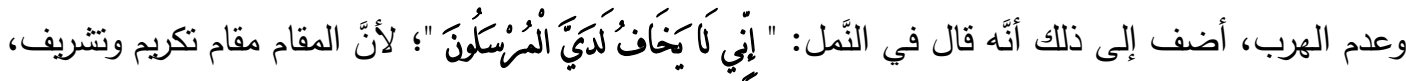

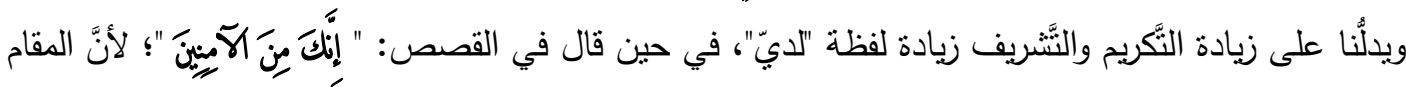

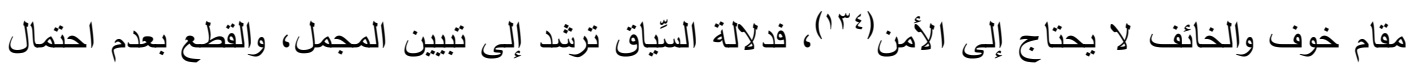

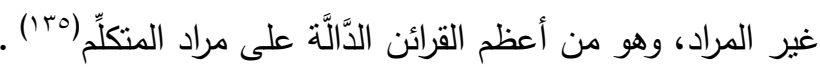

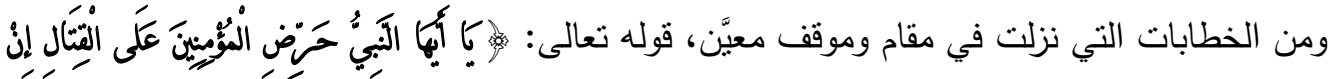

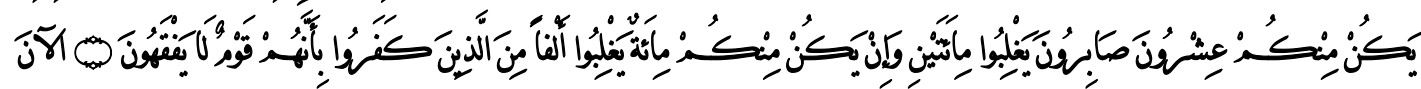

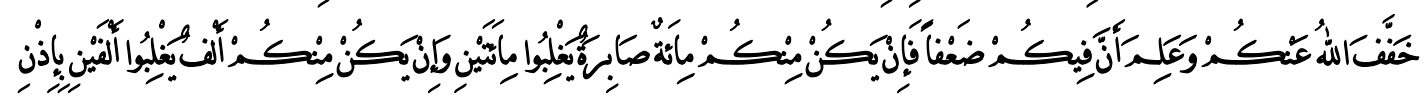

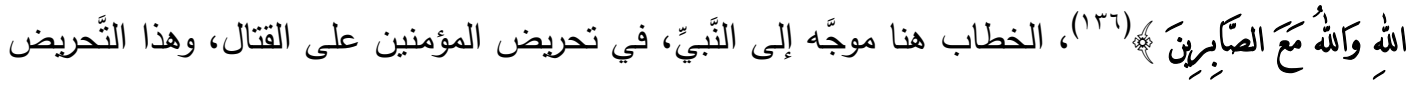

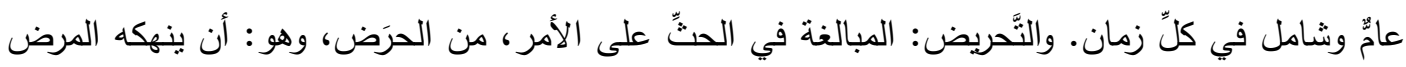

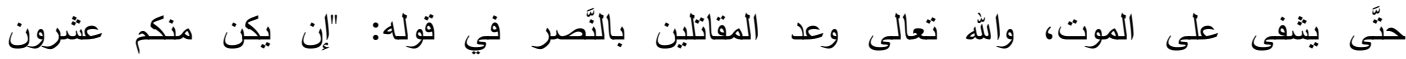

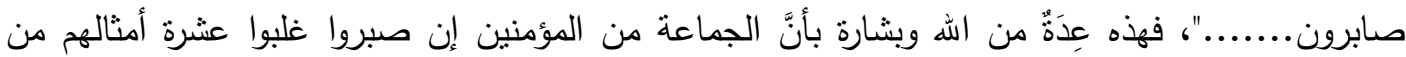

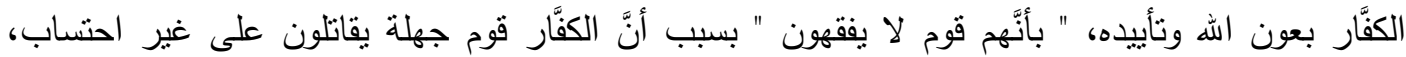

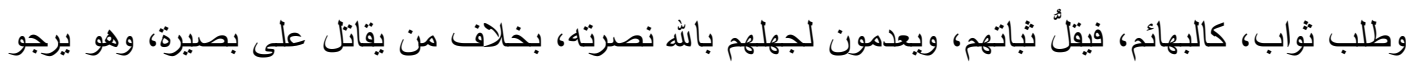

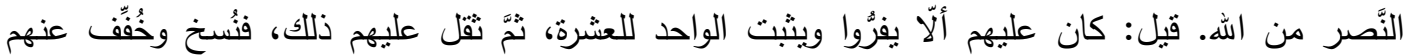

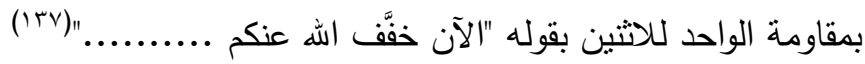

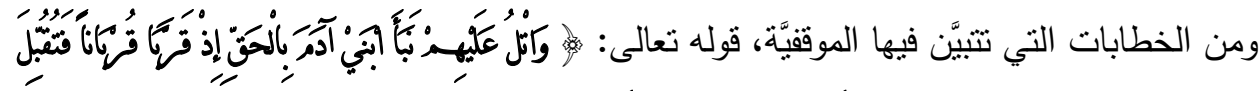

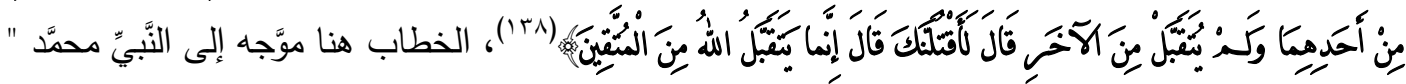

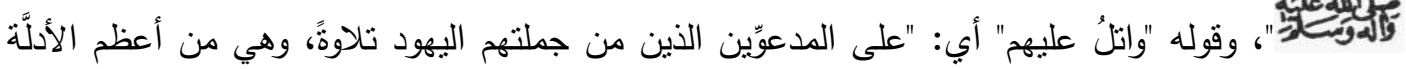




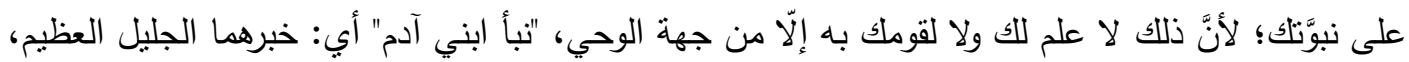

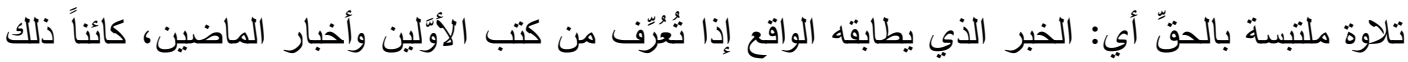

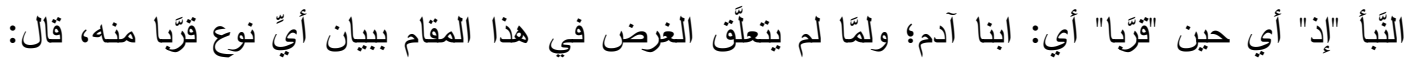

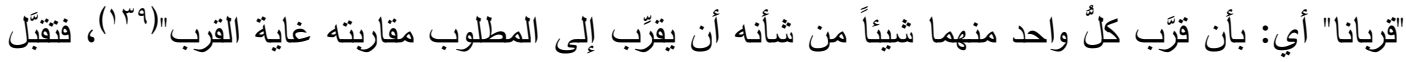

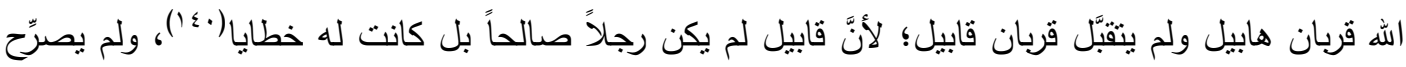

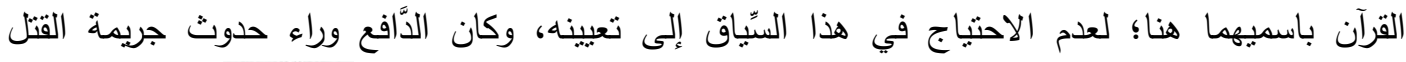

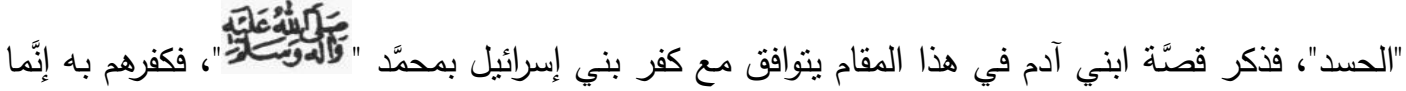

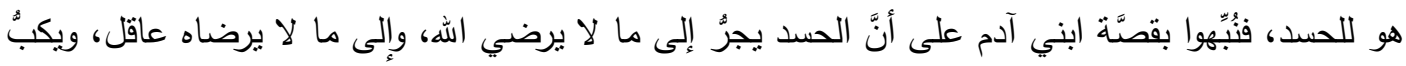

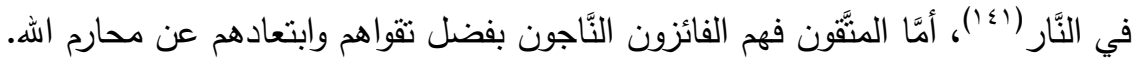

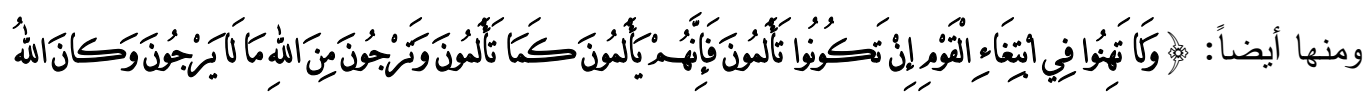

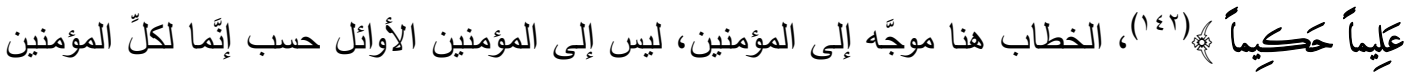

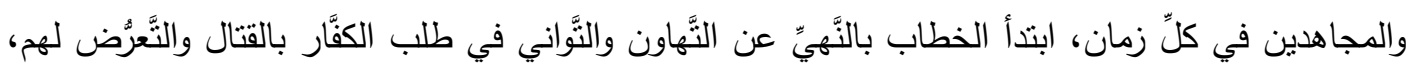

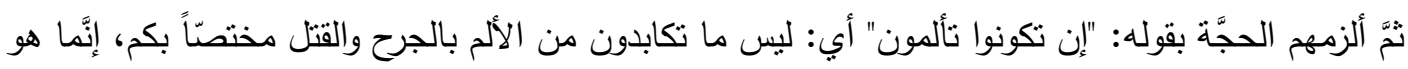

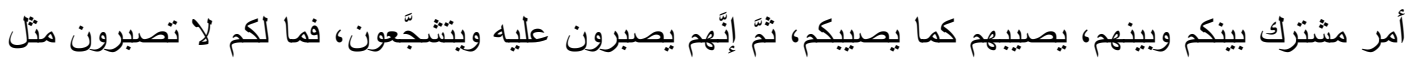

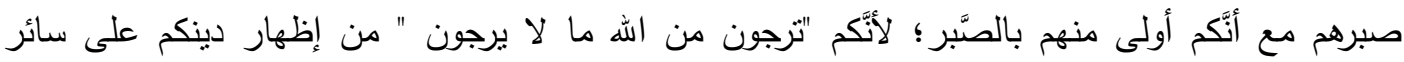

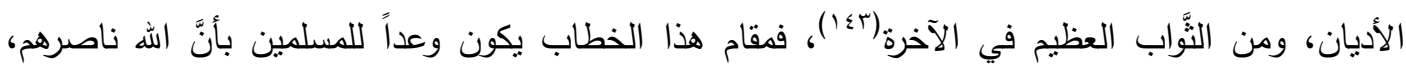

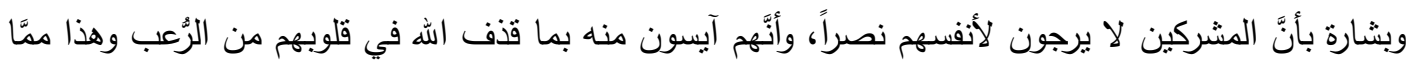

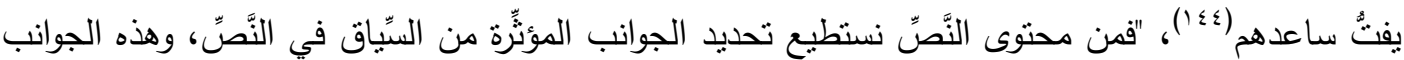

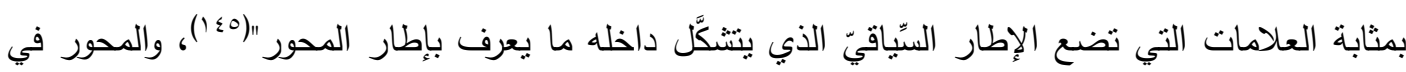

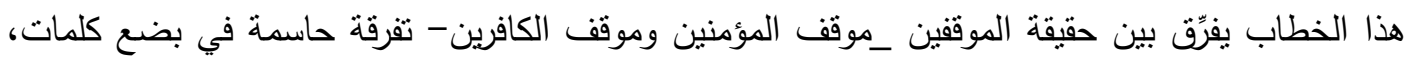

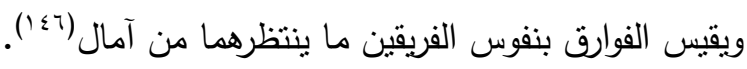

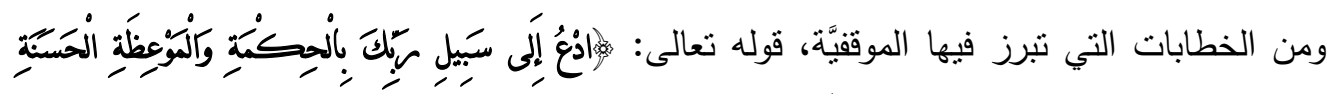

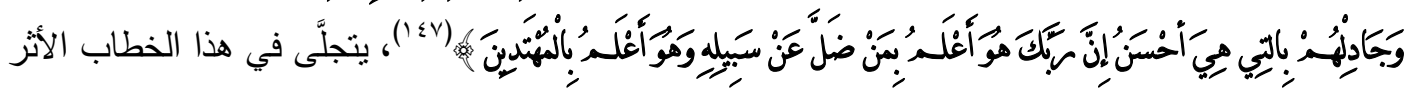


الأسلوبيُّ للقرآن الكريم باحتوائه مجموعة من آليَّات الدَّعوة، تتدرج في استعمال الخطاب وفقاً لمراعاة السيّيّاق،

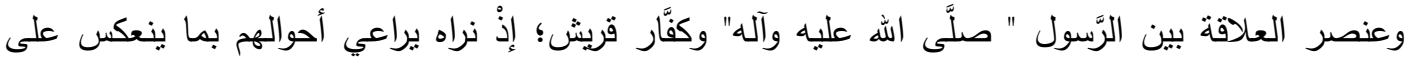

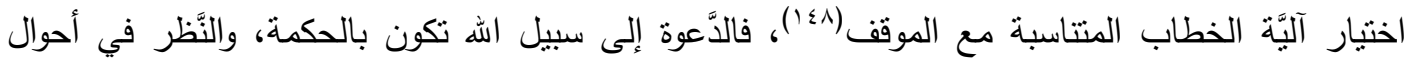

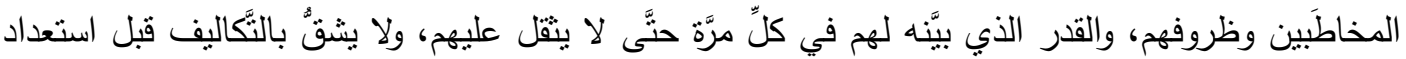

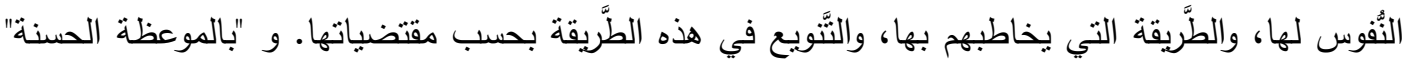

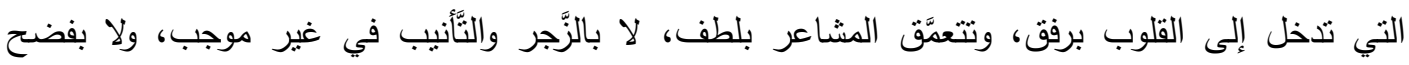

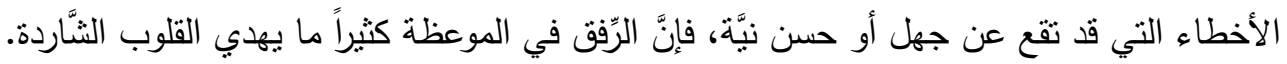

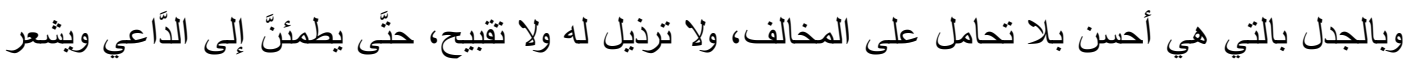
أن ليس هدفه هو الغلبة في الجدل، ولكن الإقتاع في الوصول إلى الحقِّ، فالَّاعي لا يقصد إلّا كثنف الحقيقة

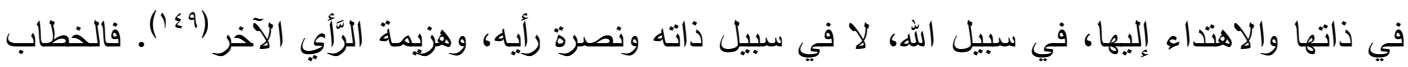

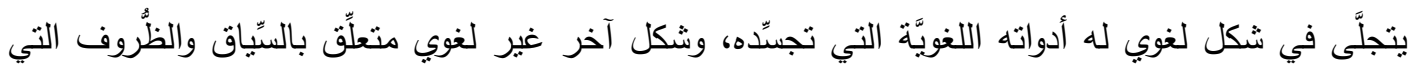

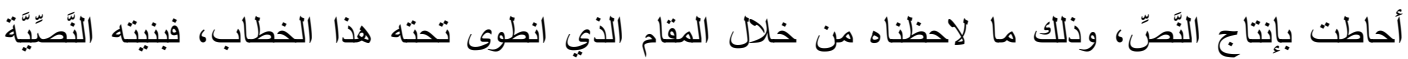
تتوافق وسياقه الخارجي ومقاصده العليا(10.) .

ومن أهمّ المواقف التي تجري على الإنسان هو موقف الفصل بين الفوز والهزيمة، وقد ذُكر هذا الموقف

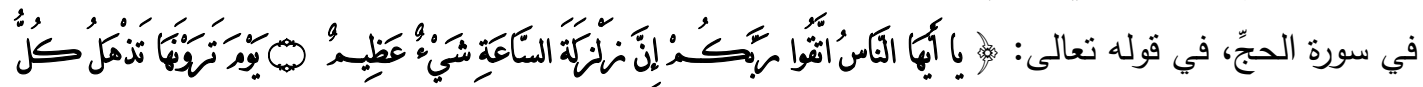

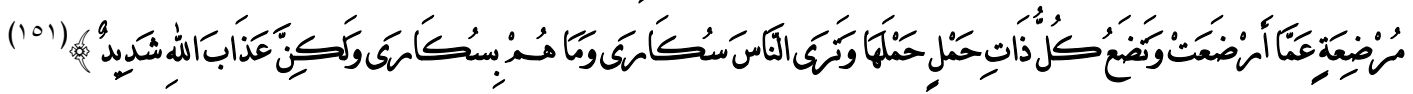

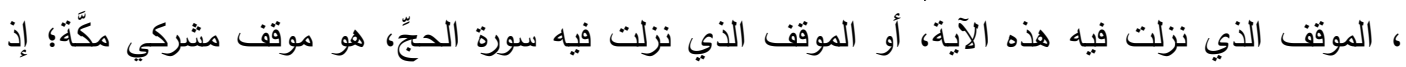

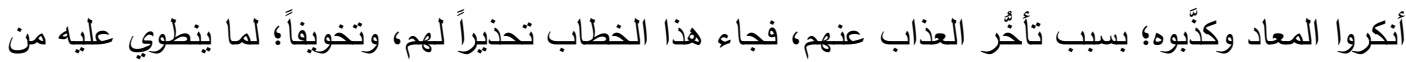

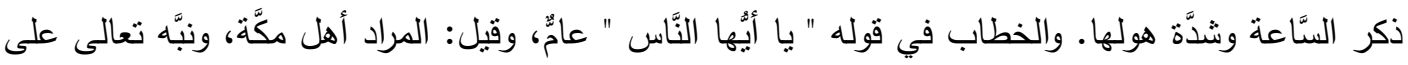

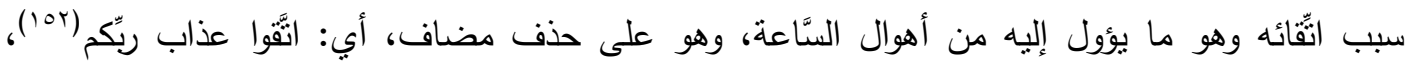

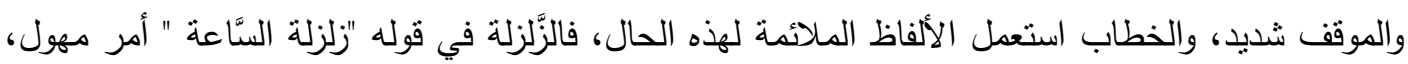

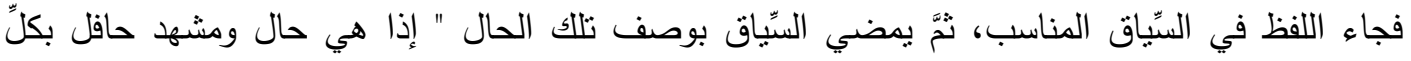
مرضعة ذاهلة عمّا أرضعت، تنظر ولا ترى، وتتحرَّك ولا تعي، وبكلٍ حامل تسقط حملها للهول المروِّع 


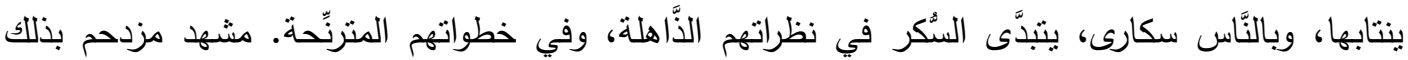

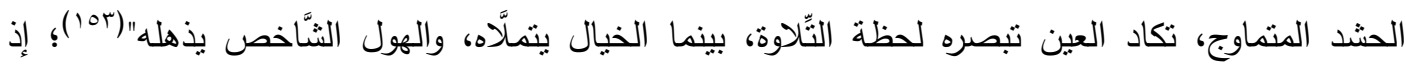

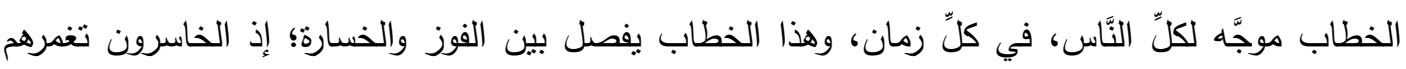

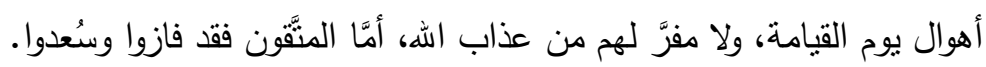

فالسيّاق أو سياق الحال ضروريٌّ جدّاً في فهم النُصوص، فبنية النَّصِّ مرتبطة بسياق الحال / المقام

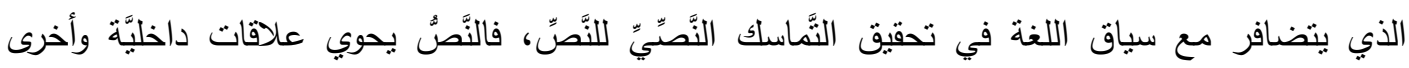

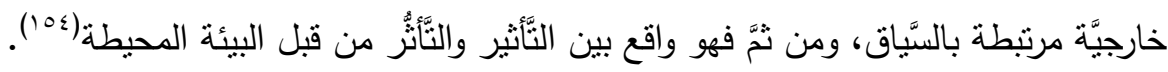




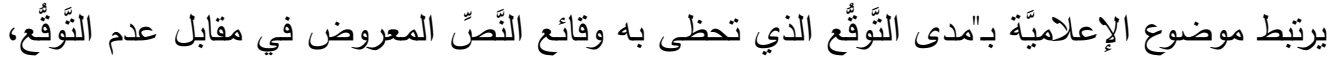

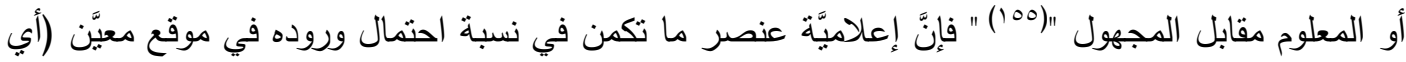

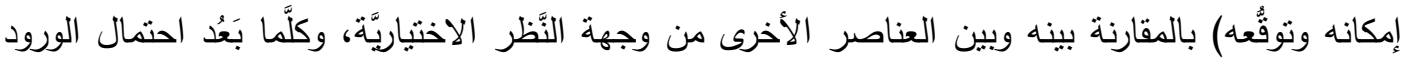

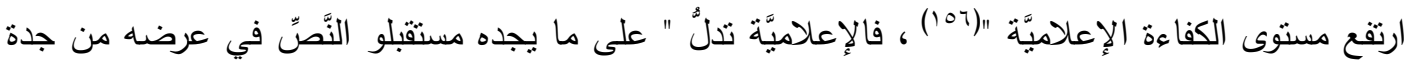

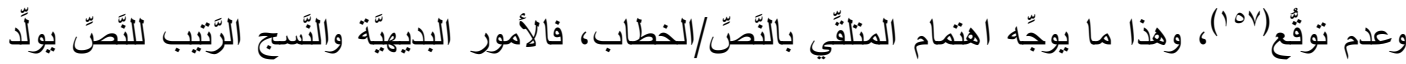

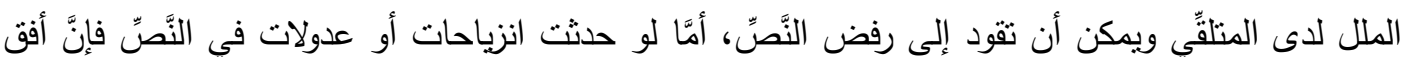

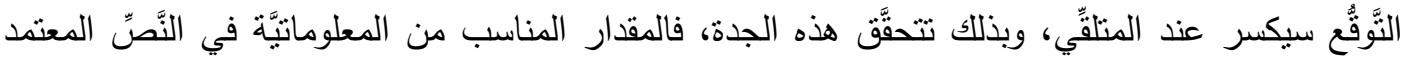

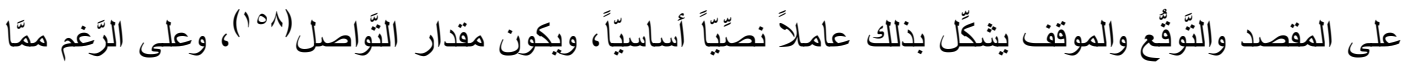

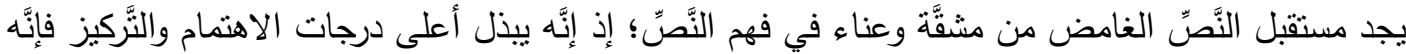

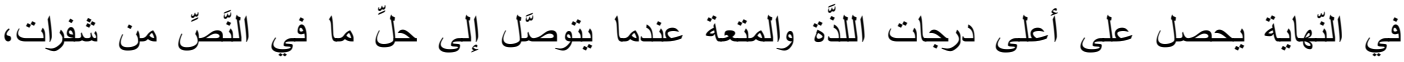

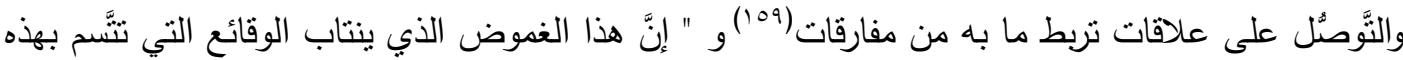

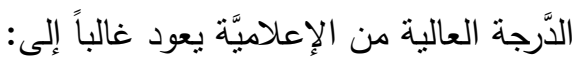

/ / الانقطاعات: بمعنى الحذف، أو عدم وجود مادَّةٍ ما.

r/ المفارقات: بمعنى أنَّ الأنماط الني ترد في النَّصِ تكون مختلفة عن أنماط المعرفة المختزنة "(•").

وتتجلَّى الإعلاميَّة في خطاب النَّصر في القرآن الكريم في صور وتراكيب وألفاظ عديدة ، فمنها ما جاء

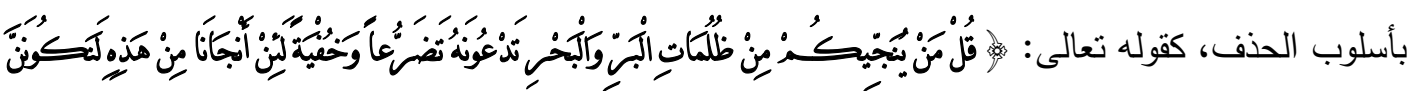

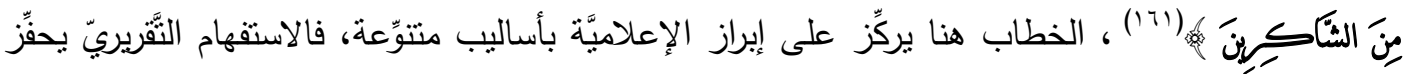

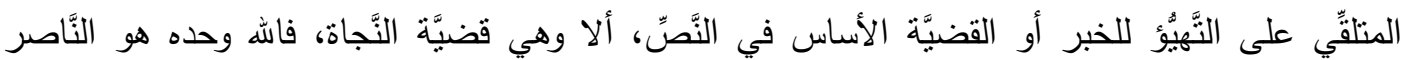

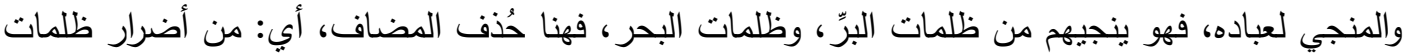

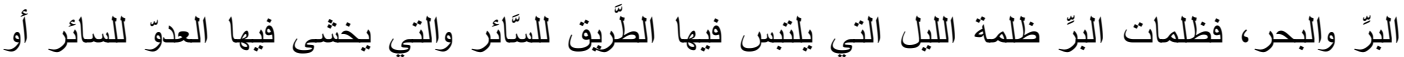
القاطن، أب: ما يحصل في ظلمات البرّ من الآفات، وظلمات البحر يخشى فيها الغرق والضَّلال والعدوّ. 


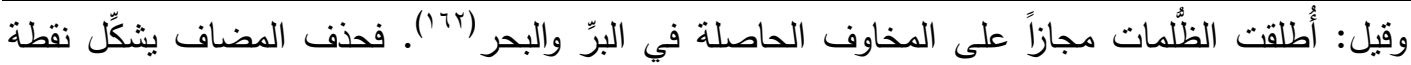
ارتكاز لقيمة المعلومة الواردة في الخطاب، والتي يلتمسها المتلقّي من خلال القرائن والأدلَّة التي تعبنه على ملء فراغات النَّصِّ. وهناك محذوف آخر في هذا النَّصِّ المبارك، في قوله "لئن أنجانا" في جملة في محلّ نصب بقول محذوف، أي: قائلين • وحذف القول كثير في القرآن الكريم إذا دلَّت عليه قربنة الكلام(بآ)، وهذه

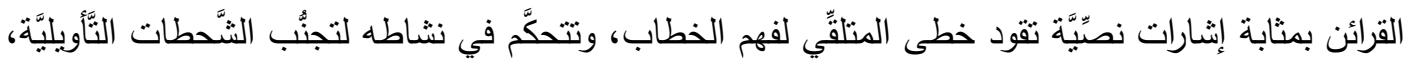

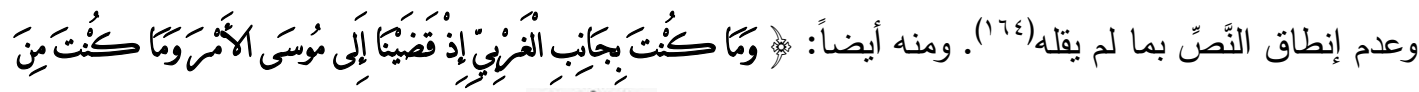

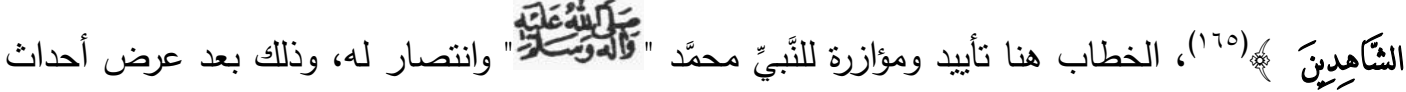
كثيرة من قصنَّة النَّبِِ موسى " عليه السَّلام " لم يشهدها رسول الله، عبَّرت عنها الآيات السَّابقة من سورة القصص، فوقع الحذف في قوله "وما كنت من الثنَّاهدين "، وهناك محذوف تقديره: ما كنت من الثَّاهدين لهذه الأحداث، والحذف هنا ينرك للمتلقِي ذهنه أن يتفاعل مع النَّصّ؛ لتقدير هذه المحذوفات، وهو يعتمد في

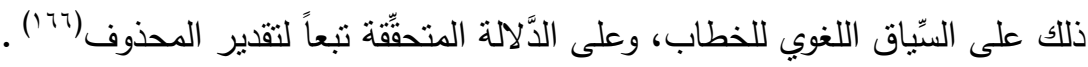

ويكثر الحذف في القصص القرآنيّ؛ ذلك أنَّ القرآن الكريم يميل كثيراً إلى لغة الإيجاز ، وهذا الإيجاز

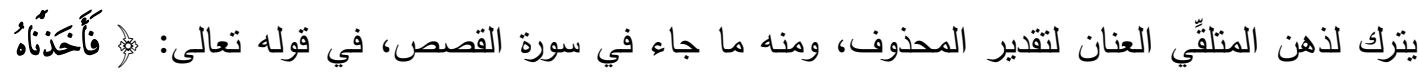

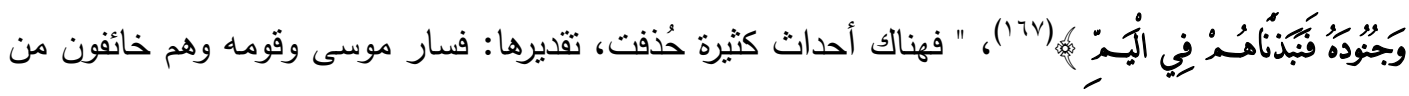
فرعون وجنوده، ثنّ اتَّعه فرعون وجنوده، فأمر الله بضرب البحر بالعصا، فكان كلّ فريق كالطوّد العظيم، وعبر موسى وقومه آمنين، ثنّ اتَّعه فرعون وجنوده، فأخذناه وجنوده فنبذناهم في اليمّ "(171) ، فالإعلاميَّة هنا جاءت بدرجة عالية تبعاً لآليَّة الحذف، فالنَّصٌُ القرآنيُّ زاخر بالاستعمالات الجديدة للغة، ممَّا بثير اهنمام المتلقيّ، ويدفعه إلى القراءة الاستتباطيَّة التي تخرج من النَّصِّ معاني جديدة ممَّا يرفع من درجة إعلاميَّة

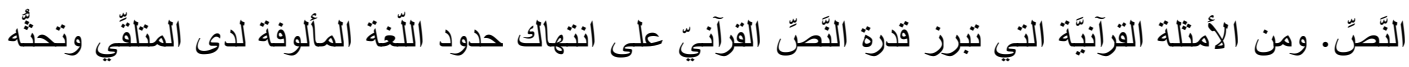

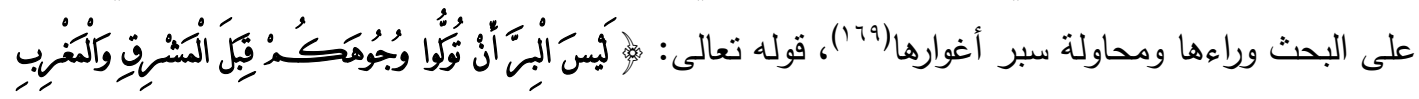

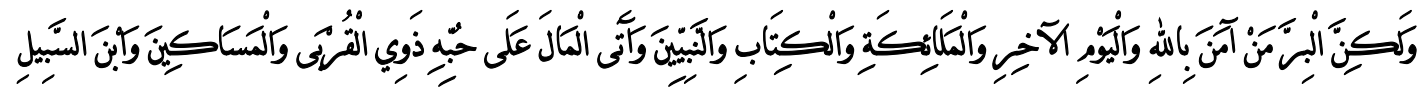

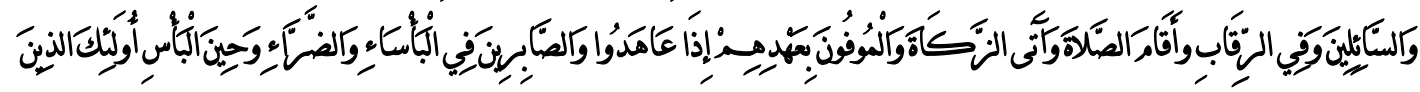




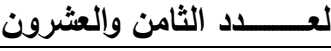

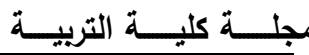

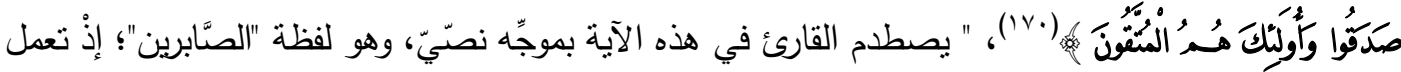
كمثير ومنبِّه تستفزٌ وعيه وفكره وتحوِّل أفقه؛ لأنَّه سيتفاجأ بورودها منصوبة وليست مرفوعة ممَّا يسنلزم

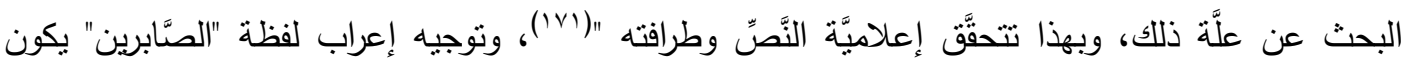
على أوجه: يكون "والموفون" رفعاً عطفاً على "من"، و "الصَّابرين" على المدح أي: وأعني الصَّابرين، ويكون "الموفون" رفعاً بمعنى: وهم الموفون مدحاً للمضمرينَ، و "الصَّابرين" عطفاً على ذوي القربى، ويكون "الموفون" وندين

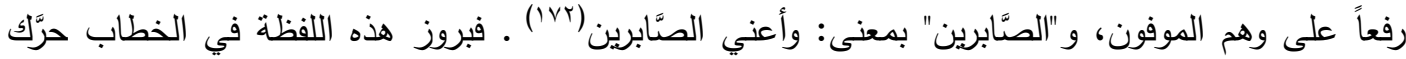
انتباه المتلقيّ ودفعه إلى الغوص في التَّحقيق من أجل الوقوف على الغرض الذي سيقت لأجله، فكسر حدود اللغة أكسب هذا الخطاب إعلاميَّة ذات كفاءة عالية.

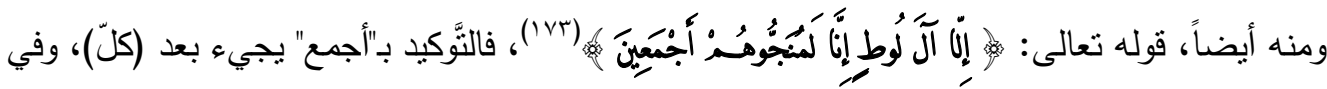
هذا الخطاب لم يذكر قبله (كلَّهم) لمَّا لم يكن المراد كلَّ واحد من الآية لم تحسن الزَّبادة في التَّكيد، بدليل

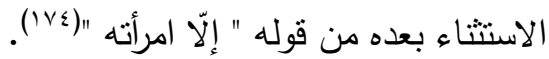

وتعتمد خطابات القرآن على الإيحاءات اللّنيّةّة المؤثِّرة التي ترفع من إعلاميَّة النَّصِّ، كما في قوله

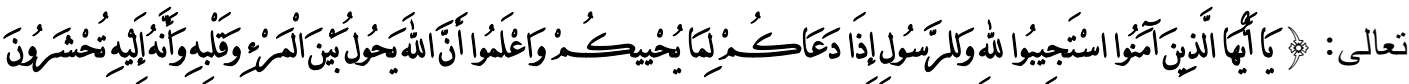

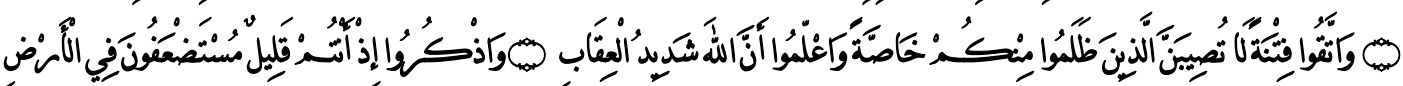

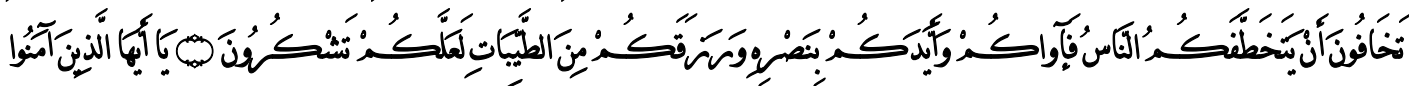

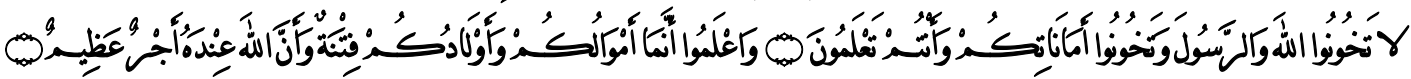

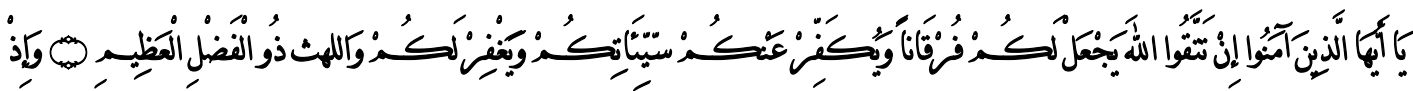

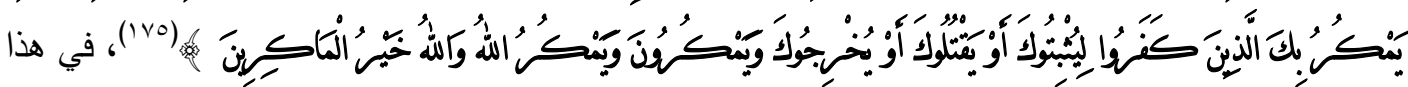
الخطاب كثير من الإيحاءات اللأنويَّة التي تلفت النَّظر، وترفع من مستوى الإعلاميَّة في الخطاب، فالخطاب هنا يبدأ بالنّّداء الذي يشكّل أكبر وسيلة جذب للمنلقيّ، وهو يصف الفائزين بصفة لطيفة تدلٌ على حالهم، وهي (الذين آمنوا) فهم قد استمسكوا بأقوى مسبَّب للنَّصر والنَّجاة، ويأتي الأمر بـ(استجيبوا)، والاستجابة تكون لله، وللرسول (إذا دعاكم لما يحييكم)، و (دعا) يتعدَّى باللام، والمعنى هنا: " استجيبوا لله وللرسول إذا دعاكم 
إلىى إحياء أمركم "(1/7)، فاللام بمعنى "إلى" ويتعلَّق ب(استجيبوا)؛ فلذلك قدّره بـ(إلىى) حتَّى بتغاير مدلول اللام

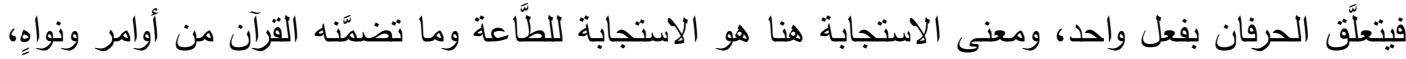

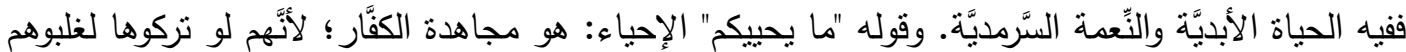

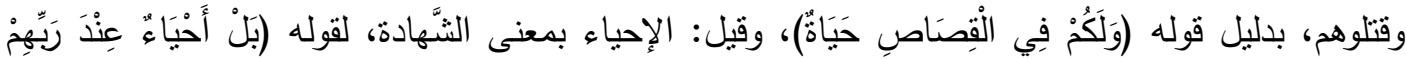

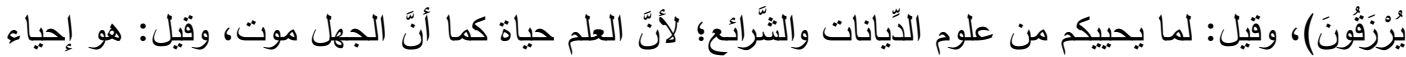

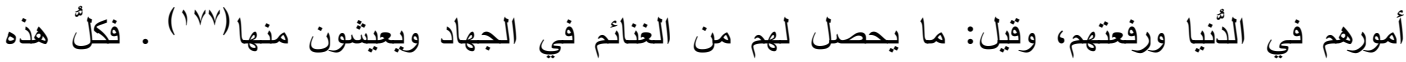

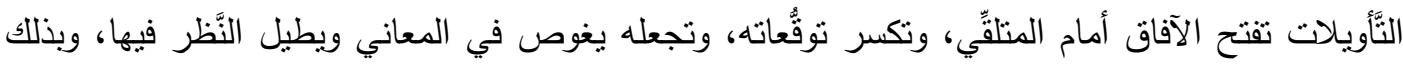

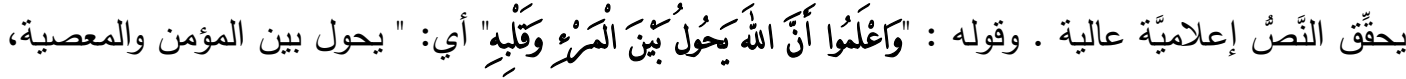

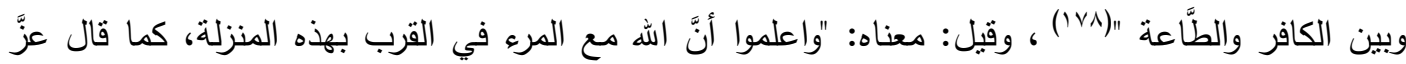

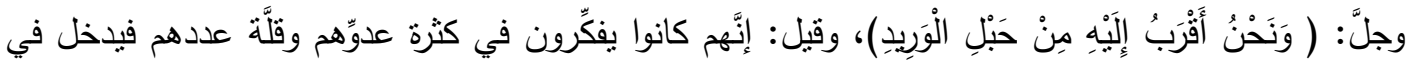

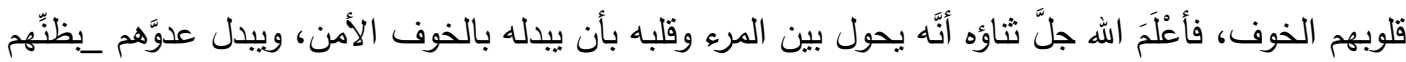

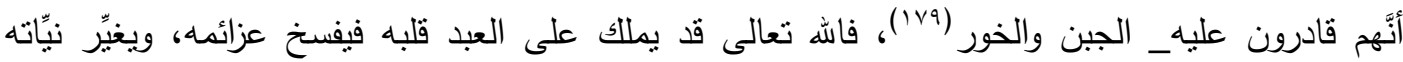

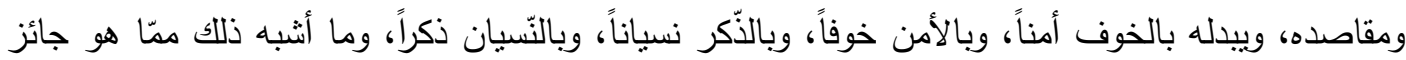

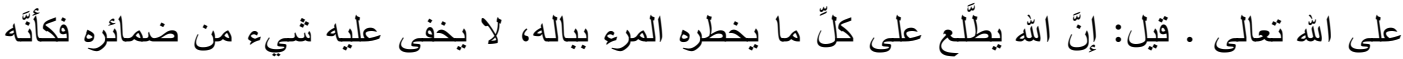

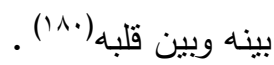
وقوله: (واتقَّوا فتنتة .......) أصل الفَتْنِ: إدخال الذَّب النَّار لنظهر جودته من رداءته، وجعلت الفتنة

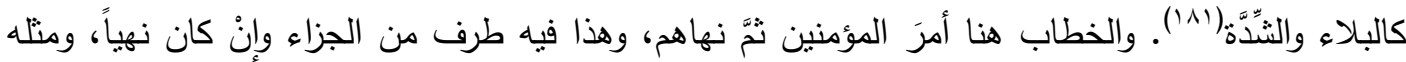

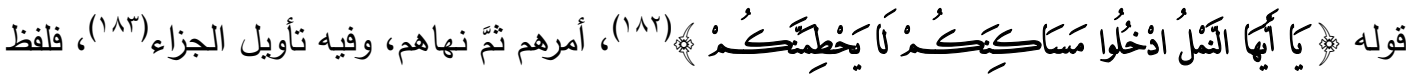

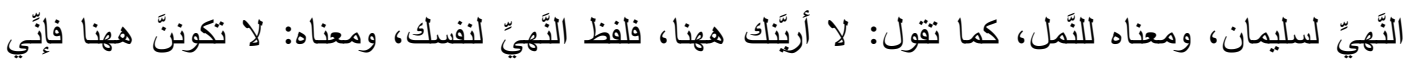

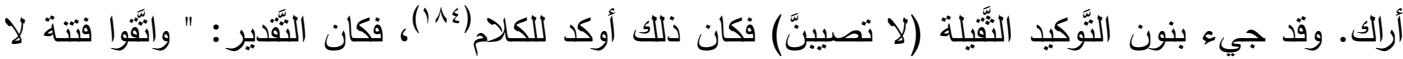

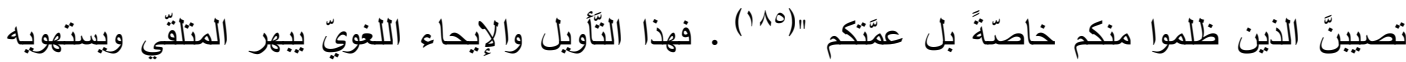
للبحث عن المعنى المقصود(T/1). وقوله : (واذكروا إذ أنتم قليل ) أي: في العدد، والجملة الاسميَّة للإيذان

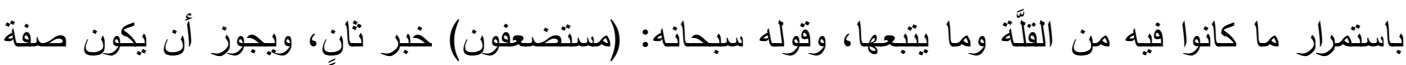

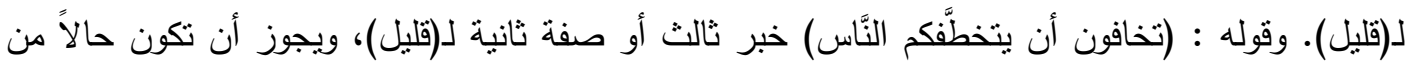

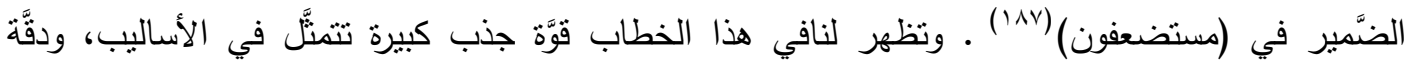




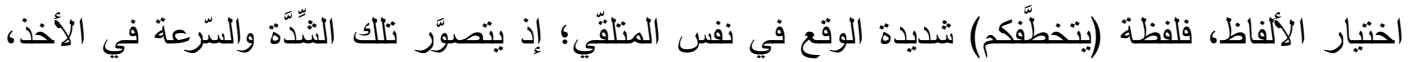

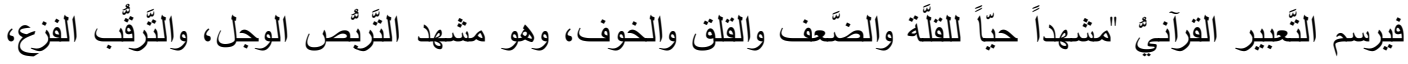

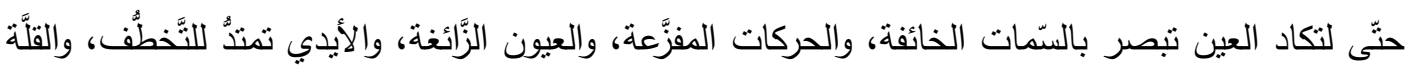

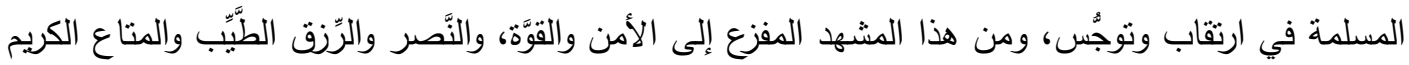

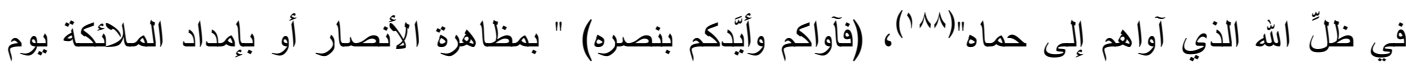

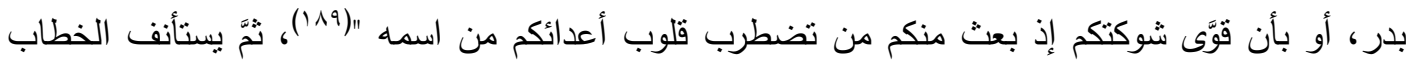

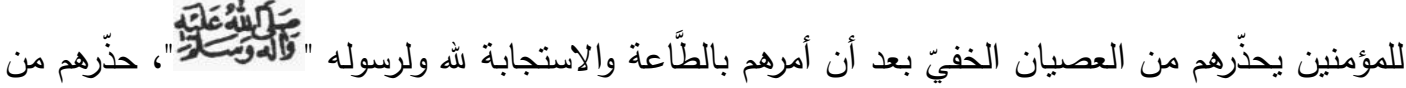

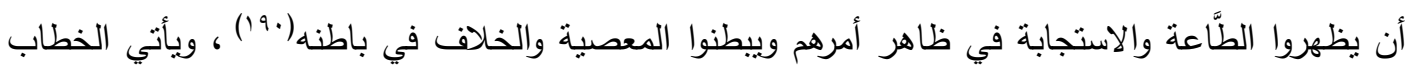

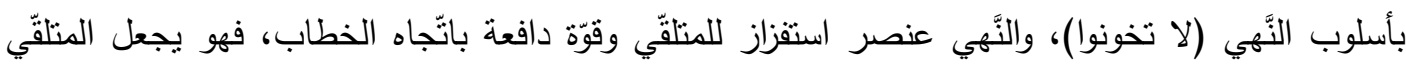
يسترسل في الإصغاء لما نُهي عنه، بحيث ينصبُّ اهتمامه على فحوى الخطاب والتَّركيز في مراميه.

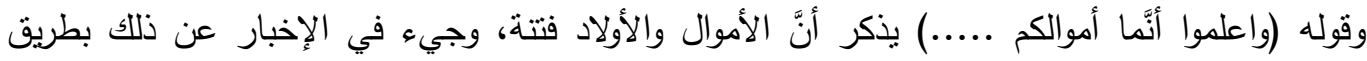

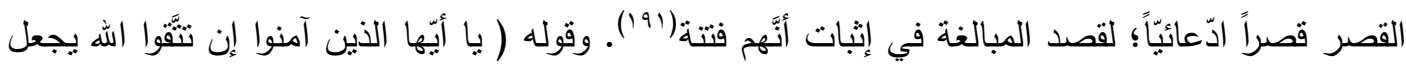

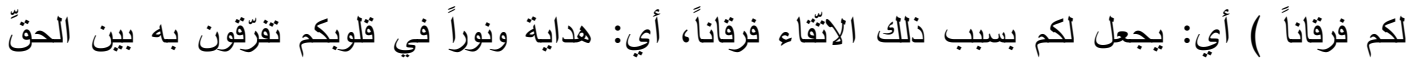

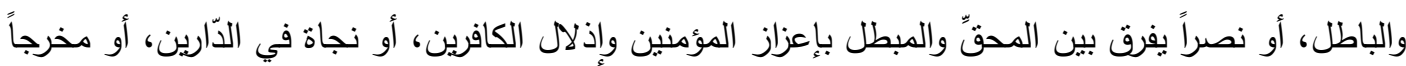

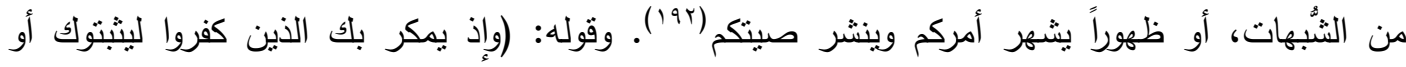

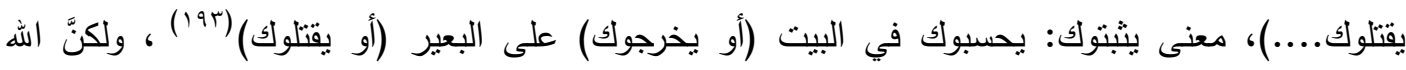
ناصرك عليهم، فهو خير نصير. لاحظنا في النَّصِّ المبارك أساليب نحويَّة وبلاغيَّة لها عدَّة وجوه في التَّكبيب واللفظ الواحد؛ وذلك لإفادة

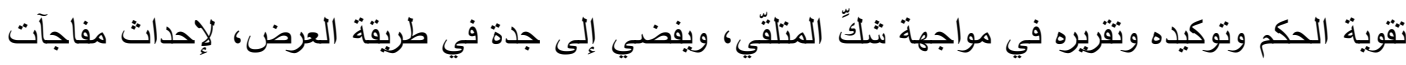

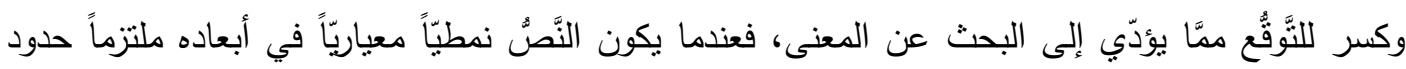

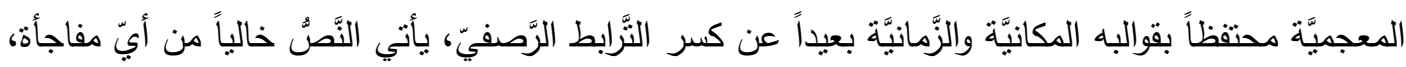

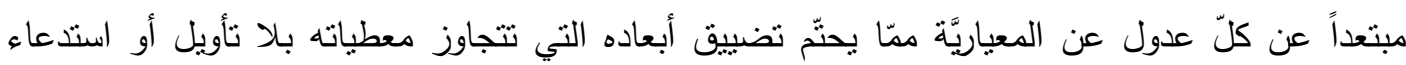

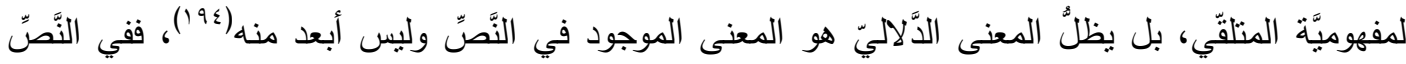

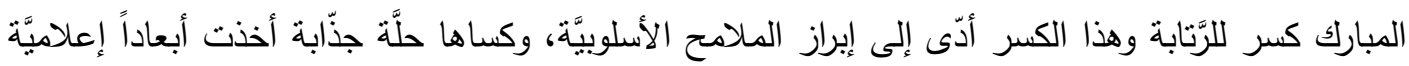
عالية لاى المنلقيّي 


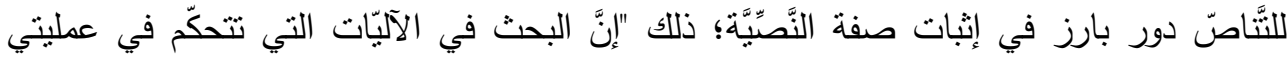

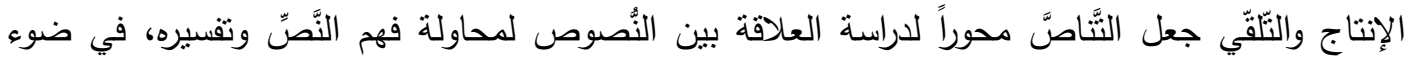

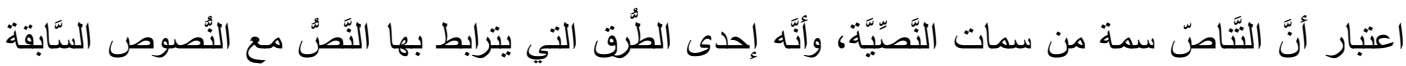

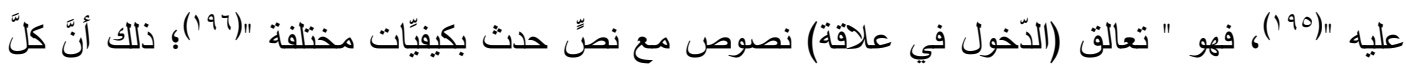

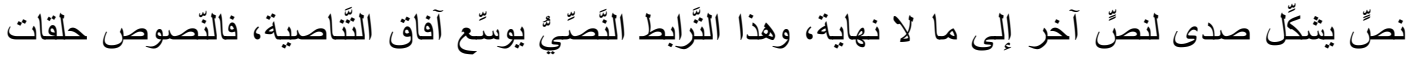

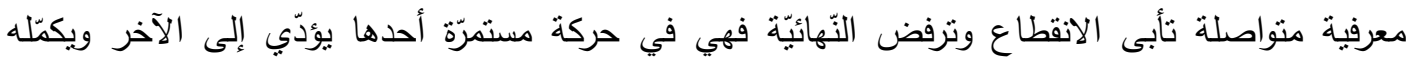

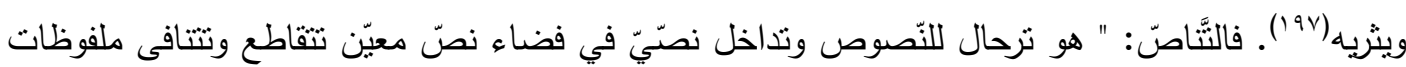

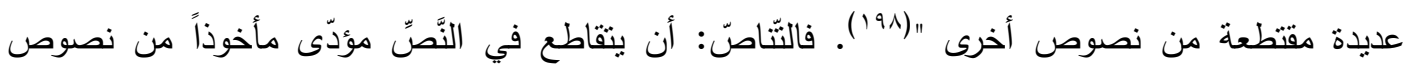

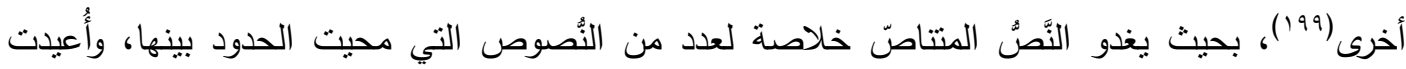

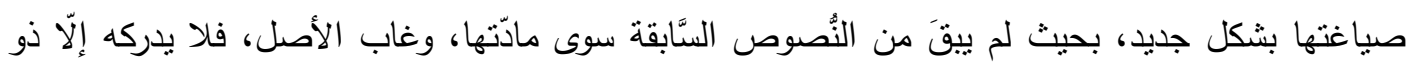

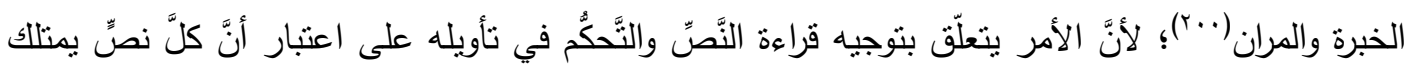
علاقة نسب. والتُّاصُ يبدو في ثلاثة فضاءات: يتحدَّد الفضاء الأوَّل كمكان لتحديد الملفوظات الآثية من

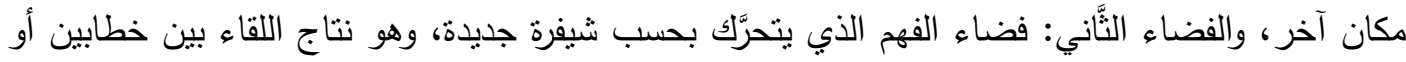

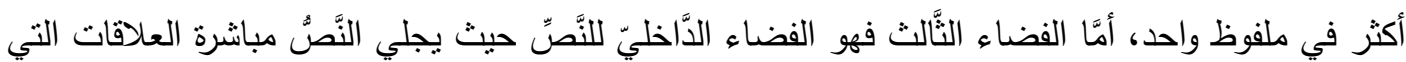

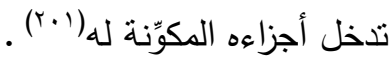

والنُصوص في القرآن الكريم تتقاطع وتتسلسل في سلاسل متماسكة من المعاني والقضايا؛ لذا فهو زاخر

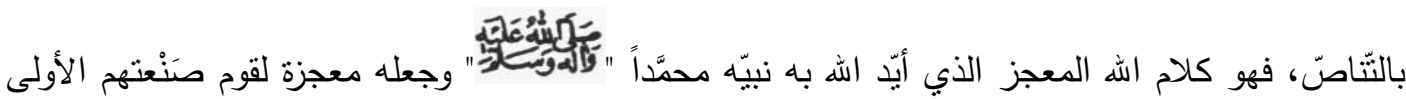

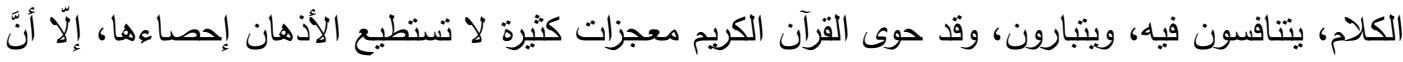

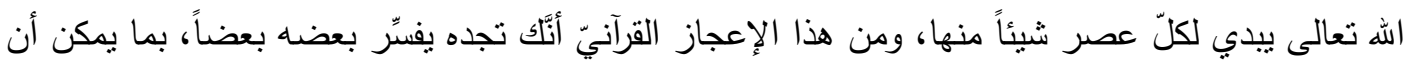

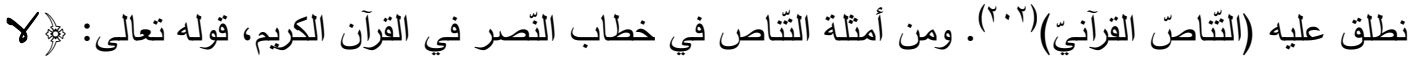

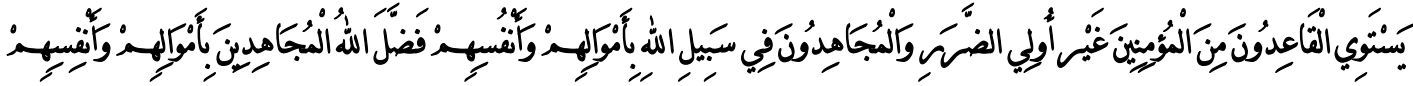

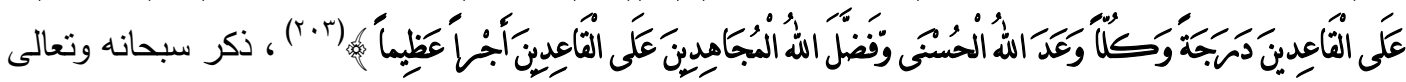


في هذه الآية الكريمة "أنَّهَ فضّل المجاهدين في سبيل الله بأموالهم وأنفسهم على القاعدين درجة وأجراً عظيماً، ولم يتعرَّض لتفضيل بعض المجاهدين على بعض، ولكنَّه بيَّن ذلك في موضع آخر ، وهو قوله: له كَنتّوي

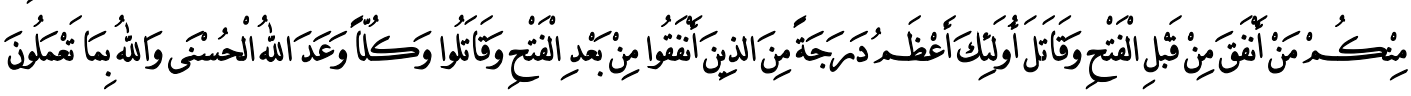

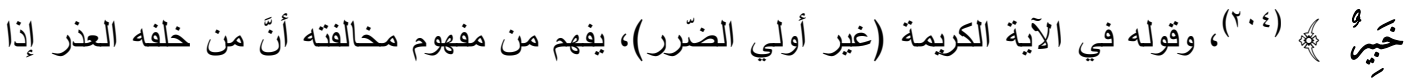
كانت نيَّته صالحة يحصِّل ثواب المجاهد"(r.0) .

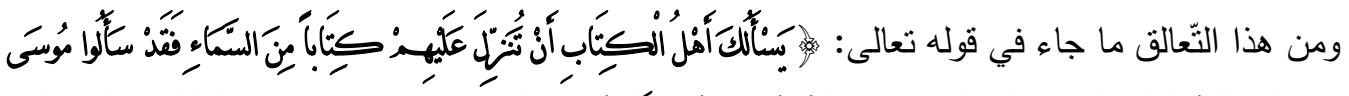

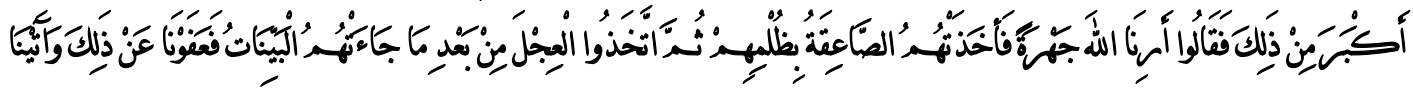

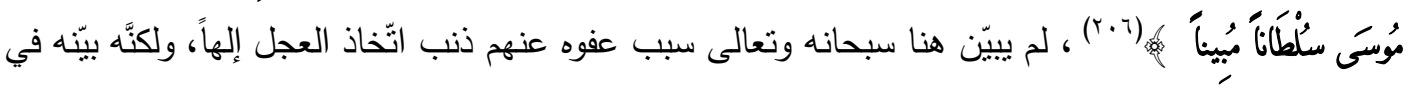

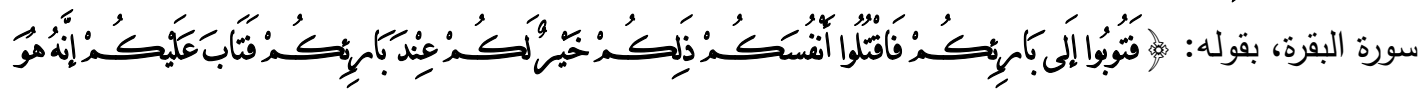

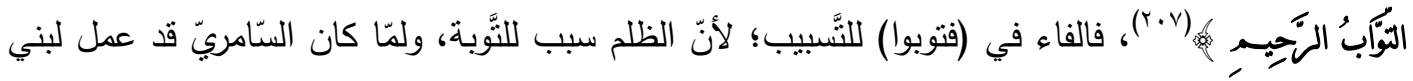
إسرائيل من حليّهم عجلاً ، قيل لهم : توبوا إلى بارئكم، أي: منشئكم وموجدكم من العدم(^•r)، وقوله: (فاقتلوا أنفسكم)، "فيه ثناثة أقوال: الأوّل: الأمر بقتل أنفسهم. الثّاني: الاستسلام للقتل. والثّالث: التّليل للأهواء. والأوّل هو الظّاهر، وهو الذي نقله أكثر النّاس، وظاهر الكلام أنَّهم مأمورون بقتل أنفسهم، فقيل: وقع القتل هكذا قتلوا أنفسهم بأيديهم. وقيل: قتل بعضهم بعضاً من غير تعبين قاتل ولا مقتول. وقيل: القاتلون هم الذين اعتزلوا مع هارون، والمقتولون عبّاد العجل. وقيل: القاتلون هم الذين كانوا مع موسى في المناجاة بطور سيناء، والمقتولون من عداهم "(ج.r)، فالنّصّ الثّاني امتداد للنّصّ للأوّل، فهو يتعالق معه في القضيّة نفسها؛

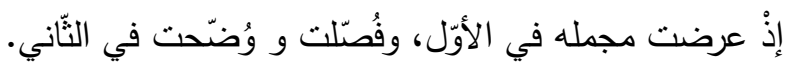

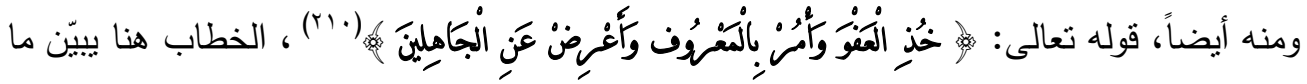
ينبغي أن يُعامل به الجهلة من شياطين الإنس والجنّ، "فييّن أنّ شيطان الإنس يُعامل باللين وأخذ العفو،

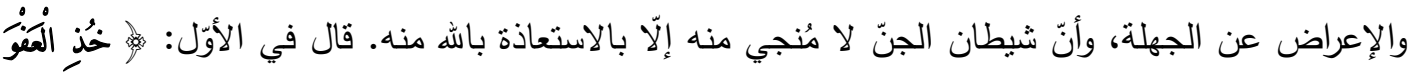

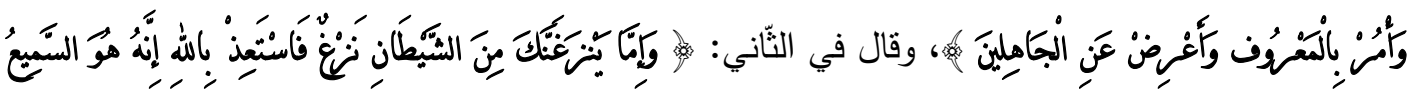




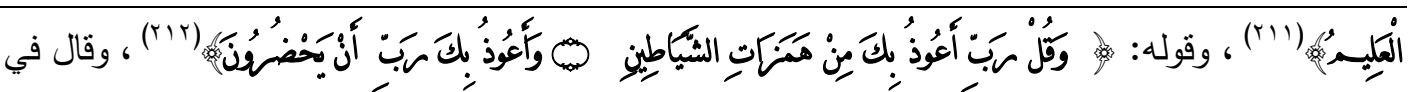

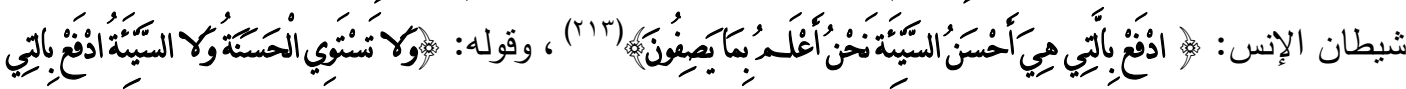

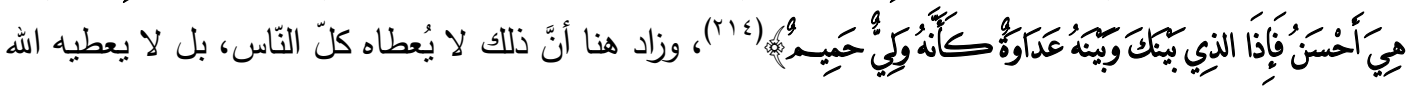

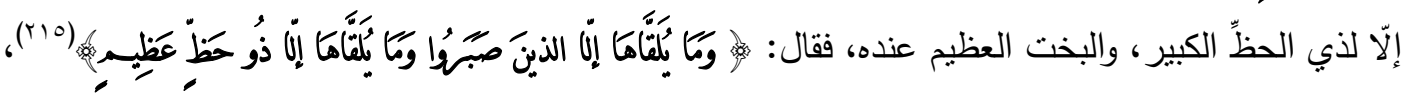
فهذه النُصوص كلُّها مرتبطة مع بعضها البعض، وهذا الارتباط يوثِّق المعرفة التي تعرضها النّصوص من خلال الفهم والاسترجاع إذا كانت مزاوجة لأنماط المعرفة المختزنة، أو إذا كانت قابلة للتَّعلُق بالمدخلات الرَّيَيسة في أحد الأنماط الكليَّة، وقد يحدث إحداث تغييرات على المعرفة التي يعرضها النّّن في عمليّة الاسترجاع من أجل إحداث مزاوجة أفضل مع أنماط المعرفة المختزنة، كما قد تتعرَّض العناصر المتمايزة في

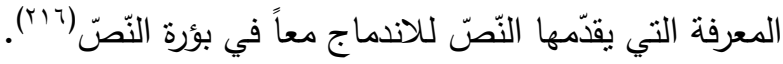

وأكثر صورة يبرز فيها الثّاصّ في القرآن الكريم، هي القصص القرآنيّ؛ إذْ ثُذكر القصنَّة في مواضع

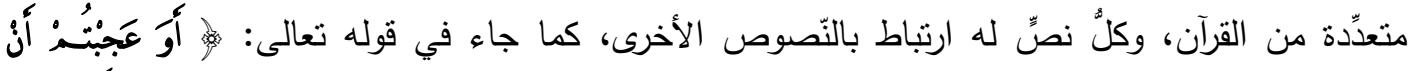

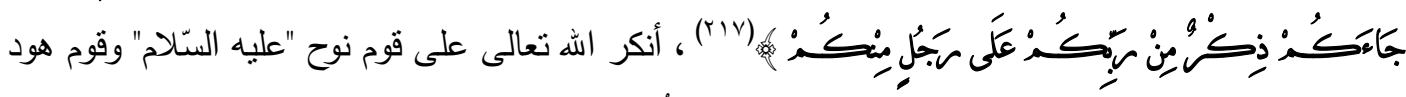
"عليه السّلام" عجبهم من إرسال رجل؛ وبيَّن في مواضع أُخر أنَّ جميع الأمح عجبوا من ذلك. قال في عجب مبر

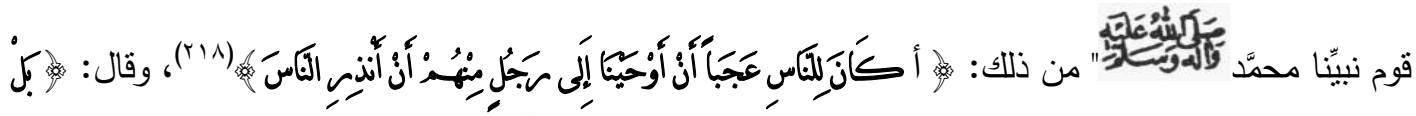

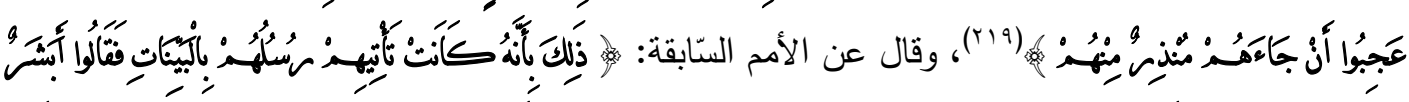

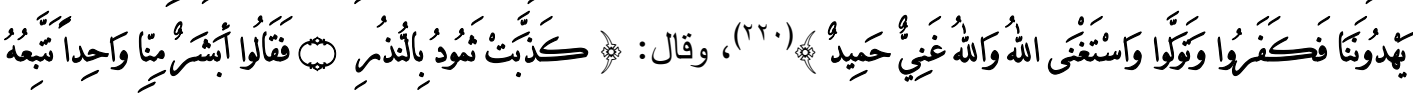

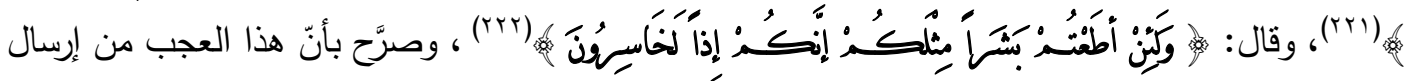

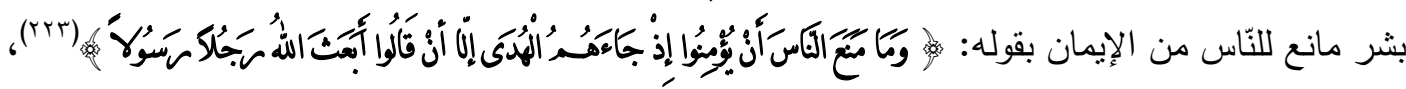
وردَّ الله عليهم ذلك وانتصر لرسله في نصوص كثيرة، كقوله:

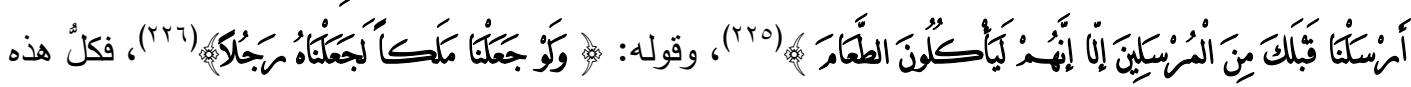
النُّصوص متشتابهة في الدَّلالة، وقد جاءت في أماكن متفرِّة ومتباعدة من القرآن الكريم؛ إذِ انبثق معنى واحد 
في نصِّ معيَّن، وتتاسلت منه قضايا وأحداث لغويَّة ودلاليَّة، نؤكِّ الرَّصف المتين للخطابات الإلهيّة، ومن

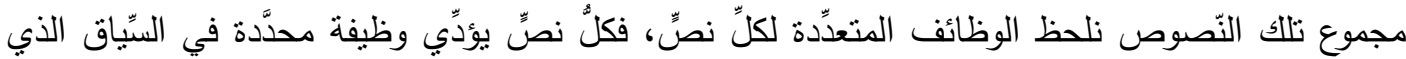
جاء فيه؛ إذِ التَّاص " فسيفساء من نصوص أخرى أُدمجت فيه بتقنيَّات مختلفة "(rVV) .

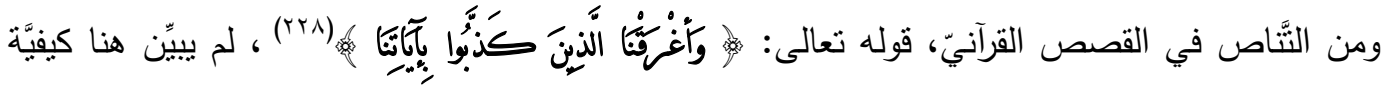

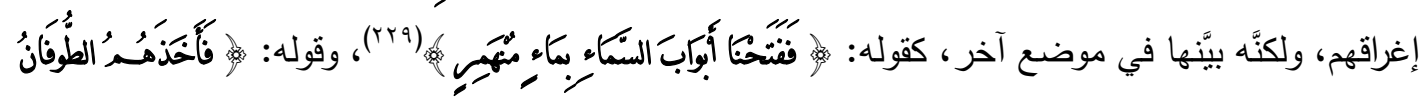

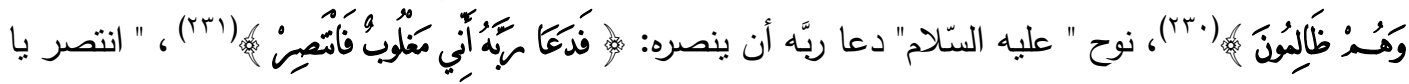
ربّ لرسوللك الذي كذّبوه، وانتصر لدينك الذي حاربوه، وانتصر لأوليائك الذين اضطهدوهم، وانتصر للحقٍ

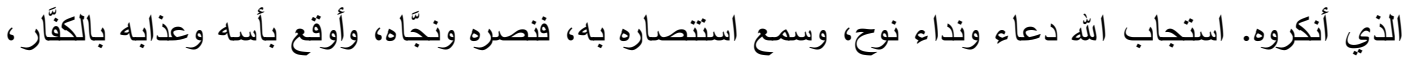

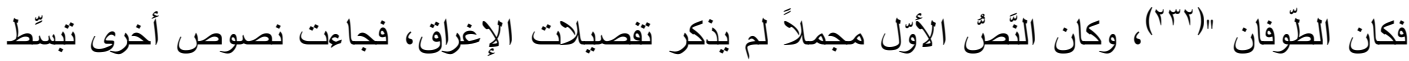
وتوضِّح هذا المجمل، وبذلك يكون نسيج القصِّ منواصلاً يربط أجزاء القصَّة في سرد محكم، منتاسق

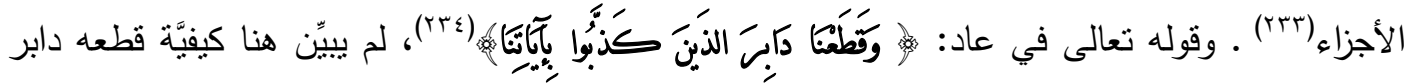
(عاد) ولكنَّه بيَّنه في مواضع أُخر ، كقوله:

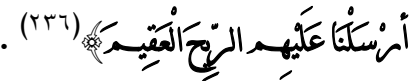

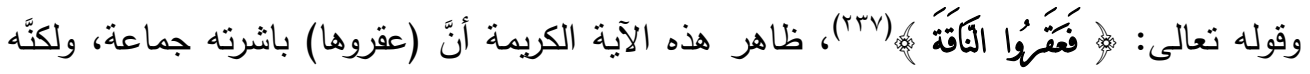

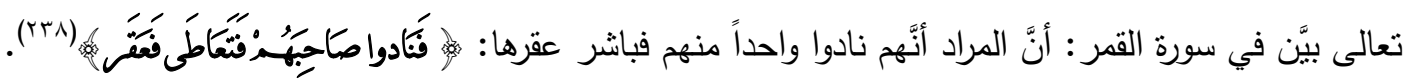

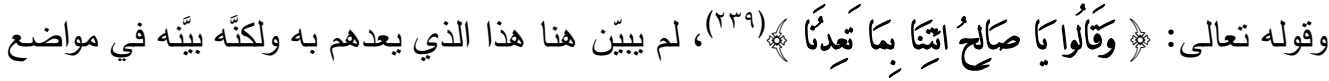

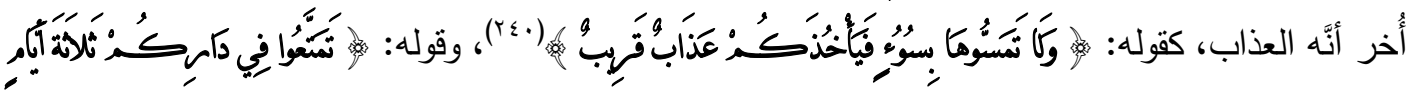

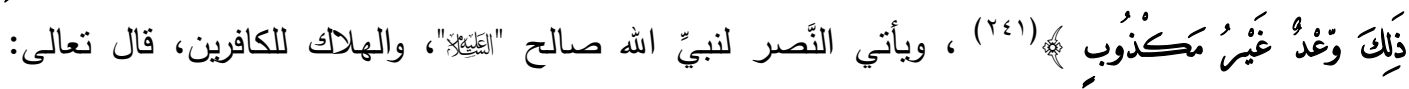

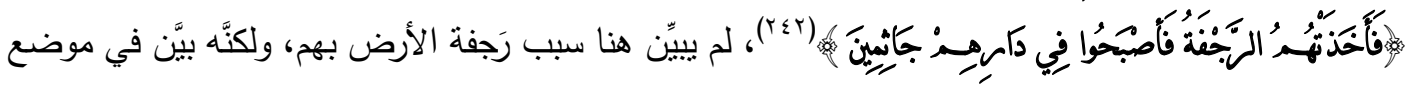




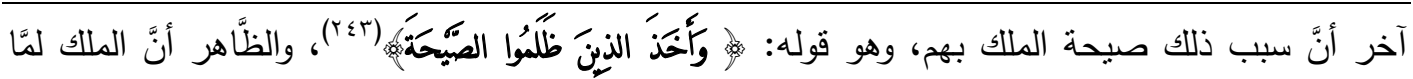
صاح بهم رجفت بهم الأرض من شدَّة الصنَّيحة، وفارقت أرواحهم أبدانهم (ع ب) .

فالتَّاص في هذه القصص وغيرها يؤكّد حبك النَّصِّ، وفي الوقت نفسه بشكّل عنصر جذب قويٍٍ

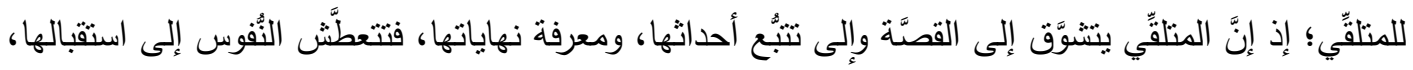
وتتوجَّه الآذان إلى سماعها. وقد استعمل القرآن القصَّة للعظة والعبرة، وتسلية للنبيّ "صلّى الله عليه وآله وسلم" كما أمر الله نبيَّه في كتابه أن يقصنَ على قومه القصص؛ ليكون لهم فيها عبرة وموعظة، وليتخذوا منها

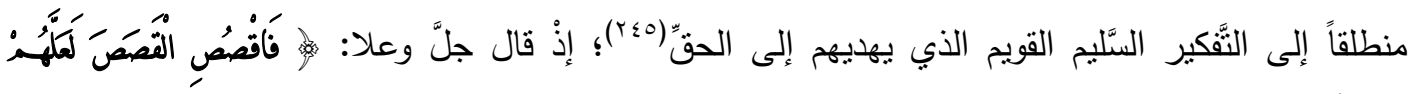

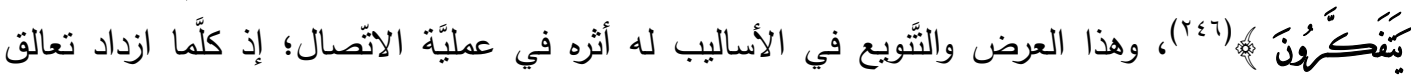
النُّصوص ازداد الثَّأثنر في المتلقِي وازدادت فاعليَّة الخطاب. 
الاتُّسال اللُّويّ في القرآن الكريم، دراسة تأصيليَّة في المفاهيم والمهارات، فهد محمَّد الثَّعابي الحارثي، منتدى

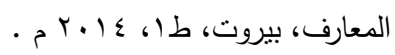

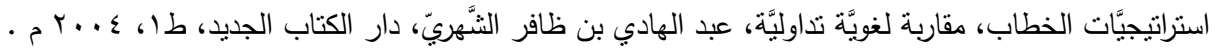

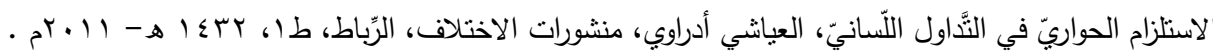

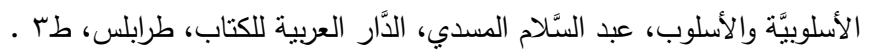

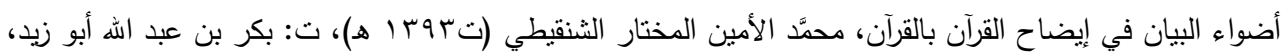

$$
\text { دار عالم الفوائد . }
$$

الإعجاز في نسق القرآن، دراسة للفصل والوصل بين المفردات، محمَّد الأمين الخضري، مكتبة زهراء الثَّرَ، القاهرة،

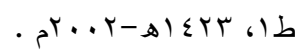

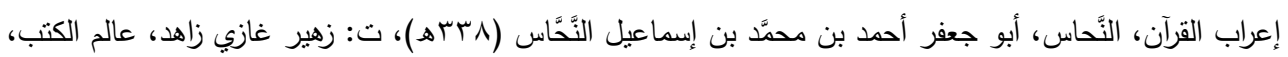

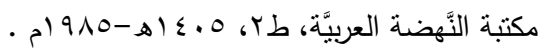

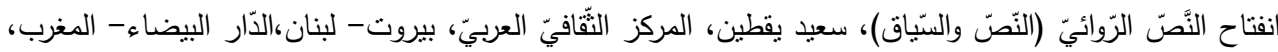

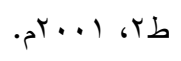

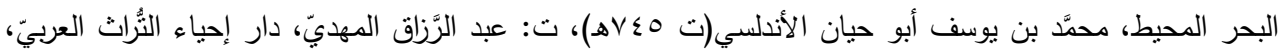

$$
\text { بيروت البحز ل }
$$

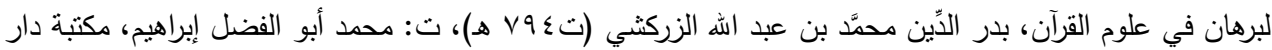
التّراث، القاهرة .

تاج العروس من جواهر القاموس، محمَّد مرتضى الحسيني الزبيدي، ت: عبد الكريم الغرباوي، مطبعة حكومة الكويت،

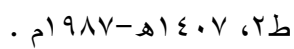

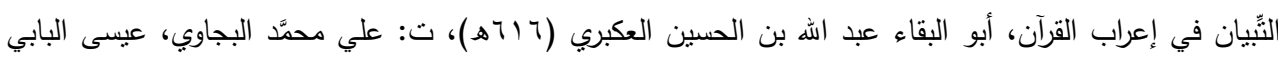
حلبي وشركاه . التَّرير والتَّوير (تحرير المعنى السديد وتتور العقل الجديد من تفسير الكتاب المجيد)، محمَّد الطَّاهر بن عاشور

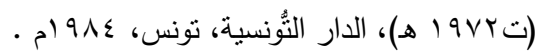

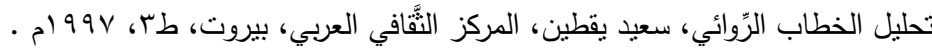

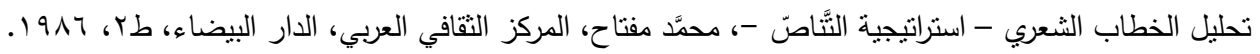

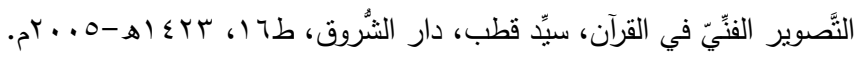

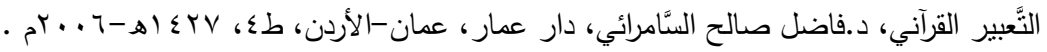




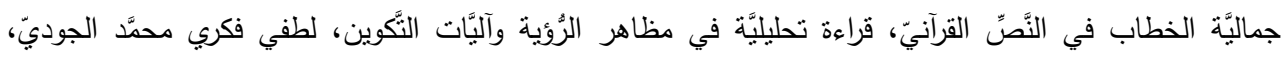

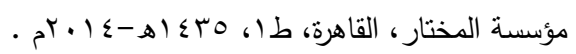

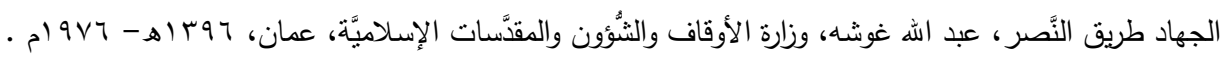

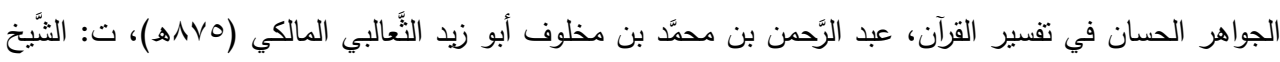

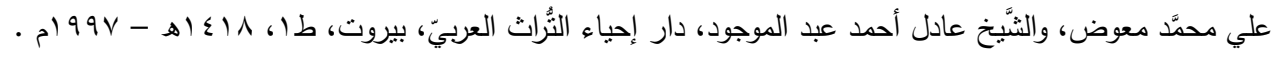

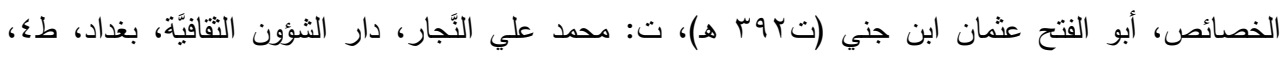

. 199.

الخطاب القرآنيّ دراسة في العلاقة بين النَِّّ والسيّاق، خلود العموش، جدارا للكتاب العالميّ، عمَّان-الأردن ، طا،

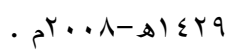

الخطاب وخصائص اللُغة العربيَّة، أحمد المنوكّل، دراسة في الوظيفة والبنية والنَّط، دار الأمان، الرِّباط، طا،

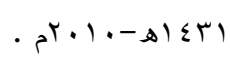

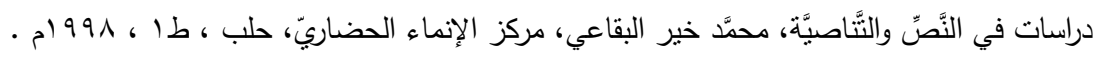

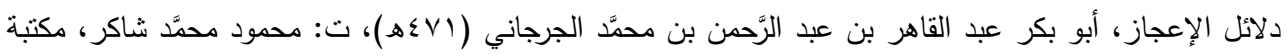

$$
\text { الخانجي، القاهرة . }
$$

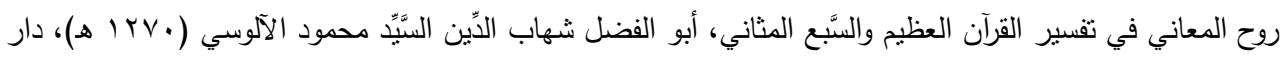

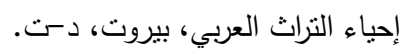

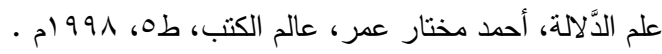

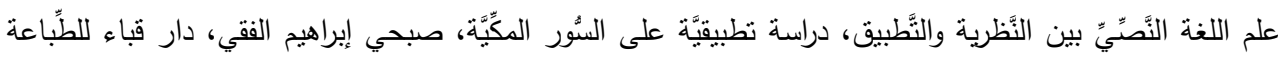

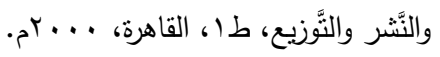

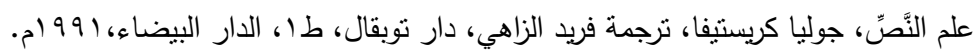

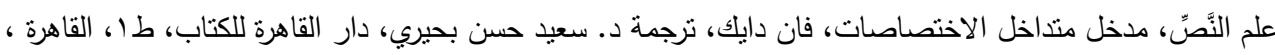

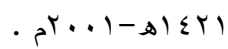

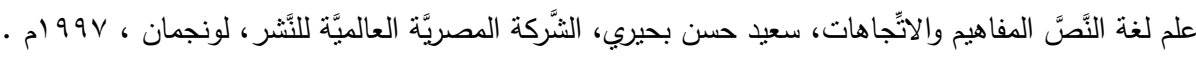

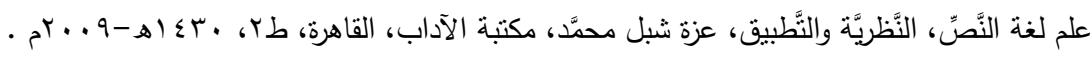

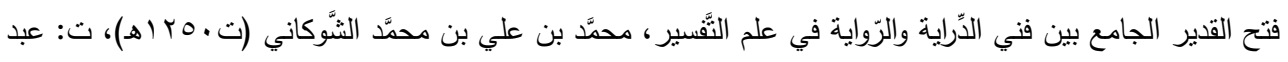

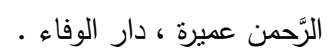

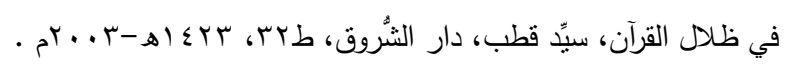

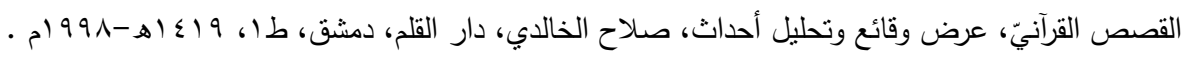


الكثَّاف عن حقائق غوامض التَّزيل وعيون الأقاويل في وجوه النَّزيل، أبو القاسم جار الله محمود بن عمر الزمخشري

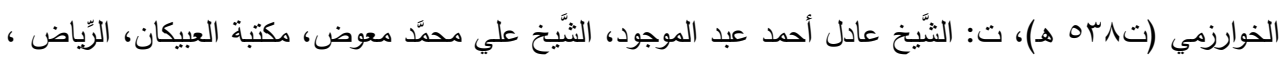
. مो99-ه

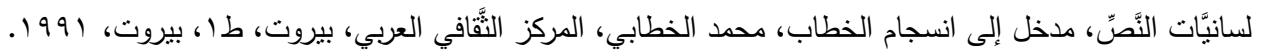

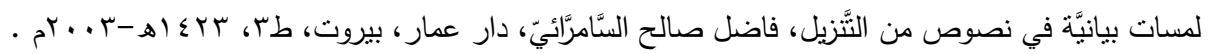

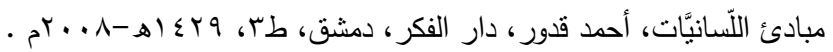

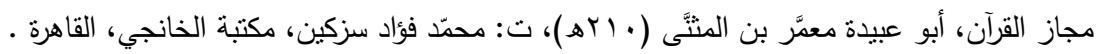

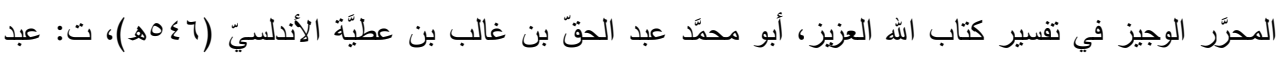

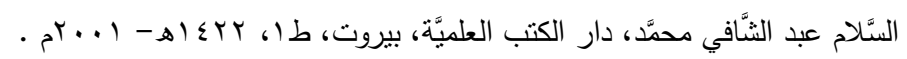

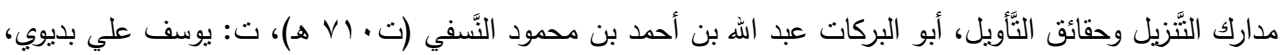

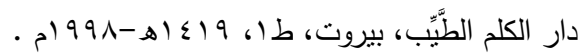
مدخل إلى علم النَّصِّ ومجالات تطبيقه، د. محمد الأخضر الصبيحي، منشورات الاختلاف، الجزائر، الدار العربية

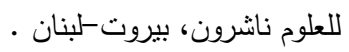
مدخل إلى علم النَّصِّ، مشكلات بناء النَّصِّ، زتسيسلاف واورزنياك، نرجمة: أ.د.سعيد حسن بحيري، مؤسسة المختار

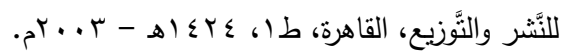

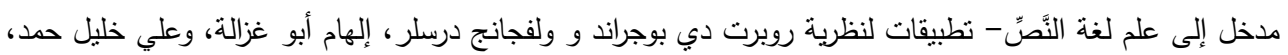

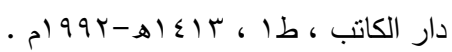

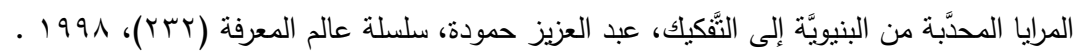

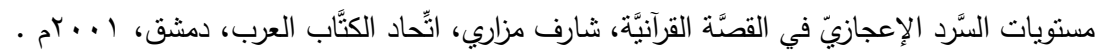

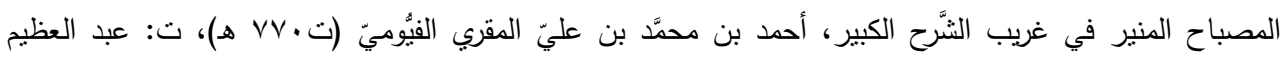

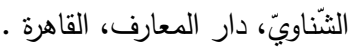

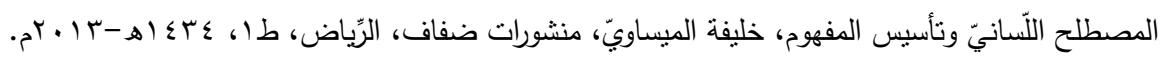

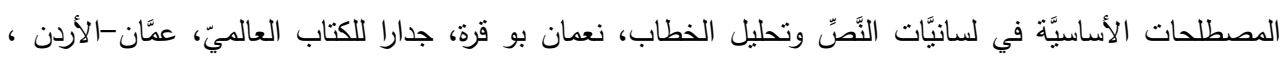

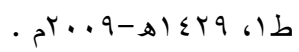
المصطلحات المفاتيح لتحليل الخطاب، دومنيك مانغونو، نرجمة: محمد يحياتن، الدَّار العربيَّة للعلوم ناشرون، بيروت-

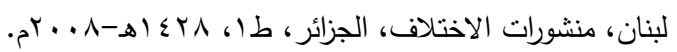

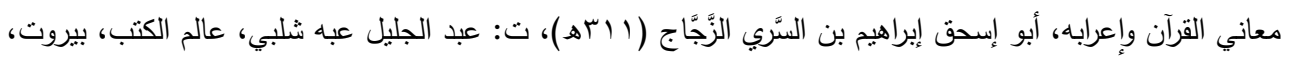

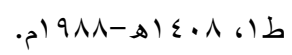

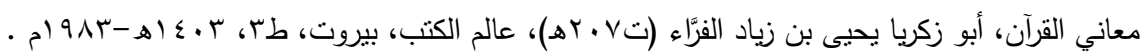

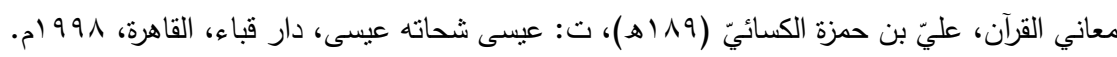




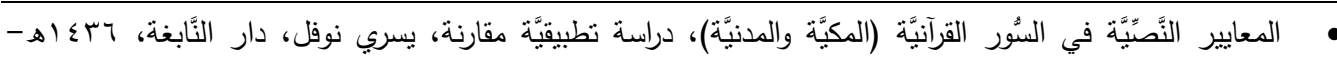

$$
\text { - مبرك }
$$

معترك الأقران في إعجاز القرآن، جلال الدّين عبد الرَّحمن بن أبي بكر محمَّد السيوطيّ (ت الو هـ)، ت: عليّ محمَّد

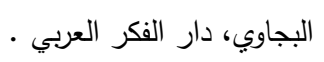

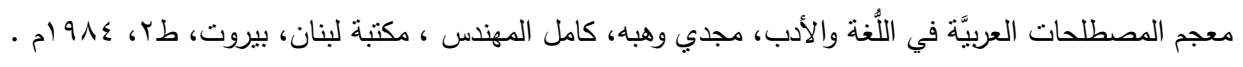

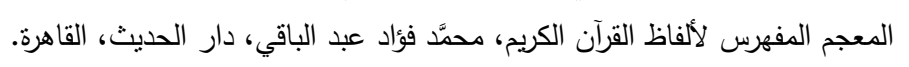

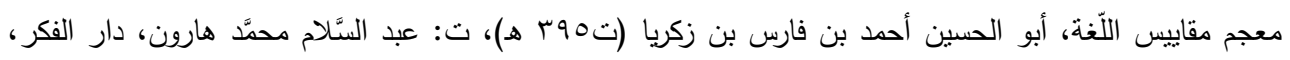

$$
\text { بيروت مبعن }
$$

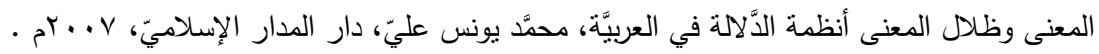

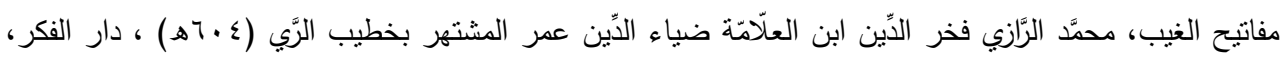

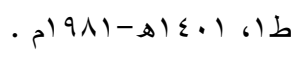

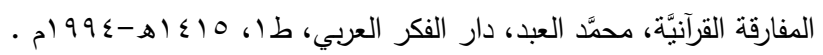

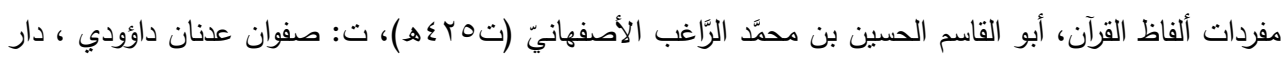

$$
\text { القلم، دمشق. }
$$

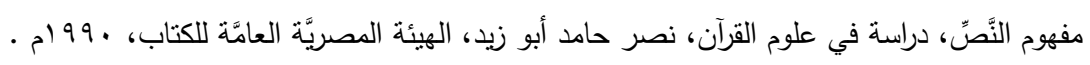

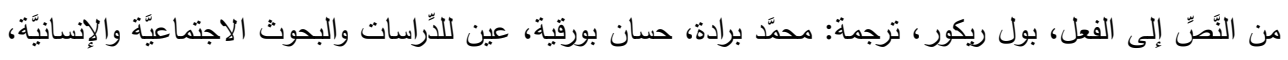

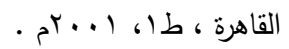

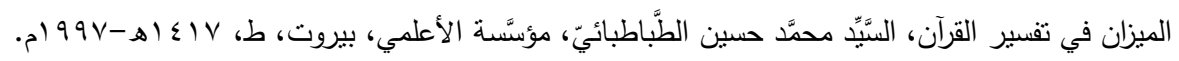

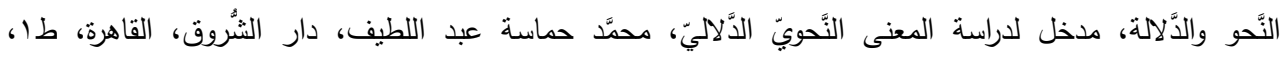

$$
\text { - مr...- }
$$

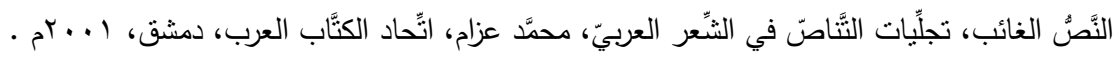

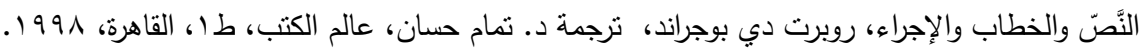

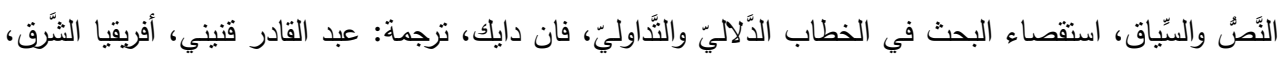

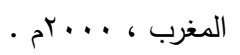

النَّظريَّات اللَّبانَّةّة الكبرى، ماري ، آن بافو، جورج إليا سرفاتي، ترجمة: محمَّد الرَّاضي، المنظمَّة العربيَّة للتَّرجمة، بيروت،

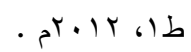
نظم الدُرر في تتاسب الآيات والسُّر ، برهان الدّين أبو الحسن إبراهيم بن عمر البقاعي (ت100 هـ)، مكنبة ابن تيمية،

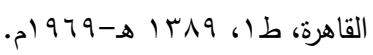

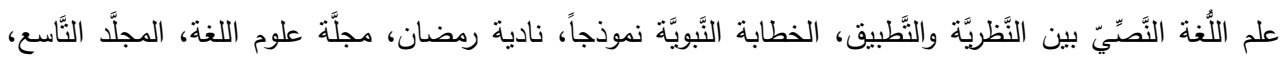

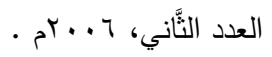




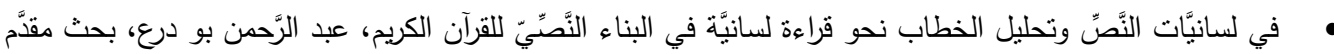

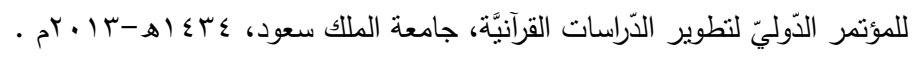

الأطاريح والمَّسائل الجامعيَّة:

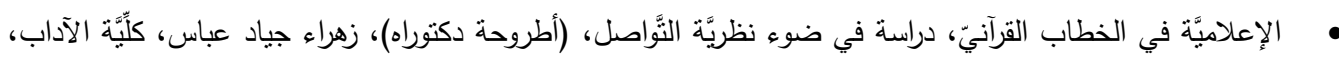

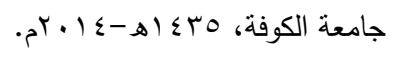

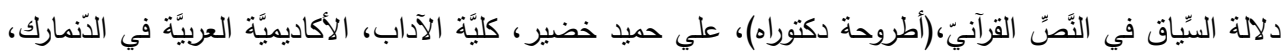

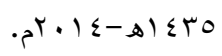

• الخطاب القرآنيّ، دراسة في البعد التَّاوليّ، (أطروحة دكتوراه)، مؤيَّد عبيد آل صوينت، كليَّة الآداب، الجامعة

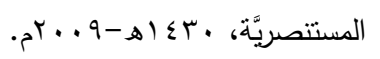

الهوامش

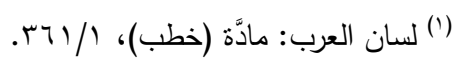

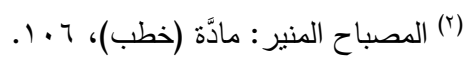

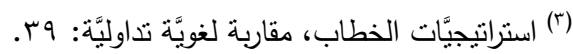

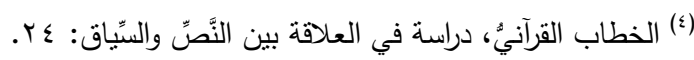

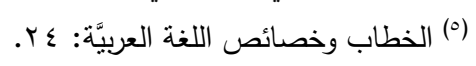

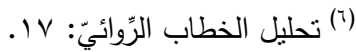

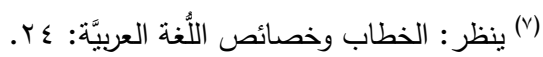

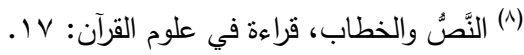

$$
\begin{aligned}
& \text { (9) }
\end{aligned}
$$

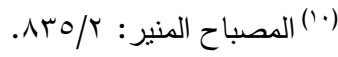

$$
\begin{aligned}
& \text { (") (1) ينظر : من النَّصُّ إلى الفعل: } 90 .
\end{aligned}
$$

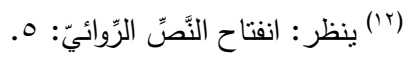

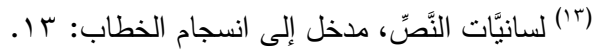

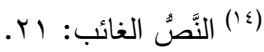

$$
\begin{aligned}
& \text { (10) }
\end{aligned}
$$

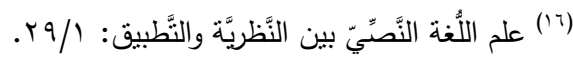

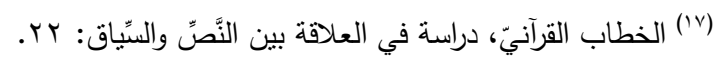

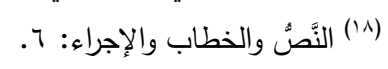

rᄉ 


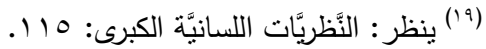

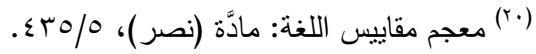

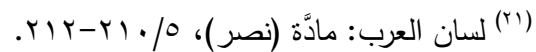

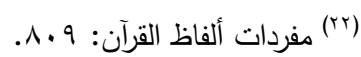

$$
\begin{aligned}
& \text { (r) } \\
& \text { (r ) المائدة/ (r) }
\end{aligned}
$$

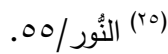

$$
\begin{aligned}
& \text {. }
\end{aligned}
$$

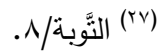

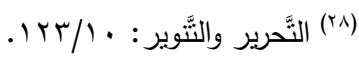

$$
\begin{aligned}
& \text { آل آل عمران/ (ra) }
\end{aligned}
$$

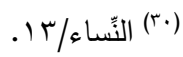

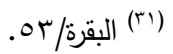

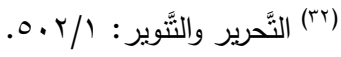

$$
\begin{aligned}
& \text { (ك) }
\end{aligned}
$$

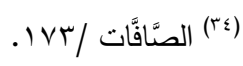

$$
\begin{aligned}
& \text {. r } 49 / \text { / البقرة (ro) }
\end{aligned}
$$

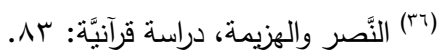

$$
\begin{aligned}
& \text { rol/ البقرة) (rv) } \\
& \text { (الفتح/ (r^) }
\end{aligned}
$$

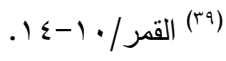

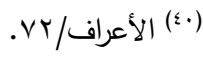

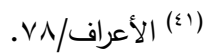

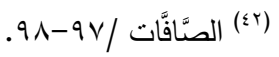

$$
\begin{aligned}
& \text { rON/ البقرة) }
\end{aligned}
$$

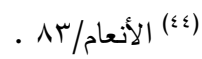

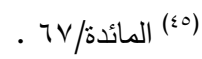

$$
\begin{aligned}
& \text { (iv) }
\end{aligned}
$$

|lv| ينظر : الجهاد طريق النَّصر / (vv) 


$$
\begin{aligned}
& \text { (1) }
\end{aligned}
$$

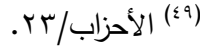

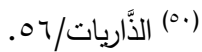

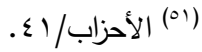

$$
\begin{aligned}
& \text { ( ) - (or) } \\
& \text { ( النّّساء/ (or) }
\end{aligned}
$$

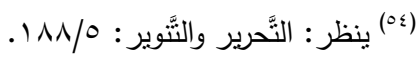

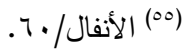

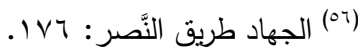

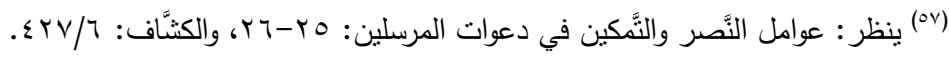

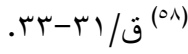

$$
\begin{aligned}
& \text {.101/ الأنعام/(109) } \\
& \text {. } 1-V /(7 \cdot)
\end{aligned}
$$

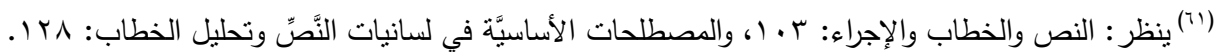

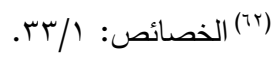

(1)

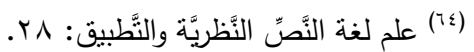

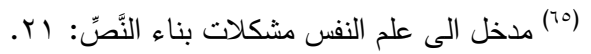

101)

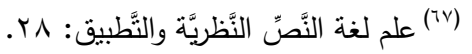

(1^)

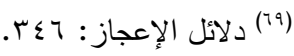

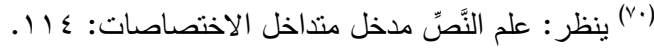

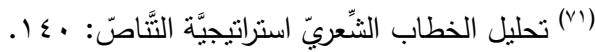

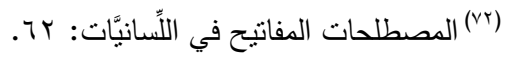

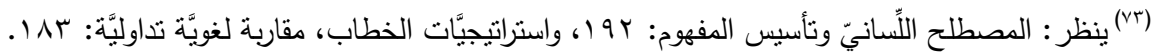

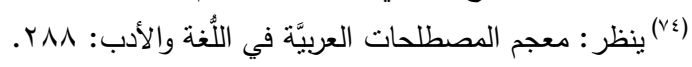

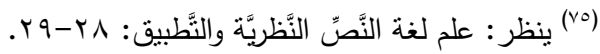

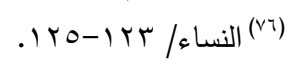




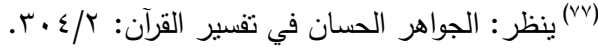

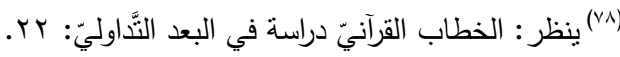

$$
\begin{aligned}
& \text { (v9) المائدة/79/ (v9) }
\end{aligned}
$$

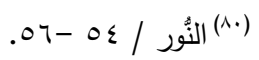

(N)

$$
\text { (Ar) }
$$

9 ينظر : الإعجاز في نسق القرآن:

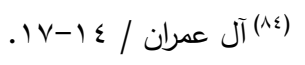

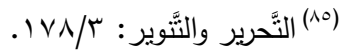

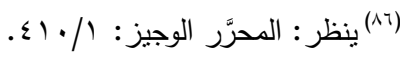

$$
\text { 90/ النّّساء (Av) }
$$

. التَّبة//11)

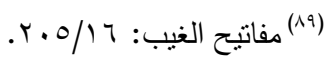

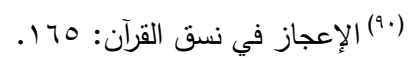

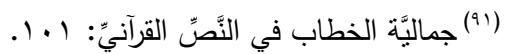

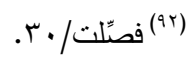

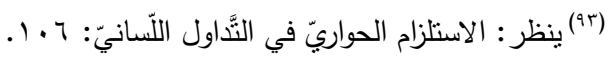

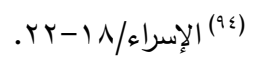

(90) في لسانيَّات النّصِّ وتحليل الخطاب:

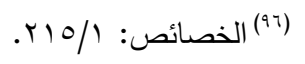

ا الأنفال (9v)

(9^)

. 1 / الغانشية / (199)

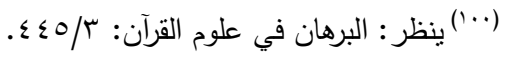

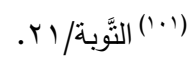

$$
\text { (r) }
$$

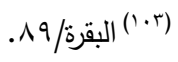

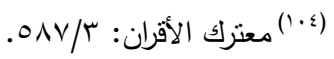

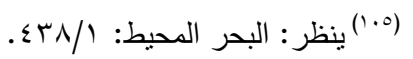




$$
\begin{aligned}
& \text { (T-1) الأنفال/r. }
\end{aligned}
$$

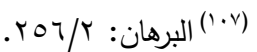

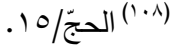

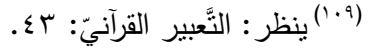

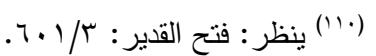

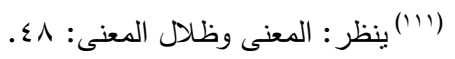

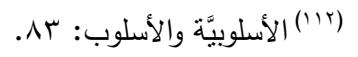

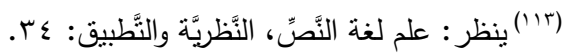

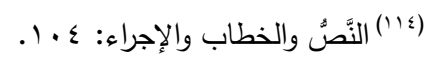

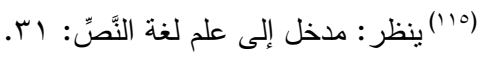

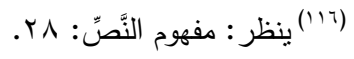

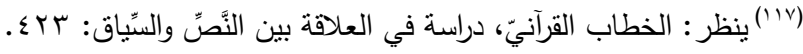

$$
\text { (1). (11) }
$$

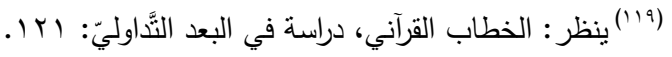

$$
\text { . } 7 \text { r/ }
$$

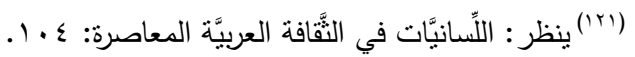

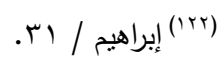

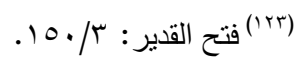

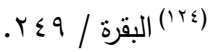

$$
\text { (ro) }
$$

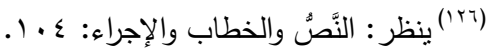

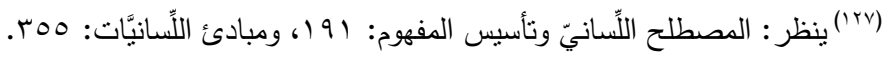

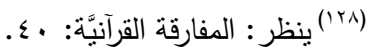

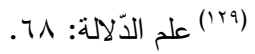

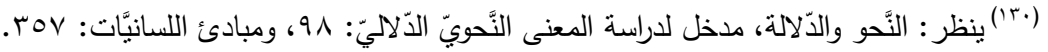

$$
\text { (ا) }
$$

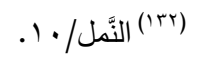

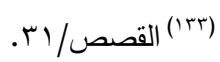

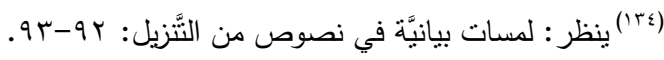




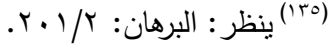

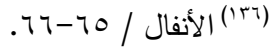

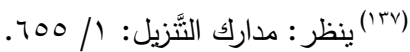

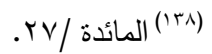

$$
\begin{aligned}
& \text { (1\%9) }
\end{aligned}
$$

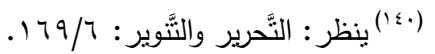

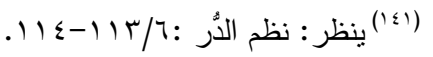

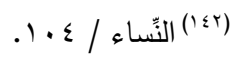

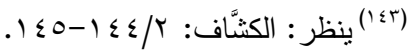

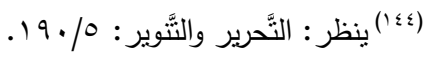

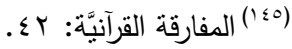

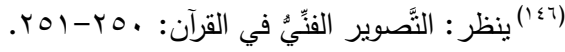

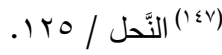

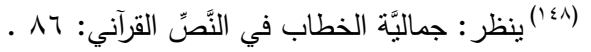

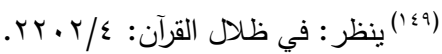

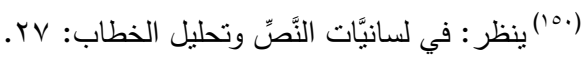

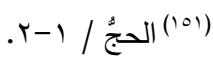

$$
\begin{aligned}
& \text { ينظر : البحر المحيط: (10r) } \\
& \text { (10r) }
\end{aligned}
$$

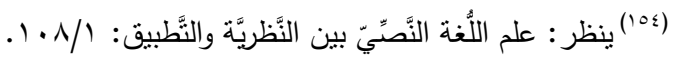

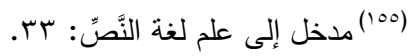

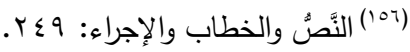

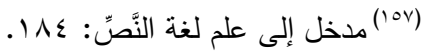

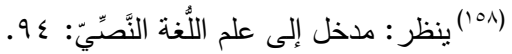

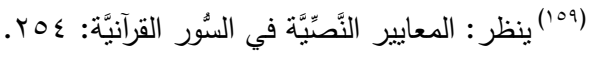

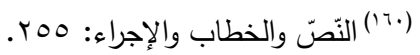

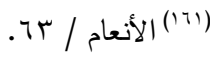

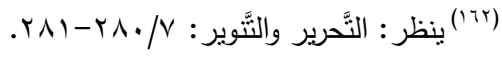

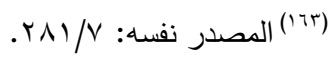




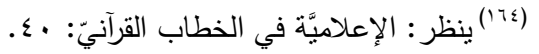

$$
\text { (القصص/ }
$$

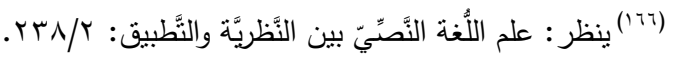

$$
\text { (1) (17\%) }
$$

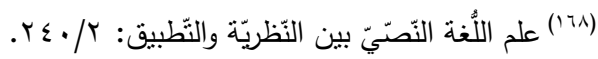

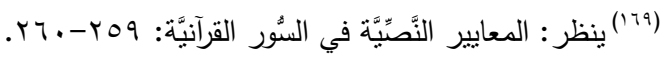

$$
\text { . VV / البقرة (IV.) }
$$

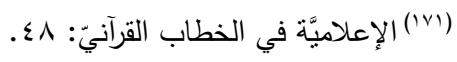

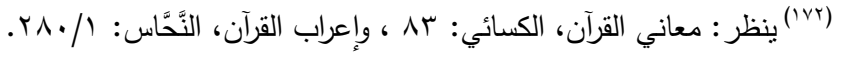

$$
\text { .09/ / الحجر (1Vr) }
$$

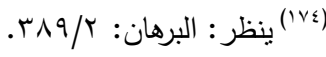

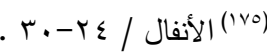

$$
\text { (1V) }
$$

(1vv)

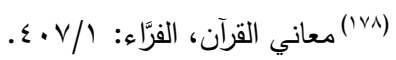

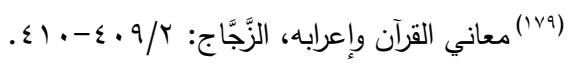

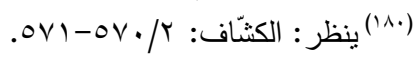

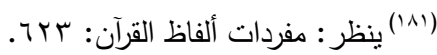

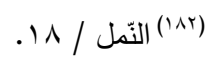

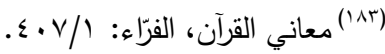

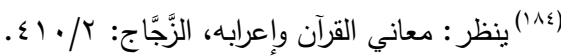

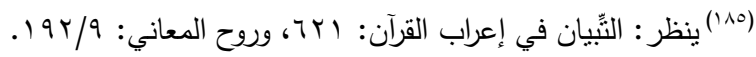

(TA1) هنالك الكثير من التَّويلات والأعاريب لهذه الآية الكريمة، قد فصَّل القول فيها الآلوسي، ينظر : روح المعاني:

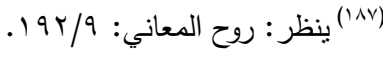

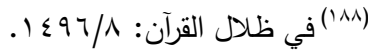

$$
\begin{aligned}
& \text { 190/9: روح المعاني }
\end{aligned}
$$

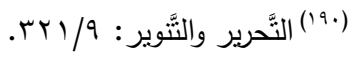

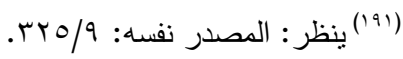

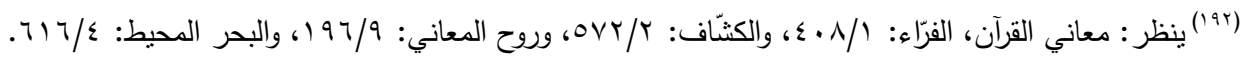




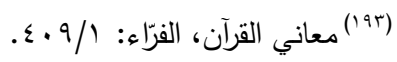

(9\&) (19) (19ظر : الإعلاميَّة في الخطاب القرآني:

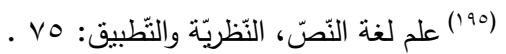

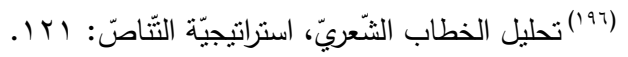

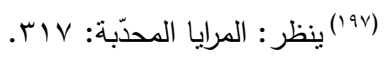

$$
\text { (19人) }
$$

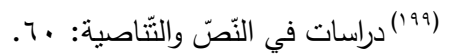

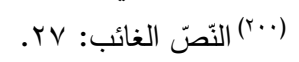

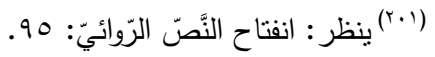

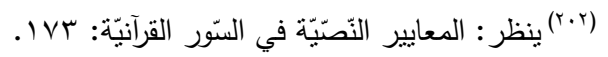

$$
\begin{aligned}
& \text {.90/. } 90 / \text { (r) }
\end{aligned}
$$

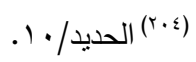

(أضواء البيان: (r.0)

$$
\text { ( النّاء/r.T) }
$$

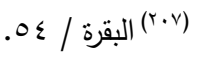

(r.ᄉ)

$$
\text { (r.9) }
$$

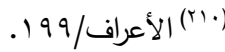

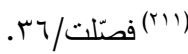

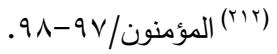

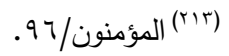

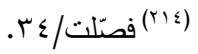

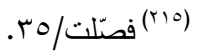

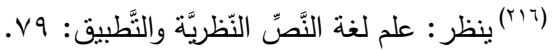

$$
\begin{aligned}
& \text { (Y) الأعراف/Tr) (YT) } \\
& \text { (r) يونس/r) } \\
& \text { } \\
& \text { (Yr.) } \\
& \text { (القمر/rr) }
\end{aligned}
$$




$$
\begin{aligned}
& \text { (المؤمنون/r) } \\
& \text {. }
\end{aligned}
$$

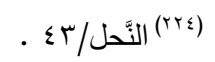

$$
\begin{aligned}
& \text { r ( الفرقان/(rro) } \\
& \text { (rT) } \\
& \text { (rr) }
\end{aligned}
$$

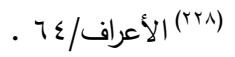

$$
\begin{aligned}
& \text {.11/ القمراف/(rqa) }
\end{aligned}
$$

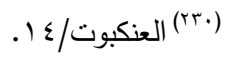

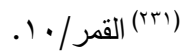

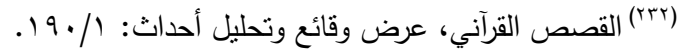$$
\text { (10 الإعبrr) }
$$

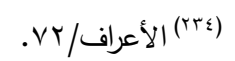$$
\text { ( أضواء البيان: (rro) }
$$$$
\text { ( T) }
$$

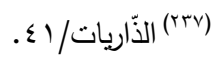$$
\text { . VV/الأعراف/(rrs) }
$$

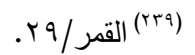$$
\text { . VV/ الأعراف/Y\&.) }
$$

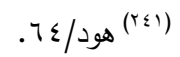$$
\text { .70/دو هود (YST) }
$$

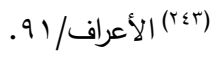$$
\text { (Y ) هود/T\&) }
$$

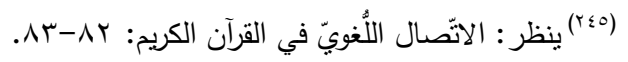$$
\text { . VT/ V الأعراف }
$$ 